Bureau d'Économie

Théorique et Appliquée BETA

www.beta-umr7522.fr

@beta economics

Contact :

jaoulgrammare@beta-cnrs.unistra.fr

\section{«Exploring the Puzzle of Human Reproduction: Register Data based Evidence from France and Germany»}

\author{
$\underline{\text { Auteurs }}$ \\ Cäcilia Lipowski, Ralf A. Wilke, Bertrand Koebel
}

Document de Travail $n^{\circ} 2020-24$

Mai 2020 


\title{
Exploring the Puzzle of Human Reproduction: Register Data based Evidence from France and
}

\author{
Germany *
}

Cäcilia Lipowski ${ }^{\dagger}$

Ralf A. Wilke

Bertrand Koebel ${ }^{\S}$

May 11, 2020

\begin{abstract}
Birth rates differ strongly across European states, despite the deep economic harmonisation process related to European integration. This study uses large scale administrative data from France and Germany to analyse and directly compare fertility patterns in two major European economies over a period of 15 years. Strong evidence is found that opportunity costs play a role in fertility decisions, and for a positive income effect for females with high earnings. Females in Germany adapt their fertility behaviour more strongly in response to economic incentives than their counterparts in France. This is explained by pronounced differences in the national approaches to childcare support.
\end{abstract}

Keywords: family policy, fertility behaviour, count data, panel data JEL: J13, J11, C23, C25

*This work is supported by the French National Research Agency (ANR) as part of the "Investissements d'avenir" program (ref: ANR-10-EQPX-17-Centre d'accès sécurisé aux données - CASD) and the "FamPol" project (ref: ANR-10-EQPX-17). The costs for the data access were borne by the ZEW Mannheim. We thank François Laisney, Vincent Vergnat, Melanie Arntz and Isabelle Terraz for helpful feedback.

$\dagger$ ZEW Mannheim, email: caecilia.lipowski@zew.de

${ }^{\ddagger}$ Copenhagen Business School, Department of Economics, and ZEW Mannheim, email: rw.eco@cbs.dk

§Université de Strasbourg, Université de Lorraine, AgroParisTech, CNRS, INRAE, BETA Strasbourg, email: koebel@unistra.fr 


\section{Introduction}

All countries of the European Union exhibited fertility rates below replacement level in 2017 (World Bank 2019a). This fact demonstrates the difficulty for family policies in industrialised countries to achieve their main objectives: increase birth rates and conciliate childbirth and labour market participation. In order to set the right incentives, it is of eminent importance for policy makers to understand fertility behaviour and its relation to labour market decisions in the context of country-specific settings. In this study, we present a comparative micro-level analysis of fertility in two major European countries, namely France and Germany for the years 1994 to 2007. These countries are characterised by substantial differences in fertility (Figure 1), female labour force participation (Figure 2) and institutional settings. During the relevant period, France has a quite stable birth rate, among the highest in the European Union, while Germany is characterised by a low and declining birth rate. Until the mid 2000's, French family policies have mainly targeted the compatibility of full-time work with having children by providing various types of childcare services. At the same time, Germany has stuck to the male breadwinner model, granting financial compensation to mothers rearing children at home. The empirical literature evaluating the effectiveness of family policies on a macro level provides evidence that family policies investing in a better work-family conciliation are more effective at raising fertility rates than those providing financial assistance to parents (Hantrais, 2004; McDonald, 2006; Gauthier, 2007).

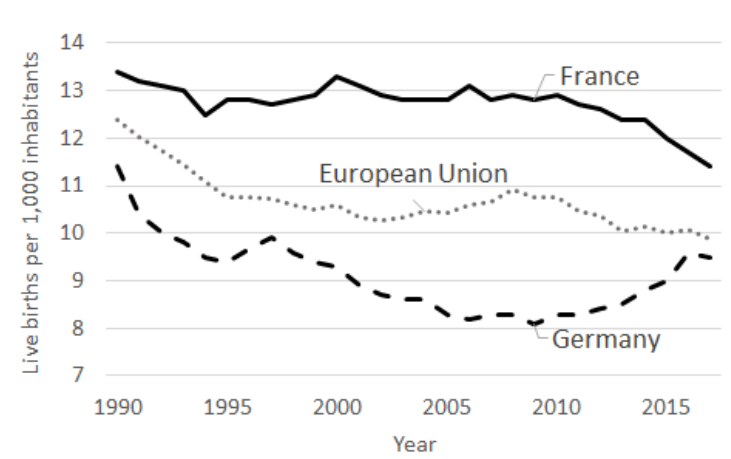

Figure 1: Average birth rates. Source: World Bank 2019b.

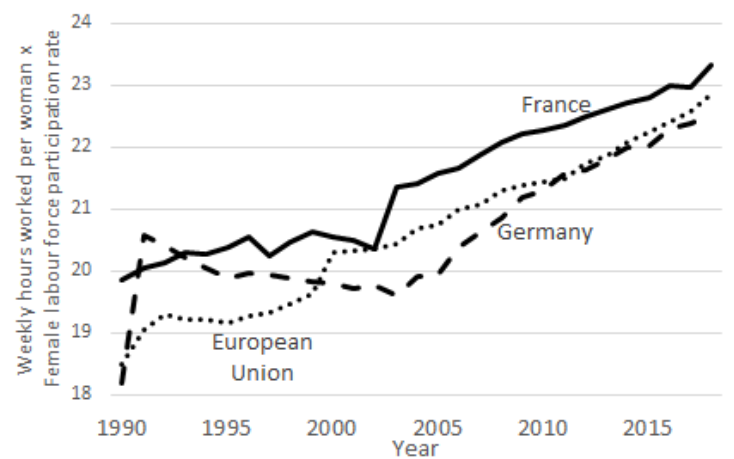

Figure 2: Average weekly hours worked per dependently employed woman $\times$ female labour force participation rate.

Source: OECD 2019a and OECD 2019b.

Most of the existing empirical literature on fertility behaviour either focuses on country 
comparisons with aggregate data (e.g. Ahn and Mira, 2002; Adsera, 2004; Billari and Kohler, 2004) or uses individual-level data from only one country (e.g. Heckman and Walker, 1990; Winkelmann and Zimmermann, 1994; Wang and Famoye, 1997, Francesconi, 2002; Adda et al., 2017). Cross-country analyses with individual-level data are limited and rely on rather small survey data sets (e.g. Lauer and Weber, 2003; Del Boca and Sauer, 2009). Interestingly, the empirical results obtained from macro and micro data seem contradictory. Micro-level studies find empirical evidence of a negative effect of female wages and labour market attachment on fertility due to high opportunity costs (Heckman and Walker, 1990; Winkelmann and Zimmermann, 1994; Caudill and Mixon, 1995; Wang and Famoye, 1997; Francesconi, 2002; Baudin et al., 2015; Adda et al., 2017). Macro studies focusing on crosscountry differences find a positive relationship: countries with high female labour force participation rates tend to exhibit higher levels of fertility (Brewster and Rindfuss, 2000; Ahn and Mira, 2002; Billari and Kohler, 2004; Adsera, 2004, all for the time period between the 1970s and 1990s). The empirical findings regarding the relationship between employment and fertility are therefore ambiguous, and depend on whether evidence comes from a given country, or from comparing two countries. Our objective is to study this paradox by using data with both individual and country-level dimensions.

This paper presents a pioneering cross-country analysis of fertility behaviour of French and German women based on large scale linked administrative panel data for the two countries. In particular, we use the French DADS-EDP and German BASiD datasets. As these data sources result from national operational processes, we made substantial efforts in creating comparable data sets for the two countries. Besides presenting a number of new comparative stylised facts, we estimate econometric panel count models for fertility behaviour at the individual level. These models exploit the individual employment histories and allow for forms of endogeneity that arise from omitted variables and simultaneity in decision making. To our knowledge, previous analyses of fertility have mainly not been based on panel analysis. Winkelmann and Zimmermann (1994), Silva and Covas (2000) and Melkersson and Rooth (2000), all using count data models, consider only the number of children at the end of the reproductive cycle instead of the number of children evolving over time. Wang and Famoye (1997) only pick one wave of data and Caudill and Mixon (1995) simply neglect the panel structure. Del Boca (2002) estimates a binary panel model of fertility in Italy. We are only aware of one related cross-sectional study for the two countries: 
Lauer and Weber (2003) use household survey data but focus on labour force participation after childbirth. By doing a pooled cross-sectional analysis they do not exploit the panel structure of their data to address endogeneities.

We obtain a number of interesting findings. We confirm the hypotheses derived from an economic model and previous empirical evidence concerning cross-country and withincountry relationships between female opportunity costs and fertility. Regarding both timing of births and total fertility, we find that responses to opportunity costs are more pronounced in Germany than in France. For both countries, we find a positive effect of female wages on the number of children for women with the highest wages. Since the only source of household income considered in this paper is female wage, we use income and wage interchangeably.

The structure of this paper is as follows: Section 2 compares the contextual settings of France and Germany. Section 3 states the main economic hypotheses to be analysed, while Section 4 presents the data sets and some stylised facts. The econometric model is presented in Section 5 and the main estimation results are given in Section 6. Section 7 concludes.

\section{Family Policies in France and Germany}

Systematic differences in fertility behaviour between French and German women are likely due to different historical and cultural backgrounds, social conventions and resulting family policies. Here we focus on the period 1994 to 2007. While there was still a strong historical attachment to the male breadwinner model in Germany, the French state provided support and incentives for young mothers to return to the labour market quickly. Besides the goal of reconciling work and family life, the French system promoted families of three or more children. In contrast, Germany did not encourage young mothers to return to work nor favoured large families but supported child-rearing at home with cash benefits. In the following, we briefly compare the different national childcare arrangements, child-rearing benefits and aggregated transfers during the aforementioned period.

A - Childcare The French transition from the male breadwinner model to the dual model began in the 1970s, following a sharp rise in women entering the work force. In Germany, a slow abandonment of the male breadwinner model only started in the 1990s with a policy-induced expansion of childcare places for children between three and six years old. 
However, measures to support French working parents were expanded at the same time, resulting in a persistent gap in childcare provision between both countries (Fagnani, 2010). For instance, the French government began to subsidise registered private childminders in the 1990s. Unlike in France, the German approach to childcare was characterised by a shortage of childcare places for children below the age of six, a late entry into daycare and an incompatibility between the regular working hours of parents and the opening hours of day care institutions. For more details on these policies see Brewster and Rindfuss (2000), Plantenga et al. (2005), Lewis et al. (2008), Fagnani and Math (2010) and Salles et al. (2010). Plantenga et al. (2005) suggest that the childcare coverage rate for children under three was only $8 \%$ in Germany in contrast to $43 \%$ in France in 2004 . For children aged three to six, the difference was lower thanks to the above-mentioned transformation process: $89 \%$ in Germany compared to full coverage in France. Due to this low supply of childcare places in conjunction with traditional gender roles, it was more difficult for mothers in Germany to return to paid work. OECD data confirm these patterns: while both countries spent similar percentages of GDP on family cash benefits between 1994 and 2007, government expenditure on family services was approximately twice as high in France as in Germany (OECD 2019c). In addition, expenditure on childcare and education was between 1.8 and 3.6 times higher in France than in Germany.

Salles et al. (2010) explain these fundamental differences by a historical long-term trend. The German standards are claimed to have been formed in response to the National Socialism and the Communism, by focusing on the families and giving public institutions a minor role. In contrast, essential features of the French family policy were formed during the late $19^{\text {th }}$ century as an attempt to limit the power of the church by intervening in citizen's private lives.

By the end of the observation period, Germany started a reform process which was accompanied by an increase in fertility. In particular, Germany began to promote female employment and to invest in public childcare (Fagnani and Math, 2010). Bauernschuster et al. (2016) have shown that the expansion of public child care in Germany caused an increase in fertility rates.

B - Child-rearing benefit Another important difference between the two countries was in paid parental leave arrangements, as summarised in Table A.1 in the Appendix. These 
benefits were meant to partially compensate earnings losses due to child-rearing. In both countries, child-rearing benefits were lump-sum amounts and having an additional child during the benefit reception period renewed the eligibility duration. Here, the French aim to encourage large families was particularly visible: the French Allocation parentale d'éducation (APE) was initially provided to parents of at least three children, extended to parents of two children in 1994 and was replaced by the Complément de libre choix d'activité (CLCA) in 2004. The CLCA was also accessible for parents of one child, but only for a short time period. Piketty (2005) estimates that up to $30 \%$ of the French increase in births between 1994 and 2001 was due to the extension of the APE to mothers of two children. The German Erziehungsgeld (1986-2007) was provided from the first child on and did not vary with the number of children. The Erziehungsgeld did not impose any conditions in regard to past labour performance. Conversely, a French parent needed to have worked for at least two years preceding birth, creating some form of labour market attachment. In addition to the APE, French parents received a means-tested basic allowance until the child was three years old. This benefit was independent of the employment decision. The German childrearing benefit encouraged part-time work: exercising a part-time job did not reduce the Erziehungsgeld whereas the amount of APE was halved when working part-time.

Traditions in work-family conciliation and the availability of childcare seem to play an important role: Plantenga et al. (2005) show that the take-up rate of the child-rearing benefit was $85 \%$ in Germany. In France, less than half of the entitled French households received the child-rearing benefit. French recipients were mainly young, unemployed or low paid women (Morel, 2007; Algava et al., 2005; Piketty, 2005). In short, in France the APE plus the basic allowance encouraged mainly low-paid or unemployed women to become pregnant, favoured large families but did not affect much female labour force participation. In Germany, the Erziehungsgeld in combination with a shortage of childcare places did not encourage mothers to oppose tradition and carry out full-time work, but to raise their children at home, which has been linked to lower fertility levels (Brewster and Rindfuss, 2000; Ahn and Mira, 2002; Billari and Kohler, 2004; Adsera, 2004).

C - Aggregate incentives set by tax breaks and social benefits In order to comprehensively compare financial and institutional settings, additional policy measures need to be taken into account. In Germany, until the child turned 27, parents received either a 
child cash benefit (Kindergeld) or a child tax allowance (Kinderfreibetrag), depending on what was more beneficial for the parents. Both measures became slightly more generous as the number of children increased. In France, until the child turned 20, parents received both a child benefit (Allocations familiales) and an income tax reduction realised by raising the quotient by which the taxable income was divided before taxation took place (Quotient familial). For the first and second child, the divisor by which the taxable income was divided increased from 2 to 2.5 for a couple, for the third and every subsequent child by one (with a maximum ceiling). The French child benefit also increased with the number of children but started only from the second child onward. In addition, there was an income-tested supplement (Complément familial) for the third and every subsequent child. Baclet et al. (2005) combine the incentives set by the income tax, the child cash benefits and the child tax reductions to a so-called effective tax rate. For both countries they find that the effective tax rate decreases with the number of children. The evolution of the effective tax rate with income differs between both countries: for households earnings below a certain threshold, the effective tax rate is lower in Germany than in France. For pre-tax incomes greater than 36.000 - 45.000 Euros (depending on the marital status and the number of children), however, the German effective tax rate is above the French effective tax rate.

For a more complete picture, social assistance and housing benefits also need to be taken into account. The resulting aggregate transfers in France are U-shaped in family income: on the one hand, low-income families gain relative to median earners due to the means test

for the basic allowance of the early childhood benefit. On the other hand, high-income families benefit from the quotient familial (Bechtel et al., 2005). Adema and Thévenon (2008) expand the French study to other OECD countries. They find that transfers in Germany are almost constant in household income and increase modestly for high incomes.

\section{Economic Mechanisms and Hypotheses}

This section briefly summarises the economic mechanisms behind the female decision problem of the optimal number of children and and their testable implications. The optimal number of children results from a timewise separable economic model of utility maximisation, which is presented in the supplementary material S.I. While the optimal number of children is assumed to be the solution to the same mathematical problem in both countries, 
the parameters are permitted to differ between countries to capture the cultural and institutional differences between France and Germany. We derive two main economic hypotheses focusing on these cross-country differences that are subsequently tested with data.

1 - Opportunity costs: numerous and flexible childcare arrangements in France reduce the opportunity costs of having a child in terms of foregone wages, career impediment and skill depreciation. In contrast, a weaker family-work conciliation in Germany increases the opportunity cost of children. This leads us to the hypothesis that within both countries the optimal number of children decreases with (full-time) employment, education and wage, and that these partial relationships are more pronounced in Germany than in France. Putting this in the context of the macro literature on labour supply and fertility, we claim that the country with higher female labour force participation rates (France) exhibits higher fertility rates than the country with lower female labour force participation rates (Germany) because of lower opportunity costs due to a better conciliation of family and professional life.

2 - Effective tax reduction: as pointed out in Section 2, for both countries the effective tax rate decreases with the number of children. At high levels of income, this tax reduction is larger in France than in Germany. In addition to average tax reduction, the French promotion of large families also increases the marginal effective tax reduction per each additional child. Integrating these features into our economic model implies two hypotheses: firstly, we expect a relative increase in fertility at high levels of income in both countries. Together with the negative opportunity costs of having children this translates into a Ushaped pattern in the effect of wages on fertility. Secondly, we conjecture that the positive effect for high wages is more pronounced in France than in Germany. For high-earning French women, the negative opportunity costs might even be outweighed by the reduction in the effective tax rate.

The next section describes the data used to test our hypotheses and provides some first descriptive results.

\section{Data and Stylised Facts}

We construct comparable samples from two administrative data sources for the two countries. This is a non-trivial exercise given that these data sources differ substantially in shape and content as they are collected through different processes. In this section we provide a 
brief overview of how this comparability is achieved and present first stylised facts. More details on the data preparation and descriptive statistics are given in Appendix A.II.

The German Biographical Data of Selected Social Security Agencies in Germany (BASiD) links administrative individual-level data from the Federal Employment Agency and the Institute for Employment Research to data from the German Pension Insurance. ${ }^{1}$ The pension insurance covers $96 \%$ of the German population, from which a $1 \%$ random sample is made available via the BASiD. The dataset encompasses individuals up to the age of 67 who held an insurance account at the end of 2007, provided that they had at least one entry and that they were still alive. Periods of employment, training measures, registered unemployment and certain types of inactivity are reported with exact dates. Furthermore, the database provides information on average daily salary, occupation, type of employment (full-time versus part-time), characteristics of the employing firm and demographic information such as gender, age, educational achievements and dates of birth for any children.

The French panel Déclaration Annuelle des Données Sociales - Echantillon Démographique Permanent, 2010 (DADS-EDP 2010) contains socio-demographic information of individuals observed in the EDP combined with administrative employment data from the DADS since 1976. Drawing its information from civil registers and the census, the EDP contains details on education, marriage and fertility. Only persons born from the $1^{\text {st }}$ to the $4^{\text {th }}$ of October of each year are followed. Since 2004 the dataset is enriched by individuals born from the $1^{\text {st }}$ to the $4^{\text {th }}$ of April and July. The information in the DADS stems from mandatory declarations completed by all businesses with dependently employed staff. It comprises data on start and end dates of employment, wages, hours worked, types of contract and occupation. Self-employed, civil servants and individuals that have never been employed do not appear in this data. Since 2004, persons living in French overseas territories have been included, whereas before 2004 only continental France was considered.

The French dataset is more selective than the German dataset in terms of individuals included and periods recorded: the DADS-EDP exclusively encompasses persons with at least one record of non-self-employed work, whereas the BASiD also covers individuals that have never been dependently employed but were observed by the Federal Employment Agency or the Pension Insurance for a different reason, for example due to voluntarily insured selfemployment or the eligibility for minimum income support. Selection into these datasets

\footnotetext{
${ }^{1}$ Detailed information on the dataset can be found in Hochfellner et al. (2011).
} 
is therefore not entirely random and might hereby induce biases for our country-specific estimates. Individual employment histories are less complete in the French data than in the German data because the former exclusively contain periods of dependent employment. This restriction affects the set of explanatory variables included in the comparative two-country analysis as the current and past labour market states likely affect fertility behaviour. Unfortunately, no information on marital status and hence on a potential partner is recorded in the BASiD. The French dataset contains the date of marriage but without current updates on marital status nor information on the spouse. Information on personal preferences, religion or social conventions is not provided in any of the data sources. We will exploit the longitudinal dimension of the data to address the omission of important variables. The precision of our analysis benefits from the large cross-sectional and longitudinal data dimensions that are not available with survey data. Furthermore, errors due to misstatements in the birth and employment variables are unlikely since they are key variables of administrative records.

We construct comparable annual panel datasets for the period 1994 to 2007 for the two countries. The panels are based on employment records of women aged between 18 to 45 in the respective years. For a detailed description of the data preparation and the harmonisation of the data sets see Appendix A.II. In both samples, a woman is observed for at least one and at most 14 years. The German panel contains 173,843 females, the French panel 102,574. When we construct aggregate birth rates from the BASiD and the DADSEDP, they are somewhat lower than the birth rates reported by the national statistical institutes, even when not restricting the dataset. This could be caused by the selectivity of the datasets or by unregistered births, which probably occurred after the last observed record. Descriptive statistics of the independent variables and the estimation samples are given in Table A.2 in the Appendix.

The remainder of this section provides a descriptive analysis of fertility in the two countries. Table 1 presents the average completed fertility rates by age cohort, education and country. No numbers are reported for the youngest birth cohort (born between 1979 and 1989) since the maximum age they can reach in the data is 28 years. The table confirms that birth rates are higher in France for all cohorts and educational groups. A French woman aged 45 has on average at least 0.5 children more than a German woman of the same age, which is sizeable. Females in the third birth cohort are aged between 38 and 47 in 2007 . 
Even though not all of the females belonging to this cohort have reached the end of their reproductive life at the end of the observation period, most have. French women of this cohort have on average twice as many children as their German equivalents. This number is in line with our hypothesis about different economic incentives in Germany and France.

Table 1: Average number of children per cohort and education

\begin{tabular}{l|lll|lll|lll|lll}
\hline \hline & \multicolumn{3}{|c}{ Cohorts } & \multicolumn{3}{c}{ Cohort I } & \multicolumn{3}{c}{ Cohort II } & \multicolumn{3}{c}{ Cohort III } \\
& I & II & III & No VT & VT & TE & No VT & VT & TE & No VT & VT & TE \\
\cline { 2 - 12 } $\mathrm{G}$ & 1.47 & 1.19 & .67 & 1.59 & 1.46 & 1.26 & 1.24 & 1.23 & .91 & .75 & .71 & .37 \\
$\mathrm{~F}$ & 1.97 & 1.82 & 1.27 & 2.19 & 1.96 & 1.77 & 1.91 & 1.85 & 1.70 & 1.43 & 1.30 & 1.18 \\
$\Delta$ & .50 & .63 & .60 & .60 & .50 & .51 & .67 & .62 & .79 & .68 & .59 & .81 \\
\hline \hline
\end{tabular}

Notes: Completed fertility at age 45 or last observed age if not available. Cohort I: born 1949-58, Cohort II: born 1959-68, Cohort III: born 1969-78. VT=Vocational Training, TE=Tertiary Education, $\mathrm{G}=$ Germany, $\mathrm{F}=$ France, $\Delta=$ Difference between France and Germany.

Table 2 digs a bit deeper into the formation of the completed average birth rates. It suggests that the lower average in Germany is driven by both a higher share of childless women and a lower share of women with two or more children. For the two birth cohorts with completed fertility, the share of childless women in Germany is around twice as high as in France. The German pattern sizeably changes over cohorts: the share of German women remaining childless more than doubles between the first and the third cohort, while the share of German mothers of two children more than halves. Sobotka and Beaujouan (2014) refute the potential explanation that a fading two-child norm has caused this drop. They find a stable ideal family size of more than two children for (West) Germany for the entire period from 1979 to 2011. Our results, however, suggest that actual figures deviated increasingly from desired outcomes. In France, the share of childless women also doubled over cohorts but the share of women having two children remained nearly constant. In France, the decrease in the share of women having three or more children is remarkable: for the first birth cohort the share was around $30 \%$, for the third only $11 \%$.

It is also apparent from the two tables, that the average number of children varies strongly with the mother's level of education. In particular, females with a higher level of education tend to have fewer children. This is considered in more detail in the following two paragraphs. 
Table 2: Share of women by number of children, by cohort or education in $\%$

\begin{tabular}{c|cc|cc|cc||cc|cc|cc}
\hline \hline & \multicolumn{2}{|c}{ Cohort I } & \multicolumn{2}{c}{ Cohort II } & \multicolumn{2}{c}{ Cohort III } & \multicolumn{2}{c}{ No VT } & \multicolumn{3}{c}{ VT } & \multicolumn{2}{c}{ TE } \\
& G & F & G & F & G & F & G & F & G & F & G & F \\
\hline 0 & 24.7 & 13.5 & 35.4 & 16.7 & 56.9 & 30.3 & 42.4 & 16.8 & 40.1 & 20.0 & 60.9 & 27.0 \\
1 & 24.3 & 20.7 & 25.2 & 19.9 & 24.4 & 26.2 & 26.2 & 22.1 & 25.8 & 22.8 & 16.1 & 22.5 \\
2 & 36.1 & 36.6 & 28.3 & 39.0 & 14.5 & 32.3 & 19.5 & 37.3 & 25.5 & 35.8 & 18.4 & 35.2 \\
3 & 11.3 & 19.8 & 8.4 & 17.6 & 3.4 & 9.2 & 8.2 & 16.7 & 6.7 & 15.4 & 4.0 & 12.1 \\
$4+$ & 3.7 & 9.4 & 2.7 & 6.8 & 0.8 & 2.1 & 2.9 & 7.2 & 1.9 & 6.1 & 0.7 & 3.2 \\
\hline \hline
\end{tabular}

Notes: Completed fertility at age 45 or last observed age if not available. Cohort I: born 1949-58, Cohort II: born 1959-68, Cohort III: born 1969-78. VT=Vocational Training, TE=Tertiary Education, $\mathrm{G}=$ Germany, $\mathrm{F}=$ France.

B - Number of Children by Education Table 1 suggests that for any educational group, women in France have, on average, more children than women in Germany. The between country difference in the average number of children $(\Delta)$ is U-shaped in the level of formal education: the difference is most pronounced for high and low-educated females, and is smaller for those with vocational training. The U-shaped pattern may be caused by high opportunity costs for German university graduates or by the likewise U-shaped design of the French aggregated monetary benefits distributed to parents, see Section 2. For each educational group, the share of childless women in Germany is more than twice as high as the share of childless women in France (Table 2). In line with patterns found by Baudin et al. (2015) for the US, the distribution of childlessness by educational degree is J-shaped in Germany. In France, childlessness is constantly increasing with educational degree. These findings also point into the direction of particularly pronounced opportunity costs for females in Germany with a tertiary education degree and females in France with the medium educational level.

In France, the propensity to have two children is extremely pronounced for all educational groups. For low, middle and highly educated women, the share of mothers of two children is more than 1.5 times the share of mothers of a single child. In Germany, highly educated mothers seem to respond most to the two-child norm, and low educated mothers least.

C - Number of Children by Age Figure 3 focuses on age at first birth depending on education. To measure the share of females in the presence of censoring, we use the KaplanMeier estimator. This simple non-parametric estimate of a fraction takes into account that not all females reach the age of 45 years. In the German case, the age distribution becomes 

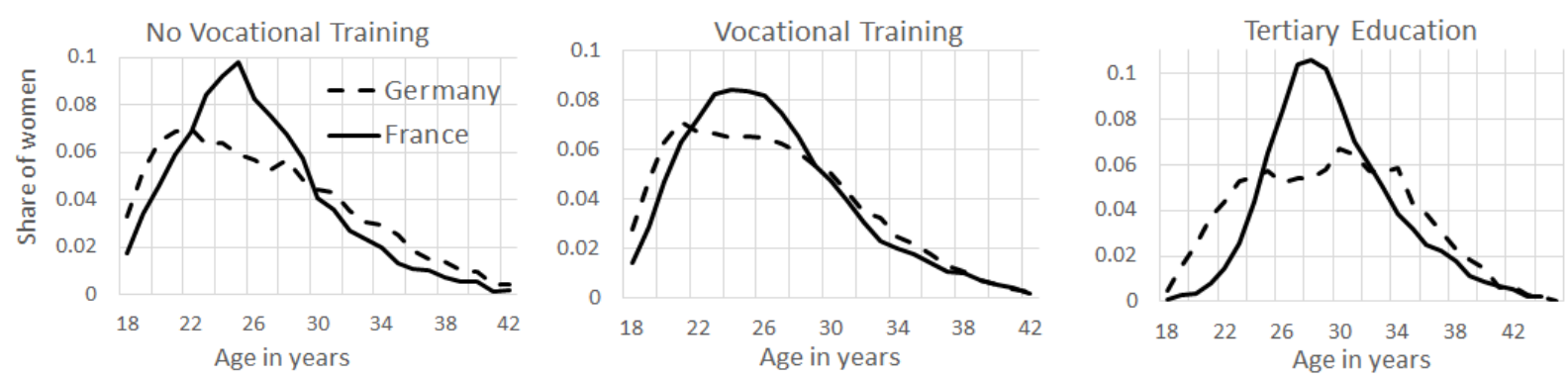

Figure 3: Age at first birth per educational level

Notes: Share of mothers by age and educational level at first birth. Kaplan-Meier Product Limit estimator.

less bell-shaped with higher educational attainment. In contrast, the distribution exhibits a bell-shape for any level of education in France. The cross-country differences for women with tertiary education are striking: below 25 years and above 33 years, the percentages of women having their first child are slightly higher in Germany than in France. For the ages in between, the share is much higher in France than in Germany. Apparently, females in Germany that hold a university degree tend to either shift forward or postpone their first birth. This could be in order to not interfere with their initial years in the labour market. French women seem to combine career and childbearing as the distribution is narrowly centred around the peak at age 28, shortly after labour market entry. In Germany, these curves also become flatter with birth cohorts (Figure 4). In contrast to older cohorts, the age distribution for German women of the third cohort exhibits a relatively flat maximum between the age of 25 and 32. This may partly but not entirely be due to the fact that the share of women who have studied increased by five percentage points from the first to the third cohort. This flattening of the age distribution indicates that German women born later face difficulties to combine work and family. In contrast, the shape of the French distribution does not change much over cohorts. Only the peak shifts from 23 years for the first to 28 years for the third birth cohort. Overall, being older when having the first child seems to have become more beneficial or more common in both countries.
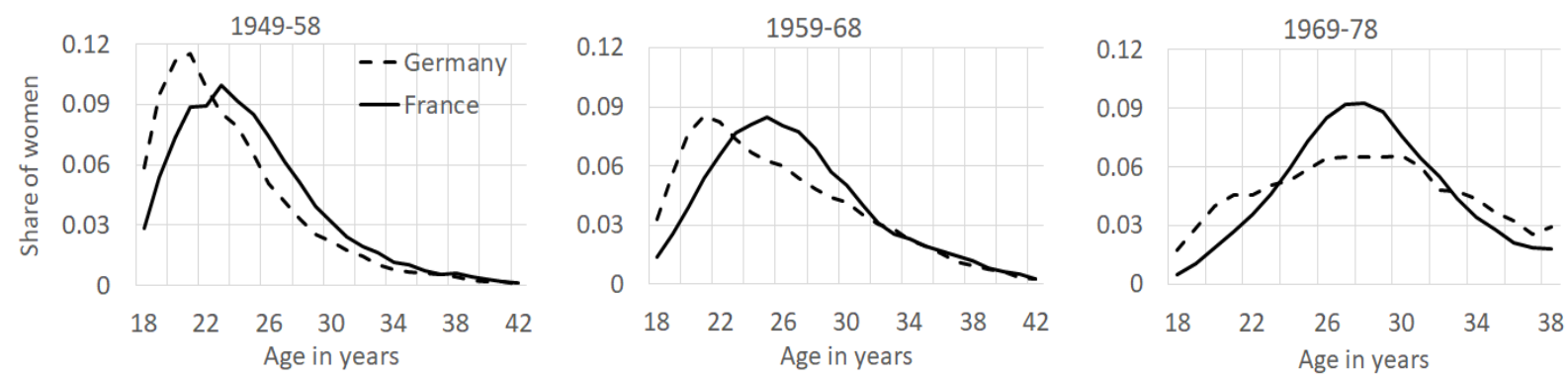

Figure 4: Age at first birth per cohort

Notes: Share of mothers by age and birth cohort at first birth. Kaplan-Meier Product Limit estimator. 
D - Labour Market State and Tenure We complete the descriptive analysis by considering the relationship between fertility, the current labour market state and the length of current employment duration. Table 3 shows the share of females giving birth to a child while being non-employed. For the first child, the share is similar in both countries: $47 \%$ of all German females and $45 \%$ of all French females who give birth to a first child do so while being non-employed. In France, the percentage increases modestly for the second and the third child. In contrast, the increase for the second and the third child is much more pronounced in Germany.

Table 3: Births during non-employment

\begin{tabular}{l|ccc}
\hline \hline & 1st child & 2nd child & 3rd child \\
\hline Germany & 47 & 65 & 74 \\
France & 45 & 48 & 58 \\
\hline
\end{tabular}

Notes: Share of women having their first, second or third child while being non-employed in \%.

The comparatively low share of births during non-employment for the second and third child in France may indicate that well-functioning childcare arrangements allow French women to refrain from fully withdrawing their labour when having a child, and from squeezing multiple births into the same period of inactivity. This supports the findings by Rodrigues and Vergnat (2018). In contrast, mothers in Germany seem more likely to withdraw from the labour market after childbirth and to have several children during the same career break. These results are in line with Arntz et al. (2017).

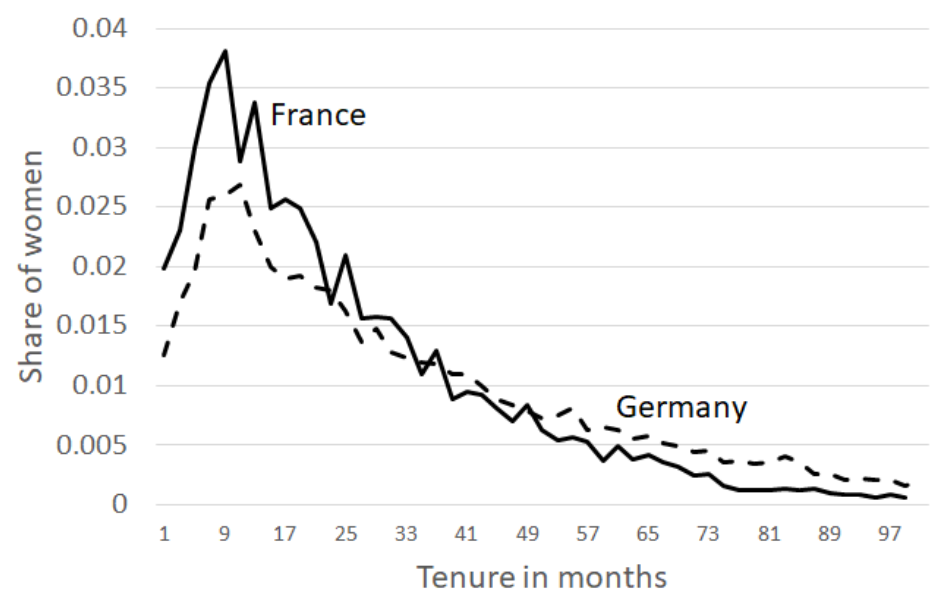

Figure 5: Tenure at birth

Notes: Share of women delivering a child by tenure.

Figure 5 shows the distribution of females giving birth to a child as a function of employ- 
ment duration at the same establishment (tenure). Since in both countries paid maternity leave starts six weeks before birth, we focus on tenure prior to maternity leave and thus show tenure two months before birth. In both countries, the propensity initially increases until up to ten months and thereafter begins to decrease. The peak at about twelve months prior to birth is higher in France than in Germany and the subsequent decrease is steeper in France than in Germany. This does not reflect the incentives set by the eligibility criteria for the child-rearing benefit in France, which require at least 24 months of employment with the same employer prior to birth. At tenure levels of more than three years, the share of women giving birth for the first time is higher in Germany than in France. This is likely due to the finding that German women tend to have children later, after their full integration into the labour market.

We find descriptive evidence for fertility patterns to differ sizeably across the two countries. The remainder of the paper focuses on isolating partial relationships between relevant factors and fertility while holding the other factors constant.

\section{Econometric Approach}

We use count data regression models to estimate the partial relationship between various observable factors and the number of children born. In particular, we apply different Poisson panel regression models. This section only states the main model equations and definitions. A more detailed presentation is given in Appendix A.III. There we also discuss the adequateness of different model restrictions in relation to our application to fertility data.

Let $y_{i t}$ denote the number of children for female $i=1, \ldots, N$ and period $t=1, \ldots, T_{i}$. $y_{i t}$ can only take on non-negative integer values $m=0,1,2 \ldots$ The non-negative expected number of children conditional on individual characteristics $\boldsymbol{x}_{i t}(1 \times K)$ and an unobserved time-invariant individual effect $a_{i} \geq 0$ is

$$
E\left[y_{i t} \mid \boldsymbol{x}_{i t}, a_{i}\right]=a_{i} \lambda_{i t}=a_{i} \exp \left(\boldsymbol{x}_{i t} \boldsymbol{\beta}\right),
$$

where $\boldsymbol{\beta}$ is a $(K \times 1)$ vector of unknown parameters. It is common for count models to 
assume a Poisson distribution

$$
y_{i t} \mid \boldsymbol{x}_{i t}, a_{i} \sim \mathcal{P}\left(a_{i} \lambda_{i t}\right),
$$

despite the restriction that the Poisson distribution is fully characterised by its first moment. An important advantage of Poisson (panel) estimators is that they are consistent as long as the conditional mean is correctly specified (Gourieroux et al., 1984). This holds even with misspecified higher moments, although at the expense of efficiency. Models with other count distributions may therefore be more efficiently estimated but have the disadvantage of being more complex and time intensive. Given the size of our data set we give a lower priority to efficiency.

In the above model, the marginal effect (ME) of the $j$ 'th (continuous) component of $\boldsymbol{x}_{i t}$, $x_{i t j}$, on the expected number of children is

$$
M E_{j}=\frac{\partial E\left[y_{i t} \mid \boldsymbol{x}_{i t}, a_{i}\right]}{\partial x_{i t j}}
$$

In a model without interaction terms we have

$$
M E_{j}=a_{i} \exp \left(\boldsymbol{x}_{i t} \boldsymbol{\beta}\right) \beta_{j}=\beta_{j} E\left[y_{i t} \mid \boldsymbol{x}_{i t}, a_{i}\right]
$$

which depends on $\boldsymbol{x}_{i t}$ and $a_{i}$. Computing the marginal effect is not possible without knowing $a_{i}$. However, $\beta_{j}$ gives the proportionate increase in $E\left[y_{i t} \mid \boldsymbol{x}_{i t}, a_{i}\right]$ when $x_{i t j}$ changes by one unit and can therefore be interpreted as semi-elasticity. The correlated random effects (CRE) model assumes the conditional expectation of $a_{i}$ to be linear in $\boldsymbol{x}_{i t}$. In contrast to the random effects (RE) model, however, it does not assume independence. An appealing advantage of the CRE model is that it computes coefficients for the time constant variables and permits computation of (average) marginal effects, since $E\left[a_{i} \mid \mathbf{x}_{i t}\right]$ is known. Estimation can be done by maximum likelihood (ML). Serial correlation between observations for the same female requires further corrections. We therefore report cluster-robust standard errors, which are implemented using block bootstrap, where clustering is done at the individual level. For comparison we also estimate a linear fixed effects model which is much simpler but does not restrict the count variable to be nonnegative and integer valued.

We estimate pooled, RE, CRE and fixed effects (FE) variants of the Poisson model that 
differ in the restrictions required for consistency, in particular for the relationship between $a_{i}$ and the $\boldsymbol{x}_{i t}$. A comprehensive technical treatment of these models is given in Appendix A.III along with a detailed discussion of how these models are affected in absence of strict exogeneity of regressors. We argue that the FE and CRE models are more adequate in the context of our application because they permit for correlation between observables and unobservables. In what follows, we mainly refer to the results for the CRE model, because it is only possible to compute the average ME for the CRE model. Most of the obtained patterns appear robust across models. We evaluate the average ME for unit changes in one of the variables by computing sample averages of differences in estimated conditional expectations, while holding all other variables constant at their observed values.

\section{Empirical Results}

For both countries, a Wald-test strongly rejects the hypothesis that unobserved correlated individual characteristics do not play a role at a significance level lower than 0.001 . Hence, we report and interpret the results for the Poisson CRE model for the two countries. The full set of results for the Poisson and linear regressions is given in the Appendix (Table A.3 and A.4). As outlined in Section 5 we focus our interpretation on the average ME; reported in Figure 6 along with their 95\% block bootstrap confidence intervals.

When we compare the results for the two countries, we make several interesting observations. Within each country, higher opportunity costs generally harm fertility outcomes. Impacts of current employment, wages and education are similar in direction for both countries, though more sizeable in Germany as predicted by our economic model. Using the population average counterfactual fertility we show that the relatively lower German birth rates are indeed due to opportunity costs related to observed, employment related characteristics and not due to unobservables. While the results regarding opportunity costs are in accordance with main findings of empirical micro and macro studies (Heckman and Walker, 1990; Winkelmann and Zimmermann, 1994; Wang and Famoye, 1997; Brewster and Rindfuss, 2000; Francesconi, 2002; Ahn and Mira, 2002; Billari and Kohler, 2004; Adsera, 2004; Baudin et al., 2015; Adda et al., 2017), we detect a positive income effect for high female wages in both countries, which is in contrast to findings of previous studies. We provide evidence for fertility decisions not being static as the timing of births depends on tenure, 


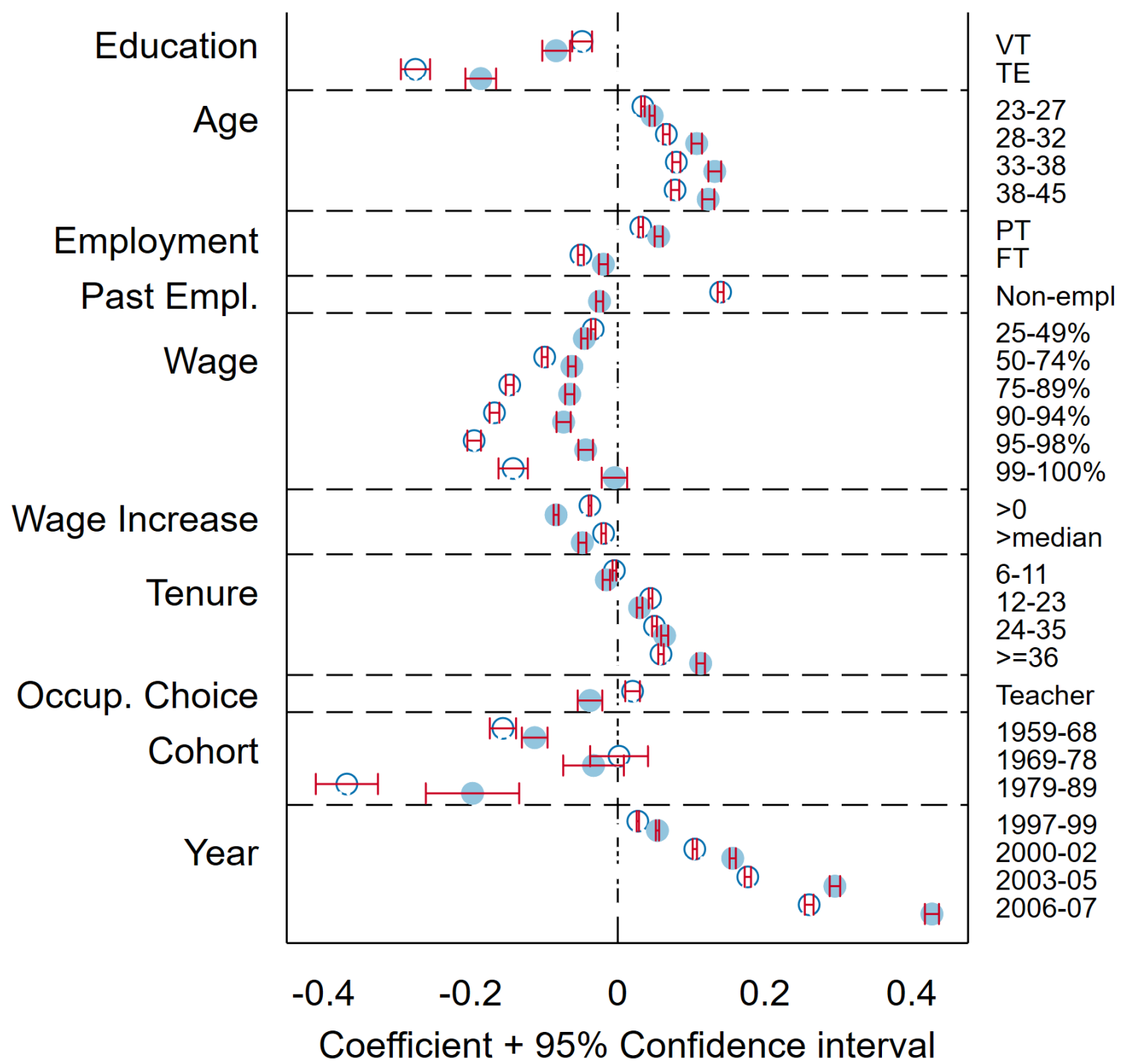

$\bigcirc$ Germany France

Figure 6: Average Marginal Effects of the Poisson CRE Model

Notes: The dependent variable is number of children. The graph is based on Tables A.3 and A.4 in the Appendix. For better visibility, marginal effects of age are divided by 10. Confidence intervals are based on 100 bootstrap replications (this value was chosen due to very long computing times). VT=Vocational Training, TE=Tertiary Education, $\mathrm{PT}=$ Part-time, FT=Full-time. 
age and state of employment in both countries. Trends in fertility behaviour are similar in both countries as the effects of cohort and year suggest. For both countries, the youngest cohorts have dramatically fewer children than earlier cohorts. Even though we control for age among other factors and hold them constant, the estimate for the youngest cohort could be affected because the youngest cohort is still young at the end of the observed period. For this reason it was not considered in the descriptive analysis.

In what follows, we focus on variables related to opportunity costs and income effect (Paragraph $A$ ), variables related to the timing of births (Paragraph $B$ ), and compare average birth rates with average counterfactual birth rates for both countries (Paragraph $C$ ).

A - Opportunity Costs and Income Effect For both countries, higher educational attainment is associated with a lower number of children. These partial relationships are significant and large in magnitude. For categorical variables, such as education and wage, it is of interest to consider both the estimated partial effect in relation to the reference level and the difference in estimated effects between levels. We observe differences in the pattern over educational levels between France and Germany: having a vocational training reduces the number of children by 0.08 children in France, while having a university degree further decreases the number of children by 0.11 children. The estimated partial effect is smaller in size for German trained professionals (-0.05), but the additional decrease for university graduates is much stronger $(-0.23)$. With more than 0.25 children compared to the reference level, having a tertiary education diploma sizeably affects fertility in Germany. This finding is in line with most other studies (Winkelmann and Zimmermann, 1994; Wang and Famoye, 1997; Jones and Tertilt, 2008; Baudin et al., 2015). However, for young US-American women, Hazan and Zoabi (2015) report higher fertility rates for highly educated women than for medium educated women. In addition to the level effect of education on the number of children, the interaction terms of age with education suggest that a higher educational level of the mother is associated with a stronger postponement of birth in both countries (see Table A.3 and A.4 in the Appendix). While in Germany the postponement is more pronounced the higher the educational level, in France females with completed vocational training do not postpone birth more strongly than females with no formal educational degree. Using similar categories of education, Lauer and Weber (2003) find no significant effect of education on the overall birth decision in Germany, except for postponement of 
birth. Although related, their results are not directly comparable because they consider a binary fertility decision.

We also provide evidence that higher wages are associated with a decrease in the number of children. Although this is found to be present in both countries, the effect is much stronger in magnitude for Germany than for France. This indicates that higher opportunity costs induced by a weaker work-family compatibility indeed play a role. Theses findings contrast those of Lauer and Weber (2003), who do not find evidence that wages are related to the birth decision. The effect of wages varies with the wage level, in particular, there is evidence for a positive income effect for high female wages. In Germany, the average ME for the top one percentile (around 10,000 observations) are significantly higher than those in the lower wage bracket. In France, this pattern already starts at the top five percentile. For French females in the top one percentile (around 6,000 observations), the wage effect is not even significantly negative. This positive relation at high wage brackets is robust to different specifications of the econometric model and to the inclusion of further control variables and is of high interest as it differs from most previous studies (e.g. Winkelmann and Zimmermann,1994; Wang and Famoye,1997; Jones and Tertilt, 2008). We see two possible explanations for the pattern for high wages: firstly, the wage pattern matches the pattern of the financial incentives set by aggregate tax reductions (see Section 2). These incentives also justify why the positive effect at high wages is stronger in France than in Germany. A second explanation can be linked to the findings by Hazan an Zoabi (2015) for the US. They claim that the use of childminders leads to changes in relative costs of childcare. The substitution of the childminders' time for parental time leads to a higher fertility for highly educated females. Since we do not observe potential partners, this substitution might also take place with respect to the spouse. It is interesting to note that in France and Germany the proposed substitution of someone else's time for own time takes place only with regard to wages and not with regard to education. Opportunity costs of having children consist of foregone wages, skill depreciation, career impediment, and lost utility intrinsic to paid work. If we assume that the effect of education is likely to capture skill depreciation and career impediment and that the estimated parameter of income captures opportunity costs in terms of foregone wages, our results suggest that the positive income effect at high wage levels can outbalance opportunity costs caused by foregone wages but cannot cancel out costs incurred by career damages and skill depreciation. 
Regarding the employment status, opportunity costs of having children also weigh more heavily for females in Germany than in France. The significant negative effect of full-time employment is estimated to be more than twice as large for Germany (-0.05) as for France (0.02). Our results suggest that working part-time increases the propensity of having children both compared to not being employed and to being full-time employed in both countries. Part-time employment seems to act as a typical instrument enabling women to combine family and work.

The significant positive German coefficient of being a primary or nursery school teacher suggests that the sorting of women who plan to have a (large) family into professions with a high amenity value regarding children indeed takes place. This confirms results found by Adda et al. (2017) for Germany. Interestingly, the same coefficient is negative for France, probably because the conciliation between children and work is better for many professions.

To sum up, opportunity costs reduce the number of children in both countries, with the extent being much larger in Germany than in France. A positive income effect is detected for high female wages, which in turn is more pronounced in France than in Germany.

B - Timing of births The descriptive findings presented in Section 4 suggest that the timing of births is related to age, tenure at the current firm, the past (in addition to the current) employment and the career stage. This is supported by our estimates of partial relationships. In particular, our results suggest for the two countries that the longer the tenure, the greater the marginal effect on fertility. While the effect is virtually zero for a period up to one year, it becomes increasingly sizeable for longer tenure. This pattern is more pronounced for France, presumably because it is more common for mothers in France to return to the same employer after childbirth than for mothers in Germany (Rodrigues and Vergnat, 2018 for France; Arntz et al., 2017 for Germany). Eligibility for French childrearing benefit requires two years of tenure before birth. While the average ME of two to three years tenure is larger than the ME for one to two years, it is smaller than the ME for three or more years of tenure. Thus, in line with the descriptive evidence and probably related to the low take-up rates, we do not find indication of substantial strategic adaptation of the timing of births to ensure benefit eligibility.

Following Francesconi (2002), an increase in female wage serves as proxy for career advancement and is thus associated with additional opportunity costs. In both countries, 
experiencing a wage increase significantly reduces the number of children. The estimated ME is rather small in size though, in particular in Germany.

Having been non-employed during the past year significantly and importantly increases fertility in Germany $(+0.14)$. It seems that the positive effect of reduced opportunity costs outweighs the negative effect of enhanced economic insecurity. The German data allows us to disentangle the effect of past unemployment from the effect of past inactivity. Table S.1 in the supplementary material S.II presents estimation results when variables indicating other labour market states are included. Interestingly, even past unemployment has a significantly positive effect on fertility. However, the positive effect of past inactivity is much larger in size: past inactivity increases the absolute number of children by 0.5 children. This finding supports the results by Arntz et al. (2017) who find a high propensity for German women to have a second child during the job protection period of the first child. The French coefficient of non-employment on fertility is negative and significantly different from zero. Mothers in France appear to behave differently. However, the composition of the effect of nonemployment cannot be assessed in France due to data restrictions. In France, opportunity costs of having children might be small to the point that a reduction in opportunity costs due to non-employment cannot compensate the negative effect of economic insecurity. The negative effect might also be related to the finding by Rodrigues and Vergnat (2018) that the proportion of mothers having a second child during the parental leave period of the first child is small.

In summary, females in both countries postpone birth to later ages and refrain from having children shortly after a wage promotion. The effects of tenure and past employment differ between both countries, likely due to differences in labour market participation around childbirth.

The supplementary material (S.II) contains additional results. The country-specific regressions with enlarged regressor set suggest that the patterns of Figure 6 are mainly robust, which indicates that the omission of certain variables is not harmful. In addition to the country-specific regressions, robustness checks have been conducted using different cut-off dates when constructing the yearly panel. No relevant differences have been detected.

C - Average Birth Rates and Counterfactual Analysis The existing literature using micro and macro data is somewhat contradictory regarding the relationship between female 
labour force attachment and wages on the one side and fertility on the other side. While studies based on micro data find evidence for a negative relationship (e.g. Heckman and Walker, 1990; Winkelmann and Zimmermann, 1994; Wang and Famoye, 1997; Francesconi, 2002; Jones and Tertilt, 2008; Baudin et al., 2015; Adda et al., 2017), macro data based results suggest the opposite (Brewster and Rindfuss, 2000; Ahn and Mira, 2002; Billari and Kohler, 2004; Adsera, 2004). We use the available data and regression results to compare population average fertility with counterfactual fertility. This is, we consider the hypothetical scenario that the population of females in one country behaved according to the parameters of the other country. The resulting numbers are shown in Table 4.

Table 4: Average number of children

\begin{tabular}{lccc}
\hline \hline & Sample average & Average predicted & Average counterfactual** \\
\hline $\mathrm{G}$ & 0.65 & 0.76 & 1.05 \\
$\mathrm{~F}$ & 1.04 & 1.13 & 0.28 \\
\hline \hline
\end{tabular}

* Sample average of fitted values from the CRE Poisson model (Table A.3 and A.4, column 6).

** Sample average of fitted values using the coefficients of the individual-specific effect from the CRE Poisson model from the own country and the coefficients on observables from the CRE Poisson model from the other country.

The average number of children is higher in France (1.04) than in Germany (0.65). The CRE Poisson model predicts slightly higher means for the two countries but it is not far off. The counterfactual average number of children for females in Germany if they had the coefficients from France is 1.05, while the same number is 0.28 for females in France if they had the coefficients from Germany. Our little exercise shows that the observed economic and demographic factors of our model are adequate to approximate average fertility and that the country differences in average fertility can be well explained by diverging responses to the observed factors. Conversely, country differences in unobserved factors, such as culture or norms, or different composition of observables across countries, are not the drivers behind the staggering gap in aggregate fertility between the two countries.

\section{Conclusions}

During the 1990's and 2000's a substantial decrease in birth rates was observed in Germany, while birth rates in France remained stable at a roughly $50 \%$ higher level. In this paper, we argue that the relatively low rate in Germany is mainly due to the fact that German 
women adapt their birth decisions much more to economic incentives than their French counterparts. The degree of adjustment to economic aspects depends on the opportunity costs of children caused by lost earnings opportunities and career damages. The effect of opportunity costs on the number of children is about twice as high in Germany as in France. We motivate this result by better childcare arrangements in France which facilitate the combination of motherhood and career. Interestingly, and in contrast to previous findings, we detect a positive income effect at high levels of earnings. In France, this pattern is more pronounced and corresponds to a large extent to the financial incentives set by the overall family policy mix. We provide evidence that adjustments take place not only with respect to the number of children, but also with respect to the timing of births. Especially in Germany, highly educated women have a strong tendency to postpone births to a later age when career advancements are supposed to have already taken place. Besides with age, the timing of births is aligned with the employment status. In addition to finding stronger negative effects of opportunity costs in Germany, we confirm by constructing counterfactuals that lower birth rates in Germany are due to different observable parameters of the female fertility decision.

We reason that differences in opportunity costs and unobserved individual preferences in relation to fertility arise from national policies, institutions and societal approaches. Our results suggest that the former drive the differences in fertility behaviour between both countries and within each country. Therefore, our results reconcile the ostensible contradiction between the positive relationship of fertility and female labour force participation across countries and the negative relationship within a country. 


\section{References}

[1] Adda, J., Dustmann, C., Stevens, K. (2017). The career costs of children. Journal of Political Economy, 125(2), 293-337.

[2] Adema W., Thévenon O. (2008). Les politiques de conciliation du travail et de la vie familiale en France au regard des pays de l'OCDE. Revue des politiques sociales et familiales, 93(1), 51-72.

[3] Adsera, A. (2004). Changing fertility rates in developed countries. The impact of labor market institutions. Journal of Population Economics, 17(1), 17-43.

[4] Ahn, N., Mira, P. (2002). A note on the changing relationship between fertility and female employment rates in developed countries. Journal of Population Economics, 15(4), 667-682.

[5] Algava, E., Bresse, S., Momic, M. (2005). Les bénéficiaires de l'Allocation parentale d'éducation: trajectoires d'activité et retour à l'emploi. Etudes et Resultats, 399. Paris: DREES.

[6] Arntz, M., Dlugosz, S., Wilke, R. A. (2017). The sorting of female careers after first birth: a competing risks analysis of maternity leave duration. Oxford Bulletin of Economics and Statistics, 79(5), 689-716.

[7] Baclet, A., Dell, F., Wrohlich, K. (2005). Income taxation and household size: would French family splitting make German families better off?. DIW Discussion Papers No. 542.

[8] Baudin, T., De la Croix, D., Gobbi, P. E. (2015). Fertility and childlessness in the United States. American Economic Review, 105(6), 1852-82.

[9] Bauernschuster, S., Hener, T., Rainer, H. (2016). Children of a (policy) revolution: The introduction of universal child care and its effect on fertility. Journal of the European Economic Association, 14(4), 975-1005.

[10] Bechtel J., Caussat L., Courtioux P., Laib N., Le Minez S., B. Mirouse (2005): La politique familiale française : coûts et bénéficiaires. In: Godet M., Sullerot E.: La Famille, 
une affaire publique, Council of Economic Analysis, 57: La documentation française, 409437.

[11] Billari, F., Kohler, H. P. (2004). Patterns of low and lowest-low fertility in Europe. Population Studies, 58(2), 161-176.

[12] Brewster, K. L., Rindfuss, R. R. (2000). Fertility and women's employment in industrialized nations. Annual Review of Sociology, 26(1), 271-296.

[13] Caudill, S. B., Mixon, F. G. (1995). Modeling household fertility decisions: Estimation and testing of censored regression models for count data. Empirical Economics, 20(2), 183-196.

[14] Del Boca, D. (2002). The effect of child care and part time opportunities on participation and fertility decisions in Italy. Journal of population economics, 15(3), 549-573.

[15] Del Boca, D., Sauer, R. M. (2009). Life cycle employment and fertility across institutional environments. European Economic Review, 53(3), 274-292.

[16] Fagnani, J. (2010). Childcare policies in France: the influence of organizational changes in the workplace. In: From Child Welfare to Child Well-Being, 385-402. Springer, Dordrecht.

[17] Fagnani, J., Math, A. (2010). Recent reforms in French and German family policies: Similar challenges, different responses. Sociologia, problemas e praticas, (64), 11-35.

[18] Francesconi, M. (2002). A joint dynamic model of fertility and work of married women. Journal of Labor Economics, 20(2), 336-380.

[19] Gauthier, A. H. (2007). The impact of family policies on fertility in industrialized countries: a review of the literature. Population Research and Policy Review, 26(3), 323346.

[20] Gourieroux, C., Monfort, A., Trognon, A. (1984). Pseudo maximum likelihood methods: Applications to Poisson models. Econometrica, 701-720.

[21] Hantrais, L. (2004). Family policy matters: Responding to family change in Europe. Policy Press. 
[22] Hazan, M., Zoabi, H. (2015). Do highly educated women choose smaller families?. The Economic Journal, 125(587), 1191-1226.

[23] Heckman, J. J., Walker, J. R. (1990). The relationship between wages and income and the timing and spacing of births: Evidence from Swedish longitudinal data. Econometrica, 1411-1441.

[24] Hochfellner, D., Müller, D. Wurdack, A. (2011). BASiD - Biografiedaten ausgewählter Sozialversicherungsträger in Deutschland. FDZ-Datenreport, 09/2011.

[25] Jones, L. E., Tertilt, M. (2008). An Economic History of Fertility in the United States: 1826-1960. In: P. Rupert (editor), Frontiers of family economics, Chapter 5, 165-230, Elsevier.

[26] Lauer, C., Weber, A. M. (2003). Employment of mothers after childbirth: A FrenchGerman comparison. ZEW Discussion Paper, 03-50.

[27] Lewis, J., Knijn, T., Martin, C., Ostner, I. (2008). Patterns of development in work/family reconciliation policies for parents in France, Germany, the Netherlands, and the UK in the 2000s. Social Politics, 15(3), 261-286.

[28] McDonald, P. (2006). Low fertility and the state: The efficacy of policy. Population and Development Review, 32(3), 485-510.

[29] Melkersson, M., Rooth, D. O. (2000). Modeling female fertility using inflated count data models. Journal of Population Economics, 13(2), 189-203.

[30] Morel, N. (2007). From subsidiarity to 'free choice': Child-and elder-care policy reforms in France, Belgium, Germany and the Netherlands. Social Policy $\&$ Administration, 41(6), 618-637.

[31] Piketty, T. (2005). Impact de l'Allocation Parentale d'Education sur l'Activite Feminine et la Fecondite en France. In: Histoires de Familles, Histoires Familiales, ed. C. Lefevre, 79-109. Les Cahiers de l'INED, 156.

[32] Plantenga, J., Remery, C., Helming, P., Meulders, D., Kanjuo-Mrčela, A. (2005). Reconciliation of work and private life: A comparative review of thirty European countries. Luxembourg, office for official publications of the European Communities. 
[33] Rodrigues, B., Vergnat, V. (2018). The time and the transitions back to work in France after maternity. Review of Economics of the Household, 17(3), 861-888.

[34] Salles, A., Rossier, C., Brachet, S. (2010). Understanding the long term effects of family policies on fertility: The diffusion of different family models in France and Germany. Demographic Research, 22, 1057-1096.

[35] Silva, J. S., Covas, F. (2000). A modified hurdle model for completed fertility. Journal of Population Economics, 13(2), 173-188.

[36] Sobotka, T., Beaujouan, E. (2014). Two Is best? The persistence of a two-child family ideal in Europe. Population and Development Review, 40(3), 391-419.

[37] Wang,W., Famoye, F. (1997). Modeling household fertility decisions with generalized Poisson regression. Journal of Population Economics, 10(3), 273-283.

[38] Winkelmann, R., Zimmermann, K. F. (1994). Count data models for demographic data. Mathematical Population Studies, 4(3), 205-221.

\section{Web Sources}

[39] OECD (2019a). Labour force participation rate (indicator). doi: 10.1787/8a801325-en. Accessed 14 May 2019.

[40] OECD (2019b). Hours worked (indicator). doi: 10.1787/47be1c78-en. Accessed 14 May 2019.

[41] OECD (2019c). Family benefits public spending (indicator). doi: 10.1787/8e8b3273-en. Accessed 26 Feb 2019.

[42] World Bank (2019a). Fertility rate, total (births per woman). World Development Indicators. The World Bank Group, 2019. databank.worldbank.org/data/reports.aspx?source=2\& series=SP.DYN.TFRT.IN\& country=. Accessed 14 May 2019.

[43] World Bank (2019b). Birth rate, crude (per 1,000 people). World Development Indicators. The World Bank Group, 2019. data.worldbank.org/indicator/SP.DYN.CBRT.IN. Accessed 14 May 2019. 


\section{A.I Tables}

Table A.1: Summary of child-rearing benefits in France and Germany

\begin{tabular}{|c|c|c|}
\hline & $\begin{array}{l}\text { APE - France } \\
1985-2004\end{array}$ & $\begin{array}{l}\text { Erziehungsgeld - Germany } \\
1986-2007\end{array}$ \\
\hline $\begin{array}{l}\text { Min. number } \\
\text { of children re- } \\
\text { quired for eligi- } \\
\text { bility }\end{array}$ & $\begin{array}{l}1985 \text { - 1994: three } \\
1994 \text { - 2004: two } \\
\text { since } 2004 \text { (CLCA): one }\end{array}$ & One \\
\hline Benefit duration & $\begin{array}{l}3 \text { years (CLCA with only one } \\
\text { child: } 6 \text { months) }\end{array}$ & $\begin{array}{l}8 \text { months gradually increased to } \\
22 \text { months }\end{array}$ \\
\hline $\begin{array}{l}\text { Past employ- } \\
\text { ment condition }\end{array}$ & $\begin{array}{l}\text { for parents with three or more } \\
\text { children: } 2 \text { of the } 10 \text { years preced- } \\
\text { ing birth; for parents with only } \\
\text { two children: } 2 \text { of the } 5 \text { years }\end{array}$ & None \\
\hline $\begin{array}{l}\text { Income condi- } \\
\text { tion }\end{array}$ & None & $\begin{array}{l}\text { From month } 7 \text { : Annual net family } \\
\text { income }<29.400 \mathrm{DM}+4.200 \mathrm{DM} \\
\text { for each addit. child. } \\
\text { Since 2001: During first six } \\
\text { months } 30.000 € \text {. From month } \\
7 \text { : benefit reduction if income } \\
>16.500 € \text {. Each time }+3.140 € \\
\text { for each addit. } \text { child }^{1}\end{array}$ \\
\hline $\begin{array}{l}\text { Partial employ- } \\
\text { ment }\end{array}$ & Yes, but benefit reduction & $\begin{array}{l}\text { Up to } 15 \mathrm{~h} / \text { week without benefit } \\
\text { reduction (since 1989: } 19 \mathrm{~h} / \text { week, } \\
\text { since 2001: } 30 \mathrm{~h} / \text { week) }\end{array}$ \\
\hline Amount (1994) & $450 € /$ month & $300 € /$ month \\
\hline Take-up rate ${ }^{2}$ & $<50 \%$ & $85 \%$ \\
\hline
\end{tabular}

Source: If not stated otherwise, Fagnani, 1994. ${ }^{1}$ Bundesministerium für Familie, Senioren, Frauen und Jugend, 2004. ${ }^{2}$ Plantenga et al., 2005. 
Table A.2: Description of the independent variables

\begin{tabular}{|c|c|c|c|c|}
\hline Factor & $\begin{array}{l}\text { Time } \\
\text { variant }\end{array}$ & Description & $\begin{array}{c}\mathrm{S} \\
\text { Germany }\end{array}$ & $\begin{array}{l}\text { hare in \% } \\
\text { France }\end{array}$ \\
\hline \multirow[t]{5}{*}{ Age } & \multirow[t]{5}{*}{ Yes } & 18-22 years & 17.8 & 16.1 \\
\hline & & $23-27$ years & 21.1 & 19.7 \\
\hline & & 28-32 years & 21.2 & 20.3 \\
\hline & & $33-37$ years & 18.3 & 19.7 \\
\hline & & $38-45$ years & 21.7 & 24.3 \\
\hline \multirow[t]{3}{*}{ Education } & \multirow[t]{3}{*}{ No } & No VT & 20.2 & 13.4 \\
\hline & & VT & 45.9 & 55.2 \\
\hline & & $\mathrm{TE}$ & 32.9 & 31.4 \\
\hline \multirow[t]{3}{*}{ Employment } & \multirow[t]{3}{*}{ Yes } & $\underline{\text { Not employed }}$ & 42.4 & 53.5 \\
\hline & & Part-time & 18.0 & 15.9 \\
\hline & & Full-time & 37.9 & 30.6 \\
\hline Past employment & Yes & Not employed & 50.4 & 64.2 \\
\hline \multirow[t]{7}{*}{ Gross Wage } & \multirow[t]{7}{*}{ Yes } & $\leq 25 \%$ & 56.8 & 64.1 \\
\hline & & $<50 \%$ & 14.4 & 11.4 \\
\hline & & $<75 \%$ & 14.4 & 12.0 \\
\hline & & $<90 \%$ & 8.6 & 7.5 \\
\hline & & $<95 \%$ & 2.9 & 2.5 \\
\hline & & $<99 \%$ & 2.3 & 2.0 \\
\hline & & $>=99 \%$ & 0.6 & 0.5 \\
\hline \multirow{3}{*}{$\begin{array}{l}\text { Change in wage relative } \\
\text { to past year }\end{array}$} & \multirow[t]{3}{*}{ Yes } & negative & 21.2 & 18.3 \\
\hline & & positive & 45.9 & 30.4 \\
\hline & & $>$ median & 32.9 & 51.3 \\
\hline \multirow[t]{5}{*}{ Tenure at firm } & \multirow[t]{5}{*}{ Yes } & $\leq 6$ months & 10.2 & 12.1 \\
\hline & & 6-11 months & 7.9 & 4.0 \\
\hline & & 12-23 months & 12.8 & 10.6 \\
\hline & & 24-36 months & 9.5 & 8.4 \\
\hline & & $>36$ months & 59.5 & 65.0 \\
\hline Child-friendly profession & Yes & Yes & 2.2 & 2.2 \\
\hline Twins & Yes & Yes & 0.7 & 0.6 \\
\hline Multiples & Yes & Yes & 0.0 & 0.5 \\
\hline \multirow[t]{3}{*}{ Birth cohort } & \multirow[t]{3}{*}{ No } & $\underline{1949-58}$ & 8.3 & 9.1 \\
\hline & & $1959-68$ & 32.4 & 36.9 \\
\hline & & 1969-78 & 44.2 & 39.5 \\
\hline
\end{tabular}




\begin{tabular}{|c|c|c|c|c|}
\hline Factor & $\begin{array}{l}\text { Time } \\
\text { variant }\end{array}$ & Description & $\begin{array}{c}\mathrm{S} \\
\text { Germany }\end{array}$ & $\begin{array}{l}\text { hare in \% } \\
\text { France }\end{array}$ \\
\hline & & 1979-89 & 15.1 & 14.5 \\
\hline \multirow[t]{5}{*}{ Year } & Yes & $\underline{1994-1996}$ & 19.9 & 20.0 \\
\hline & & 1997-1999 & 21.2 & 21.7 \\
\hline & & $2000-2002$ & 22.1 & 22.6 \\
\hline & & $2003-2005$ & 22.3 & 22.1 \\
\hline & & $2006-2007$ & 14.5 & 13.6 \\
\hline \multicolumn{5}{|c|}{ Variables only observed for France } \\
\hline Île-de-France & Yes & Yes & & 21.1 \\
\hline Married & Yes & Yes & & 31.8 \\
\hline Born overseas & No & Yes & & 2.0 \\
\hline \multicolumn{5}{|c|}{ Variables only observed for Germany } \\
\hline Former GDR & No & Yes & 13.6 & \\
\hline \multirow[t]{11}{*}{ Federal state } & Yes & No info. & 24.4 & \\
\hline & & SH \& MV & 3.1 & \\
\hline & & LS \& B & 6.3 & \\
\hline & & NRW & 16.7 & \\
\hline & & Hesse & 6.6 & \\
\hline & & $\mathrm{RP} \& \mathrm{~S}$ & 4.4 & \\
\hline & & BW & 11.4 & \\
\hline & & Bavaria & 12.5 & \\
\hline & & B \& H & 5.1 & \\
\hline & & S \& B & 5.7 & \\
\hline & & $\mathrm{T} \& \mathrm{SA}$ & 3.9 & \\
\hline Foreigner $^{1}$ & No & Yes & 34.7 & \\
\hline Unempl. last year & Yes & Yes & 16.1 & \\
\hline Inactive last year & Yes & Yes & 14.2 & \\
\hline Unobs. last year & Yes & Yes & 23.7 & \\
\hline
\end{tabular}

Notes: ${ }^{1}$ Based on nationality. Reference categories of the following regressions are underscored. SH \& MV $=$ Schleswig-Holstein \& Mecklenburg-Western Pomerania, LS \& B = Lower Saxony \& Bremen, NRW $=$ North Rhine-Westphalia, RP \& $\mathrm{S}=$ Rhineland-Palatinate \& Saarland, BW $=$ Baden-Wuerttemberg, B \& H = Berlin \& Hamburg, S \& B = Saxony \& Brandenburg, $\mathrm{T} \& \mathrm{SA}=$ Thuringia \& Saxony-Anhalt. 
Table A.3: Baseline Results Germany

\begin{tabular}{|c|c|c|c|c|c|c|c|}
\hline & \multicolumn{2}{|c|}{ Linear } & \multicolumn{5}{|c|}{ Poisson } \\
\hline & OLS & $\mathrm{FE}$ & Pooled & $\mathrm{FE}$ & $\mathrm{RE}$ & $\mathrm{CRE}$ & CRE-ME \\
\hline \multicolumn{8}{|l|}{ Age } \\
\hline $23-27$ & $\begin{array}{l}0.23^{* * *} \\
(0.00)\end{array}$ & $\begin{array}{l}0.08^{* * *} \\
(0.00)\end{array}$ & $\begin{array}{l}1.26^{* * *} \\
(0.02)\end{array}$ & $\begin{array}{l}0.92^{* * *} \\
(0.02)\end{array}$ & $\begin{array}{l}1.00^{* * *} \\
(0.02)\end{array}$ & $\begin{array}{l}0.94^{* * *} \\
(0.02)\end{array}$ & $\begin{array}{l}0.34^{* * *} \\
(0.00)\end{array}$ \\
\hline $28-32$ & $\begin{array}{l}0.56^{* * *} \\
(0.01)\end{array}$ & $\begin{array}{l}0.23^{* * *} \\
(0.01)\end{array}$ & $\begin{array}{l}1.78^{* * *} \\
(0.02)\end{array}$ & $\begin{array}{l}1.23^{* * *} \\
(0.02)\end{array}$ & $\begin{array}{l}1.34^{* * *} \\
(0.02)\end{array}$ & $\begin{array}{l}1.25^{* * *} \\
(0.02)\end{array}$ & $\begin{array}{l}0.66^{* * *} \\
(0.01)\end{array}$ \\
\hline $33-37$ & $\begin{array}{l}0.83^{* * *} \\
(0.01)\end{array}$ & $\begin{array}{l}0.30^{* * *} \\
(0.01)\end{array}$ & $\begin{array}{l}2.08^{* * *} \\
(0.01)\end{array}$ & $\begin{array}{l}1.30^{* * *} \\
(0.02)\end{array}$ & $\begin{array}{l}1.43^{* * *} \\
(0.02)\end{array}$ & $\begin{array}{l}1.31^{* * *} \\
(0.02)\end{array}$ & $\begin{array}{l}0.80^{* * *} \\
(0.01)\end{array}$ \\
\hline $38-45$ & $\begin{array}{l}1.03^{* * *} \\
(0.02)\end{array}$ & $\begin{array}{l}0.27^{* * *} \\
(0.01)\end{array}$ & $\begin{array}{l}2.26^{* * *} \\
(0.02)\end{array}$ & $\begin{array}{l}1.23^{* * *} \\
(0.02)\end{array}$ & $\begin{array}{l}1.39^{* * *} \\
(0.02)\end{array}$ & $\begin{array}{l}1.24^{* * *} \\
(0.02)\end{array}$ & $\begin{array}{l}0.78^{* * *} \\
(0.01)\end{array}$ \\
\hline \multicolumn{8}{|l|}{ Education } \\
\hline $\mathrm{VT}$ & $\begin{array}{l}-0.01^{* * *} \\
(0.00)\end{array}$ & & $\begin{array}{l}-0.69^{* * *} \\
(0.02)\end{array}$ & & $\begin{array}{l}-0.59^{* * *} \\
(0.03)\end{array}$ & $\begin{array}{l}-0.58^{* * *} \\
(0.03)\end{array}$ & $\begin{array}{l}-0.05^{* * *} \\
(0.01)\end{array}$ \\
\hline $\mathrm{TE}$ & $\begin{array}{l}-0.11^{* * *} \\
(0.00)\end{array}$ & & $\begin{array}{l}-2.76^{* * *} \\
(0.08)\end{array}$ & & $\begin{array}{l}-2.48^{* * *} \\
(0.12)\end{array}$ & $\begin{array}{l}-2.34^{* * *} \\
(0.12)\end{array}$ & $\begin{array}{l}-0.28^{* * *} \\
(0.01)\end{array}$ \\
\hline \multicolumn{8}{|c|}{ Education $\times$ Age } \\
\hline $\mathrm{VT} \times 23-27$ & $\begin{array}{l}0.00 \\
(0.00)\end{array}$ & $\begin{array}{l}-0.01^{* * *} \\
(0.00)\end{array}$ & $\begin{array}{l}0.44^{* * *} \\
(0.02)\end{array}$ & $\begin{array}{l}0.33^{* * *} \\
(0.02)\end{array}$ & $\begin{array}{l}0.33^{* * *} \\
(0.02)\end{array}$ & $\begin{array}{l}0.33^{* * *} \\
(0.02)\end{array}$ & \\
\hline $\mathrm{TE} \times 23-27$ & $\begin{array}{l}-0.13^{* * *} \\
(0.00)\end{array}$ & $\begin{array}{l}-0.12^{* * *} \\
(0.00)\end{array}$ & $\begin{array}{l}0.96^{* * *} \\
(0.08)\end{array}$ & $\begin{array}{l}0.81^{* * *} \\
(0.10)\end{array}$ & $\begin{array}{l}0.86^{* * *} \\
(0.11)\end{array}$ & $\begin{array}{l}0.86^{* * *} \\
(0.11)\end{array}$ & \\
\hline $\mathrm{VT} \times 28-32$ & $\begin{array}{l}0.00 \\
(0.01)\end{array}$ & $\begin{array}{l}0.00 \\
(0.01)\end{array}$ & $\begin{array}{l}0.66^{* * *} \\
(0.02)\end{array}$ & $\begin{array}{l}0.49^{* * *} \\
(0.02)\end{array}$ & $\begin{array}{l}0.50^{* * *} \\
(0.03)\end{array}$ & $\begin{array}{l}0.50^{* * *} \\
(0.03)\end{array}$ & \\
\hline $\mathrm{TE} \times 28-32$ & $\begin{array}{l}-0.18^{* * *} \\
(0.01)\end{array}$ & $\begin{array}{l}-0.16^{* * *} \\
(0.01)\end{array}$ & $\begin{array}{l}1.98^{* * *} \\
(0.08)\end{array}$ & $\begin{array}{l}1.53^{* * *} \\
(0.11)\end{array}$ & $\begin{array}{l}1.66^{* * *} \\
(0.12)\end{array}$ & $\begin{array}{l}1.66^{* * *} \\
(0.12)\end{array}$ & \\
\hline $\mathrm{VT} \times 33-37$ & $\begin{array}{l}0.03^{*} \\
(0.01)\end{array}$ & $\begin{array}{l}0.03^{* * *} \\
(0.01)\end{array}$ & $\begin{array}{l}0.71^{* * * *} \\
(0.02)\end{array}$ & $\begin{array}{l}0.53^{* * *} \\
(0.03)\end{array}$ & $\begin{array}{l}0.55^{* * *} \\
(0.03)\end{array}$ & $\begin{array}{l}0.55^{* * *} \\
(0.03)\end{array}$ & \\
\hline $\mathrm{TE} \times 33-37$ & $\begin{array}{l}-0.14^{* * *} \\
(0.01)\end{array}$ & $\begin{array}{l}-0.09^{* * *} \\
(0.01)\end{array}$ & $\begin{array}{l}2.47^{* * *} \\
(0.08)\end{array}$ & $\begin{array}{l}1.83^{* * *} \\
(0.11)\end{array}$ & $\begin{array}{l}1.99^{* * *} \\
(0.12)\end{array}$ & $\begin{array}{l}1.99^{* * *} \\
(0.12)\end{array}$ & \\
\hline $\mathrm{VT} \times 38-45$ & $\begin{array}{l}0.01 \\
(0.01)\end{array}$ & $\begin{array}{l}0.02^{* *} \\
(0.01)\end{array}$ & $\begin{array}{l}0.71^{* * *} \\
(0.02)\end{array}$ & $\begin{array}{l}0.53^{* * *} \\
(0.03)\end{array}$ & $\begin{array}{l}0.55^{* * *} \\
(0.03)\end{array}$ & $\begin{array}{l}0.55^{* * *} \\
(0.03)\end{array}$ & \\
\hline $\mathrm{TE} \times 38-45$ & $\begin{array}{l}-0.07^{* * *} \\
(0.02)\end{array}$ & $\begin{array}{l}-0.05^{* * *} \\
(0.01)\end{array}$ & $\begin{array}{l}2.67^{* * *} \\
(0.08)\end{array}$ & $\begin{array}{l}1.88^{* * *} \\
(0.11)\end{array}$ & $\begin{array}{l}2.08^{* * *} \\
(0.12)\end{array}$ & $\begin{array}{l}2.07^{* * *} \\
(0.12)\end{array}$ & \\
\hline Employment & & & & & & & \\
\hline Part-time & $\begin{array}{l}0.26^{* * *} \\
(0.00)\end{array}$ & $\begin{array}{l}0.01^{* * *} \\
(0.00)\end{array}$ & $\begin{array}{l}0.39^{* * *} \\
(0.00)\end{array}$ & $\begin{array}{l}0.01^{* * *} \\
(0.00)\end{array}$ & $\begin{array}{l}0.03^{* * *} \\
(0.00)\end{array}$ & $\begin{array}{l}0.03^{* * *} \\
(0.00)\end{array}$ & $\begin{array}{l}0.03^{* * *} \\
(0.00)\end{array}$ \\
\hline Full-time & $\begin{array}{l}0.05^{* * *} \\
(0.00)\end{array}$ & $\begin{array}{l}-0.05^{* * *} \\
(0.00)\end{array}$ & $\begin{array}{l}0.10^{* * *} \\
(0.00)\end{array}$ & $\begin{array}{l}-0.09^{* * *} \\
(0.00)\end{array}$ & $\begin{array}{l}-0.09^{* * *} \\
(0.00)\end{array}$ & $\begin{array}{l}-0.09^{* * *} \\
(0.00)\end{array}$ & $\begin{array}{l}-0.05^{* * *} \\
(0.00)\end{array}$ \\
\hline Past Employ & nent & & & & & & \\
\hline
\end{tabular}

Continued on next page 


\begin{tabular}{|c|c|c|c|c|c|c|c|}
\hline & \multicolumn{2}{|c|}{ Linear } & \multicolumn{5}{|c|}{ Poisson } \\
\hline & OLS & $\mathrm{FE}$ & Pooled & $\mathrm{FE}$ & $\mathrm{RE}$ & $\mathrm{CRE}$ & CRE-ME \\
\hline Not empl. & $\begin{array}{l}0.28^{* * *} \\
(0.00)\end{array}$ & $\begin{array}{l}0.02^{* * *} \\
(0.00)\end{array}$ & $\begin{array}{l}0.42^{\text {*** }} \\
(0.00)\end{array}$ & $\begin{array}{l}0.11^{* * *} \\
(0.00)\end{array}$ & $\begin{array}{l}0.13^{* * *} \\
(0.00)\end{array}$ & $\begin{array}{l}0.11^{* * *} \\
(0.00)\end{array}$ & $\begin{array}{l}0.14^{* * *} \\
(0.00)\end{array}$ \\
\hline \multicolumn{8}{|l|}{ Wage } \\
\hline $25-49 \%$ & $\begin{array}{l}-0.05^{* * *} \\
(0.00)\end{array}$ & $\begin{array}{l}-0.05^{* * *} \\
(0.00)\end{array}$ & $\begin{array}{l}-0.09 * * * \\
(0.00)\end{array}$ & $\begin{array}{l}-0.03^{* * *} \\
(0.00)\end{array}$ & $\begin{array}{l}-0.04^{* * *} \\
(0.00)\end{array}$ & $\begin{array}{l}-0.04^{* * *} \\
(0.00)\end{array}$ & $\begin{array}{l}-0.03^{* * *} \\
(0.00)\end{array}$ \\
\hline $50-74 \%$ & $\begin{array}{l}-0.19^{* * *} \\
(0.00)\end{array}$ & $\begin{array}{l}-0.10^{* * *} \\
(0.00)\end{array}$ & $\begin{array}{l}-0.27^{* * *} \\
(0.00)\end{array}$ & $\begin{array}{l}-0.12^{\text {*** }} \\
(0.00)\end{array}$ & $\begin{array}{l}-0.14^{* * *} \\
(0.00)\end{array}$ & $\begin{array}{l}-0.12^{* * *} \\
(0.00)\end{array}$ & $\begin{array}{l}-0.10^{* * *} \\
(0.00)\end{array}$ \\
\hline $75-89 \%$ & $\begin{array}{l}-0.30^{* * *} \\
(0.01)\end{array}$ & $\begin{array}{l}-0.16^{* * *} \\
(0.00)\end{array}$ & $\begin{array}{l}-0.44^{* * *} \\
(0.00)\end{array}$ & $\begin{array}{l}-0.18^{* * *} \\
(0.00)\end{array}$ & $\begin{array}{l}-0.22^{* * *} \\
(0.00)\end{array}$ & $\begin{array}{l}-0.19^{* * *} \\
(0.00)\end{array}$ & $\begin{array}{l}-0.15^{* * *} \\
(0.00)\end{array}$ \\
\hline $90-94 \%$ & $\begin{array}{l}-0.39^{* * *} \\
(0.01)\end{array}$ & $\begin{array}{l}-0.19^{* * *} \\
(0.00)\end{array}$ & $\begin{array}{l}-0.58^{* * *} \\
(0.01)\end{array}$ & $\begin{array}{l}-0.20^{* *} \\
(0.00)\end{array}$ & $\begin{array}{l}-0.26^{* * *} \\
(0.01)\end{array}$ & $\begin{array}{l}-0.21^{* * *} \\
(0.01)\end{array}$ & $\begin{array}{l}-0.17^{* * *} \\
(0.00)\end{array}$ \\
\hline $95-98 \%$ & $\begin{array}{l}-0.49^{* * *} \\
(0.01)\end{array}$ & $\begin{array}{l}-0.20^{* * *} \\
(0.00)\end{array}$ & $\begin{array}{l}-0.85^{* * *} \\
(0.01)\end{array}$ & $\begin{array}{l}-0.22^{* * *} \\
(0.01)\end{array}$ & $\begin{array}{l}-0.31^{* * *} \\
(0.01)\end{array}$ & $\begin{array}{l}-0.25^{* * *} \\
(0.01)\end{array}$ & $\begin{array}{l}-0.20^{* * *} \\
(0.00)\end{array}$ \\
\hline $99-100 \%$ & $\begin{array}{l}-0.54^{* * *} \\
(0.01)\end{array}$ & $\begin{array}{l}-0.22^{* * *} \\
(0.01)\end{array}$ & $\begin{array}{l}-1.15^{* * *} \\
(0.02)\end{array}$ & $\begin{array}{l}-0.05^{* *} \\
(0.02)\end{array}$ & $\begin{array}{l}-0.22^{* * *} \\
(0.02)\end{array}$ & $\begin{array}{l}-0.15^{* * *} \\
(0.02)\end{array}$ & $\begin{array}{l}-0.14^{* * *} \\
(0.01)\end{array}$ \\
\hline \multicolumn{8}{|c|}{ Wage Increase } \\
\hline$>0$ & $\begin{array}{l}0.03^{* * *} \\
(0.00)\end{array}$ & $\begin{array}{l}0.01^{* * *} \\
(0.00)\end{array}$ & $\begin{array}{l}0.02^{* * *} \\
(0.00)\end{array}$ & $\begin{array}{l}-0.02^{* * *} \\
(0.00)\end{array}$ & $\begin{array}{l}-0.01^{* * *} \\
(0.00)\end{array}$ & $\begin{array}{l}-0.01^{* * *} \\
(0.00)\end{array}$ & $\begin{array}{l}-0.04^{* * *} \\
(0.00)\end{array}$ \\
\hline$>$ median & $\begin{array}{l}-0.11^{* * *} \\
(0.00)\end{array}$ & $\begin{array}{l}0.05^{* * *} \\
(0.00)\end{array}$ & $\begin{array}{l}-0.13^{* * *} \\
(0.00)\end{array}$ & $\begin{array}{l}0.06^{* * *} \\
(0.00)\end{array}$ & $\begin{array}{l}0.05^{* * *} \\
(0.00)\end{array}$ & $\begin{array}{l}0.06^{* * *} \\
(0.00)\end{array}$ & $\begin{array}{l}-0.02^{* * *} \\
(0.00)\end{array}$ \\
\hline \multicolumn{8}{|c|}{ Tenure in months } \\
\hline $6-11$ & $\begin{array}{l}0.02^{* * *} \\
(0.00)\end{array}$ & $\begin{array}{l}0.00 \\
(0.00)\end{array}$ & $\begin{array}{l}0.00 \\
(0.00)\end{array}$ & $\begin{array}{l}-0.01^{* * *} \\
(0.00)\end{array}$ & $\begin{array}{l}-0.01^{* * *} \\
(0.00)\end{array}$ & $\begin{array}{l}-0.01^{* * *} \\
(0.00)\end{array}$ & $\begin{array}{l}-0.00^{* * *} \\
(0.00)\end{array}$ \\
\hline $12-23$ & $\begin{array}{l}0.12^{* * *} \\
(0.00)\end{array}$ & $\begin{array}{l}0.02^{* * *} \\
(0.00)\end{array}$ & $\begin{array}{l}0.19^{* * *} \\
(0.00)\end{array}$ & $\begin{array}{l}0.04^{* * * *} \\
(0.00)\end{array}$ & $\begin{array}{l}0.05^{* * *} \\
(0.00)\end{array}$ & $\begin{array}{l}0.05^{* * *} \\
(0.00)\end{array}$ & $\begin{array}{l}0.04^{* * *} \\
(0.00)\end{array}$ \\
\hline $24-35$ & $\begin{array}{l}0.11^{* * *} \\
(0.00)\end{array}$ & $\begin{array}{l}0.01^{* * *} \\
(0.00)\end{array}$ & $\begin{array}{l}0.20^{* * *} \\
(0.00)\end{array}$ & $\begin{array}{l}0.04^{* * *} \\
(0.00)\end{array}$ & $\begin{array}{l}0.05^{* * *} \\
(0.00)\end{array}$ & $\begin{array}{l}0.05^{* * *} \\
(0.00)\end{array}$ & $\begin{array}{l}0.05^{* * *} \\
(0.00)\end{array}$ \\
\hline$\geq 36$ & $\begin{array}{l}0.09^{* * *} \\
(0.00)\end{array}$ & $\begin{array}{l}-0.00^{* * *} \\
(0.00)\end{array}$ & $\begin{array}{l}0.19^{* * *} \\
(0.00)\end{array}$ & $\begin{array}{l}0.04^{* * *} \\
(0.00)\end{array}$ & $\begin{array}{l}0.05^{* * *} \\
(0.00)\end{array}$ & $\begin{array}{l}0.05^{* * *} \\
(0.00)\end{array}$ & $\begin{array}{l}0.06^{* * *} \\
(0.00)\end{array}$ \\
\hline \multicolumn{8}{|c|}{ Occupational Choice } \\
\hline Teacher & $\begin{array}{l}0.08^{* * *} \\
(0.01)\end{array}$ & $\begin{array}{l}-0.01^{* *} \\
(0.00)\end{array}$ & $\begin{array}{l}0.15^{* * *} \\
(0.01)\end{array}$ & $\begin{array}{l}0.00 \\
(0.01)\end{array}$ & $\begin{array}{l}0.01^{*} \\
(0.01)\end{array}$ & $\begin{array}{l}0.03^{* * *} \\
(0.01)\end{array}$ & $\begin{array}{l}0.02^{* * *} \\
(0.01)\end{array}$ \\
\hline Cohort & & & & & & & \\
\hline $1959-68$ & $\begin{array}{l}-0.17^{* * *} \\
(0.01)\end{array}$ & & $\begin{array}{l}-0.10^{* * *} \\
(0.00)\end{array}$ & & $\begin{array}{l}-0.44^{* * *} \\
(0.01)\end{array}$ & $\begin{array}{l}-0.21^{* * *} \\
(0.01)\end{array}$ & $\begin{array}{l}-0.16^{* * *} \\
(0.01)\end{array}$ \\
\hline 1969-78 & $\begin{array}{l}-0.37^{* * *} \\
(0.01)\end{array}$ & & $\begin{array}{l}-0.34^{* * *} \\
(0.01)\end{array}$ & & $\begin{array}{l}-1.19^{* * *} \\
(0.01)\end{array}$ & $\begin{array}{l}0.01 \\
(0.02)\end{array}$ & $\begin{array}{l}0.00 \\
(0.02)\end{array}$ \\
\hline 1979-89 & $\begin{array}{l}-0.41^{* * *} \\
(0.02)\end{array}$ & & $\begin{array}{l}-1.25^{* * *} \\
(0.01)\end{array}$ & & $\begin{array}{l}-2.52^{* * *} \\
(0.02)\end{array}$ & $\begin{array}{l}-0.59^{* * *} \\
(0.04)\end{array}$ & $\begin{array}{l}-0.37^{* * *} \\
(0.02)\end{array}$ \\
\hline
\end{tabular}

Continued on next page 


\begin{tabular}{|c|c|c|c|c|c|c|c|}
\hline & \multicolumn{2}{|c|}{ Linear } & \multicolumn{5}{|c|}{ Poisson } \\
\hline & OLS & $\mathrm{FE}$ & Pooled & $\mathrm{FE}$ & $\mathrm{RE}$ & $\mathrm{CRE}$ & CRE-ME \\
\hline \multicolumn{8}{|l|}{ Year } \\
\hline $1997-1999$ & $\begin{array}{l}-0.03^{* * *} \\
(0.00)\end{array}$ & $\begin{array}{l}0.07^{* * *} \\
(0.00)\end{array}$ & $\begin{array}{l}-0.07^{* * *} \\
(0.00)\end{array}$ & $\begin{array}{l}0.05^{* * *} \\
(0.00)\end{array}$ & $\begin{array}{l}0.03^{* * *} \\
(0.00)\end{array}$ & $\begin{array}{l}0.04^{* * *} \\
(0.00)\end{array}$ & $\begin{array}{l}0.03^{* * *} \\
(0.00)\end{array}$ \\
\hline $2000-2002$ & $\begin{array}{l}-0.05^{* * *} \\
(0.00)\end{array}$ & $\begin{array}{l}0.15^{* * *} \\
(0.00)\end{array}$ & $\begin{array}{l}-0.12^{* * *} \\
(0.00)\end{array}$ & $\begin{array}{l}0.16^{* * *} \\
(0.00)\end{array}$ & $\begin{array}{l}0.13^{* * *} \\
(0.00)\end{array}$ & $\begin{array}{l}0.15^{* * *} \\
(0.00)\end{array}$ & $\begin{array}{l}0.10^{* * *} \\
(0.00)\end{array}$ \\
\hline $2003-2005$ & $\begin{array}{l}-0.09^{* * *} \\
(0.00)\end{array}$ & $\begin{array}{l}0.20^{* * *} \\
(0.00)\end{array}$ & $\begin{array}{l}-0.17^{* * *} \\
(0.00)\end{array}$ & $\begin{array}{l}0.25^{* * *} \\
(0.00)\end{array}$ & $\begin{array}{l}0.21^{* * *} \\
(0.00)\end{array}$ & $\begin{array}{l}0.24^{* * *} \\
(0.00)\end{array}$ & $\begin{array}{l}0.18^{* * *} \\
(0.00)\end{array}$ \\
\hline $2006-2007$ & $\begin{array}{l}-0.14^{* * *} \\
(0.01)\end{array}$ & $\begin{array}{l}0.25^{* * *} \\
(0.00)\end{array}$ & $\begin{array}{l}-0.22^{* * *} \\
(0.00)\end{array}$ & $\begin{array}{l}0.35^{* * *} \\
(0.00)\end{array}$ & $\begin{array}{l}0.29^{* * *} \\
(0.00)\end{array}$ & $\begin{array}{l}0.34^{* * *} \\
(0.00)\end{array}$ & $\begin{array}{l}0.26^{* * *} \\
(0.00)\end{array}$ \\
\hline \multicolumn{8}{|c|}{ Averages of time-varying covariates } \\
\hline$\overline{A g e_{i}}$ & & & & & & $\begin{array}{l}0.64^{* * *} \\
(0.01)\end{array}$ & \\
\hline$\overline{\operatorname{Wage}_{i}}$ & & & & & & $\begin{array}{l}-0.16^{* * *} \\
(0.01)\end{array}$ & \\
\hline$\overline{E m p l_{i}}$ & & & & & & $\begin{array}{l}0.15^{* * *} \\
(0.01)\end{array}$ & \\
\hline$\overline{\Delta W a g e_{i}}$ & & & & & & $\begin{array}{l}-0.75^{* * *} \\
(0.02)\end{array}$ & \\
\hline$\overline{\text { Tenure }_{i}}$ & & & & & & $\begin{array}{l}0.13^{* * *} \\
(0.01)\end{array}$ & \\
\hline$\overline{\text { PastEmpl }_{i}}$ & & & & & & $\begin{array}{l}1.24^{* * *} \\
(0.02)\end{array}$ & \\
\hline $1 / \mathrm{A}$ & & & & & $\begin{array}{l}3.08^{(* * *)} \\
(0.02)\end{array}$ & $\begin{array}{l}2.90^{(* * *)} \\
(0.02)\end{array}$ & \\
\hline Constant & $\begin{array}{l}0.29 * * * \\
(0.01)\end{array}$ & $\begin{array}{l}0.37^{* * *} \\
(0.00)\end{array}$ & $\begin{array}{l}-2.19 * * * \\
(0.02)\end{array}$ & & $\begin{array}{l}-0.96^{* * *} \\
(0.02)\end{array}$ & $\begin{array}{l}-3.39^{* * *} \\
(0.05)\end{array}$ & \\
\hline Observations & $1,863,267$ & $1,863,267$ & $1,863,267$ & 889,645 & $1,863,267$ & $1,863,267$ & \\
\hline $\begin{array}{l}\text { RSS in } 1,000 \\
\text { LL in } 1,000\end{array}$ & 1,195 & 123 & $-1,673$ & -768 & -1170 & $-1,167$ & \\
\hline
\end{tabular}

Notes: ${ }^{*} p<0.05,{ }^{* *} p<0.01,{ }^{* * *} p<0.001$. Standard errors based on 100 bootstrap replications (this value was chosen due to very long computing times). Controlling for twins and multiples. ${ }^{(* * *)}$ LR test of $H_{0}: 1 / A=0$ is rejected at a significance level $<0.001$. 
Table A.4: Baseline Results France

\begin{tabular}{|c|c|c|c|c|c|c|c|}
\hline & \multicolumn{2}{|c|}{ Linear } & \multicolumn{5}{|c|}{ Poisson } \\
\hline & OLS & $\mathrm{FE}$ & Pooled & $\mathrm{FE}$ & $\mathrm{RE}$ & $\mathrm{CRE}$ & CRE-ME \\
\hline \multicolumn{8}{|l|}{ Age } \\
\hline $23-27$ & $\begin{array}{l}0.38^{* * *} \\
(0.01)\end{array}$ & $\begin{array}{l}0.22^{* * *} \\
(0.01)\end{array}$ & $\begin{array}{l}1.69 * * * \\
(0.02)\end{array}$ & $\begin{array}{l}1.52^{* * *} \\
(0.03)\end{array}$ & $\begin{array}{l}1.56^{* * *} \\
(0.04)\end{array}$ & $\begin{array}{l}1.51^{* * *} \\
(0.04)\end{array}$ & $\begin{array}{l}0.47^{* * *} \\
(0.01)\end{array}$ \\
\hline $28-32$ & $\begin{array}{l}0.95^{* * *} \\
(0.01)\end{array}$ & $\begin{array}{l}0.64^{* * * *} \\
(0.01)\end{array}$ & $\begin{array}{l}2.41^{* * *} \\
(0.02)\end{array}$ & $\begin{array}{l}2.16^{* * *} \\
(0.04)\end{array}$ & $\begin{array}{l}2.20^{* * *} \\
(0.04)\end{array}$ & $\begin{array}{l}2.12^{* * *} \\
(0.04)\end{array}$ & $\begin{array}{l}1.07^{* * *} \\
(0.01)\end{array}$ \\
\hline $33-37$ & $\begin{array}{l}1.36^{* * *} \\
(0.02)\end{array}$ & $\begin{array}{l}0.85^{* * *} \\
(0.01)\end{array}$ & $\begin{array}{l}2.70^{* * *} \\
(0.02)\end{array}$ & $\begin{array}{l}2.29^{* * *} \\
(0.04)\end{array}$ & $\begin{array}{l}2.35^{* * *} \\
(0.04)\end{array}$ & $\begin{array}{l}2.25^{* * *} \\
(0.04)\end{array}$ & $\begin{array}{l}1.32^{* * *} \\
(0.01)\end{array}$ \\
\hline $38-45$ & $\begin{array}{l}1.58^{* * *} \\
(0.02)\end{array}$ & $\begin{array}{l}0.78^{* * *} \\
(0.01)\end{array}$ & $\begin{array}{l}2.80^{* * *} \\
(0.02)\end{array}$ & $\begin{array}{l}2.19^{* * *} \\
(0.04)\end{array}$ & $\begin{array}{l}2.27^{* * *} \\
(0.04)\end{array}$ & $\begin{array}{l}2.15^{* * *} \\
(0.04)\end{array}$ & $\begin{array}{l}1.23^{* * *} \\
(0.01)\end{array}$ \\
\hline \multicolumn{8}{|l|}{ Education } \\
\hline VT & $\begin{array}{l}-0.00 \\
(0.00)\end{array}$ & & $\begin{array}{l}-0.08 * * * \\
(0.03)\end{array}$ & & $\begin{array}{l}0.04 \\
(0.05)\end{array}$ & $\begin{array}{l}0.06 \\
(0.05)\end{array}$ & $\begin{array}{l}-0.08^{* * *} \\
(0.01)\end{array}$ \\
\hline $\mathrm{TE}$ & $\begin{array}{l}-0.07^{* * *} \\
(0.00)\end{array}$ & & $\begin{array}{l}-2.11^{* * *} \\
(0.05)\end{array}$ & & $\begin{array}{l}-2.09^{* * *} \\
(0.09)\end{array}$ & $\begin{array}{l}-2.01^{* * *} \\
(0.09)\end{array}$ & $\begin{array}{l}-0.19^{* * *} \\
(0.01)\end{array}$ \\
\hline \multicolumn{8}{|c|}{ Education $\times$ Age } \\
\hline $\mathrm{VT} \times 23-27$ & $\begin{array}{l}-0.02^{* *} \\
(0.01)\end{array}$ & $\begin{array}{l}-0.09^{* * *} \\
(0.01)\end{array}$ & $\begin{array}{l}0.02 \\
(0.03)\end{array}$ & $\begin{array}{l}-0.14^{* * *} \\
(0.04)\end{array}$ & $\begin{array}{c}-0.07^{*} \\
(0.04)\end{array}$ & $\begin{array}{c}-0.07^{*} \\
(0.04)\end{array}$ & \\
\hline $\mathrm{TE} \times 23-27$ & $\begin{array}{l}-0.19^{* * *} \\
(0.01)\end{array}$ & $\begin{array}{l}-0.22^{* * *} \\
(0.01)\end{array}$ & $\begin{array}{l}1.10^{* * *} \\
(0.05)\end{array}$ & $\begin{array}{l}1.06^{* * *} \\
(0.07)\end{array}$ & $\begin{array}{l}1.06^{* * *} \\
(0.09)\end{array}$ & $\begin{array}{l}1.07^{* * *} \\
(0.09)\end{array}$ & \\
\hline $\mathrm{VT} \times 28-32$ & $\begin{array}{l}-0.02^{*} \\
(0.01)\end{array}$ & $\begin{array}{l}-0.16^{* * *} \\
(0.01)\end{array}$ & $\begin{array}{l}0.05^{* *} \\
(0.03)\end{array}$ & $\begin{array}{l}-0.23^{* * *} \\
(0.05)\end{array}$ & $\begin{array}{l}-0.13^{* * *} \\
(0.04)\end{array}$ & $\begin{array}{l}-0.13^{* * *} \\
(0.04)\end{array}$ & \\
\hline $\mathrm{TE} \times 28-32$ & $\begin{array}{l}-0.21^{* * *} \\
(0.01)\end{array}$ & $\begin{array}{l}-0.24^{* * *} \\
(0.01)\end{array}$ & $\begin{array}{l}1.79^{* * *} \\
(0.05)\end{array}$ & $\begin{array}{l}1.68^{* * *} \\
(0.08)\end{array}$ & $\begin{array}{l}1.69^{* * *} \\
(0.09)\end{array}$ & $\begin{array}{l}1.70^{* * *} \\
(0.09)\end{array}$ & \\
\hline $\mathrm{VT} \times 33-37$ & $\begin{array}{l}-0.02 \\
(0.02)\end{array}$ & $\begin{array}{l}-0.20^{* * *} \\
(0.02)\end{array}$ & $\begin{array}{l}0.06^{* *} \\
(0.03)\end{array}$ & $\begin{array}{l}-0.27^{* * *} \\
(0.05)\end{array}$ & $\begin{array}{l}-0.16^{* * *} \\
(0.04)\end{array}$ & $\begin{array}{l}-0.15^{* * *} \\
(0.04)\end{array}$ & \\
\hline $\mathrm{TE} \times 33-37$ & $\begin{array}{l}-0.12^{* * *} \\
(0.02)\end{array}$ & $\begin{array}{l}-0.11^{* * *} \\
(0.02)\end{array}$ & $\begin{array}{l}1.99 * * * \\
(0.05)\end{array}$ & $\begin{array}{l}1.88^{* * *} \\
(0.08)\end{array}$ & $\begin{array}{l}1.89^{* * *} \\
(0.09)\end{array}$ & $\begin{array}{l}1.90^{* * *} \\
(0.09)\end{array}$ & \\
\hline $\mathrm{VT} \times 38-45$ & $\begin{array}{l}-0.08^{* * *} \\
(0.02)\end{array}$ & $\begin{array}{l}-0.21^{* * *} \\
(0.02)\end{array}$ & $\begin{array}{l}0.04 \\
(0.03)\end{array}$ & $\begin{array}{l}-0.27^{* * *} \\
(0.05)\end{array}$ & $\begin{array}{l}-0.15^{* * *} \\
(0.04)\end{array}$ & $\begin{array}{l}-0.14^{* * *} \\
(0.04)\end{array}$ & \\
\hline $\mathrm{TE} \times 38-45$ & $\begin{array}{l}-0.13^{* * *} \\
(0.02)\end{array}$ & $\begin{array}{l}-0.01 \\
(0.02)\end{array}$ & $\begin{array}{l}2.01^{* * *} \\
(0.05)\end{array}$ & $\begin{array}{l}1.95^{* * *} \\
(0.08)\end{array}$ & $\begin{array}{l}1.95^{* * *} \\
(0.09)\end{array}$ & $\begin{array}{l}1.96^{* * *} \\
(0.09)\end{array}$ & \\
\hline Employment & & & & & & & \\
\hline Part-time & $\begin{array}{l}0.20^{* * *} \\
(0.01)\end{array}$ & $\begin{array}{l}0.06^{* * *} \\
(0.00)\end{array}$ & $\begin{array}{l}0.19^{* * *} \\
(0.00)\end{array}$ & $\begin{array}{l}0.07^{* * *} \\
(0.00)\end{array}$ & $\begin{array}{l}0.08^{* * *} \\
(0.00)\end{array}$ & $\begin{array}{l}0.07^{* * *} \\
(0.00)\end{array}$ & $\begin{array}{l}0.06^{* * *} \\
(0.00)\end{array}$ \\
\hline Full-time & $\begin{array}{l}-0.11^{* * *} \\
(0.01)\end{array}$ & $\begin{array}{l}-0.05^{* * *} \\
(0.00)\end{array}$ & $\begin{array}{l}-0.06^{* * *} \\
(0.00)\end{array}$ & $\begin{array}{l}0.03^{* * *} \\
(0.00)\end{array}$ & $\begin{array}{l}0.02^{* * *} \\
(0.00)\end{array}$ & $\begin{array}{l}0.03^{* * *} \\
(0.00)\end{array}$ & $\begin{array}{l}-0.02^{* * *} \\
(0.00)\end{array}$ \\
\hline Past Employ & nent & & & & & & \\
\hline
\end{tabular}

Continued on next page 


\begin{tabular}{|c|c|c|c|c|c|c|c|}
\hline & \multicolumn{2}{|c|}{ Linear } & \multicolumn{5}{|c|}{ Poisson } \\
\hline & OLS & $\mathrm{FE}$ & Pooled & $\mathrm{FE}$ & $\mathrm{RE}$ & $\mathrm{CRE}$ & CRE-ME \\
\hline Not empl. & $\begin{array}{l}0.02^{* * *} \\
(0.00)\end{array}$ & $\begin{array}{l}0.02^{* * *} \\
(0.00)\end{array}$ & $\begin{array}{l}0.01^{* * *} \\
(0.00)\end{array}$ & $\begin{array}{l}-0.01 * * * \\
(0.00)\end{array}$ & $\begin{array}{l}-0.01^{* * *} \\
(0.00)\end{array}$ & $\begin{array}{l}-0.01^{* * *} \\
(0.00)\end{array}$ & $\begin{array}{l}-0.02^{* * *} \\
(0.00)\end{array}$ \\
\hline \multicolumn{8}{|l|}{ Wage } \\
\hline $25-49 \%$ & $\begin{array}{l}0.00 \\
(0.01)\end{array}$ & $\begin{array}{l}-0.02^{* * *} \\
(0.00)\end{array}$ & $\begin{array}{l}-0.02^{* * *} \\
(0.00)\end{array}$ & $\begin{array}{l}-0.04^{* * *} \\
(0.00)\end{array}$ & $\begin{array}{l}-0.04^{* * *} \\
(0.00)\end{array}$ & $\begin{array}{l}-0.04^{* * *} \\
(0.00)\end{array}$ & $\begin{array}{l}-0.05^{* * *} \\
(0.00)\end{array}$ \\
\hline $50-74 \%$ & $\begin{array}{l}-0.07^{* * *} \\
(0.01)\end{array}$ & $\begin{array}{l}-0.04^{* * *} \\
(0.00)\end{array}$ & $\begin{array}{l}-0.07^{* * *} \\
(0.00)\end{array}$ & $\begin{array}{l}-0.05^{* * *} \\
(0.00)\end{array}$ & $\begin{array}{l}-0.05^{* * *} \\
(0.00)\end{array}$ & $\begin{array}{l}-0.05^{* * *} \\
(0.00)\end{array}$ & $\begin{array}{l}-0.06^{* * *} \\
(0.00)\end{array}$ \\
\hline $75-89 \%$ & $\begin{array}{l}-0.13^{* * *} \\
(0.01)\end{array}$ & $\begin{array}{l}-0.06^{* * *} \\
(0.00)\end{array}$ & $\begin{array}{l}-0.12^{* * *} \\
(0.00)\end{array}$ & $\begin{array}{l}-0.04^{* * *} \\
(0.00)\end{array}$ & $\begin{array}{l}-0.06^{* * *} \\
(0.00)\end{array}$ & $\begin{array}{l}-0.04^{* * *} \\
(0.00)\end{array}$ & $\begin{array}{l}-0.07^{* * *} \\
(0.00)\end{array}$ \\
\hline $90-94 \%$ & $\begin{array}{l}-0.21^{* * *} \\
(0.01)\end{array}$ & $\begin{array}{l}-0.08^{* * *} \\
(0.00)\end{array}$ & $\begin{array}{l}-0.17^{* * *} \\
(0.01)\end{array}$ & $\begin{array}{l}-0.04^{* * *} \\
(0.00)\end{array}$ & $\begin{array}{l}-0.07^{* * *} \\
(0.00)\end{array}$ & $\begin{array}{l}-0.04^{* * *} \\
(0.00)\end{array}$ & $\begin{array}{l}-0.07^{* * *} \\
(0.00)\end{array}$ \\
\hline $95-98 \%$ & $\begin{array}{l}-0.23^{* * *} \\
(0.02)\end{array}$ & $\begin{array}{l}-0.07^{* * *} \\
(0.01)\end{array}$ & $\begin{array}{l}-0.18^{* * *} \\
(0.01)\end{array}$ & $\begin{array}{l}-0.01^{* *} \\
(0.01)\end{array}$ & $\begin{array}{l}-0.04^{* * *} \\
(0.01)\end{array}$ & $\begin{array}{l}-0.01^{* *} \\
(0.01)\end{array}$ & $\begin{array}{l}-0.04^{* * *} \\
(0.01)\end{array}$ \\
\hline $99-100 \%$ & $\begin{array}{l}-0.21^{* * *} \\
(0.03)\end{array}$ & $\begin{array}{l}-0.03^{* * *} \\
(0.01)\end{array}$ & $\begin{array}{l}-0.15^{* * *} \\
(0.01)\end{array}$ & $\begin{array}{l}0.02^{* * *} \\
(0.01)\end{array}$ & $\begin{array}{l}-0.01 \\
(0.01)\end{array}$ & $\begin{array}{l}0.03^{* * *} \\
(0.01)\end{array}$ & $\begin{array}{l}-0.00^{* * *} \\
(0.01)\end{array}$ \\
\hline \multicolumn{8}{|c|}{ Wage Increase } \\
\hline$>0$ & $\begin{array}{l}-0.02^{* * *} \\
(0.00)\end{array}$ & $\begin{array}{l}-0.04^{* * *} \\
(0.00)\end{array}$ & $\begin{array}{l}-0.03^{* * *} \\
(0.00)\end{array}$ & $\begin{array}{l}-0.05^{* * *} \\
(0.00)\end{array}$ & $\begin{array}{l}-0.05^{* * *} \\
(0.00)\end{array}$ & $\begin{array}{l}-0.05^{* * *} \\
(0.00)\end{array}$ & $\begin{array}{l}-0.08^{* * *} \\
(0.00)\end{array}$ \\
\hline$>$ median & $\begin{array}{l}0.02^{* * *} \\
(0.00)\end{array}$ & $\begin{array}{l}0.01^{* * *} \\
(0.00)\end{array}$ & $\begin{array}{l}0.04^{* * *} \\
(0.00)\end{array}$ & $\begin{array}{l}0.01^{* * *} \\
(0.00)\end{array}$ & $\begin{array}{l}0.01^{* * *} \\
(0.00)\end{array}$ & $\begin{array}{l}0.01^{* * *} \\
(0.00)\end{array}$ & $\begin{array}{l}-0.05^{* * *} \\
(0.00)\end{array}$ \\
\hline \multicolumn{8}{|c|}{ Tenure in months } \\
\hline $6-11$ & $\begin{array}{l}0.00 \\
(0.00)\end{array}$ & $\begin{array}{l}-0.02^{* * *} \\
(0.00)\end{array}$ & $\begin{array}{l}-0.02^{* * *} \\
(0.01)\end{array}$ & $\begin{array}{l}-0.02^{* * *} \\
(0.00)\end{array}$ & $\begin{array}{l}-0.02^{* * *} \\
(0.00)\end{array}$ & $\begin{array}{l}-0.02^{* * *} \\
(0.00)\end{array}$ & $\begin{array}{l}-0.02^{* * *} \\
(0.00)\end{array}$ \\
\hline $12-23$ & $\begin{array}{l}0.08^{* * *} \\
(0.00)\end{array}$ & $\begin{array}{l}0.05^{* * *} \\
(0.00)\end{array}$ & $\begin{array}{l}0.06^{* * *} \\
(0.00)\end{array}$ & $\begin{array}{l}0.01^{* * * *} \\
(0.00)\end{array}$ & $\begin{array}{l}0.02^{* * *} \\
(0.00)\end{array}$ & $\begin{array}{l}0.01^{* * * *} \\
(0.00)\end{array}$ & $\begin{array}{l}0.03^{* * *} \\
(0.00)\end{array}$ \\
\hline $24-35$ & $\begin{array}{l}0.09 * * * \\
(0.00)\end{array}$ & $\begin{array}{l}0.05^{* * *} \\
(0.00)\end{array}$ & $\begin{array}{l}0.09^{* * *} \\
(0.00)\end{array}$ & $\begin{array}{l}0.03^{* * *} \\
(0.00)\end{array}$ & $\begin{array}{l}0.04^{* * *} \\
(0.00)\end{array}$ & $\begin{array}{l}0.04^{* * *} \\
(0.00)\end{array}$ & $\begin{array}{l}0.06^{* * *} \\
(0.00)\end{array}$ \\
\hline$\geq 36$ & $\begin{array}{l}0.11^{* * *} \\
(0.01)\end{array}$ & $\begin{array}{l}0.05^{* * *} \\
(0.00)\end{array}$ & $\begin{array}{l}0.13^{* * *} \\
(0.00)\end{array}$ & $\begin{array}{l}0.07^{* * *} \\
(0.00)\end{array}$ & $\begin{array}{l}0.08^{* * *} \\
(0.00)\end{array}$ & $\begin{array}{l}0.08^{* * *} \\
(0.00)\end{array}$ & $\begin{array}{l}0.11^{* * *} \\
(0.00)\end{array}$ \\
\hline Occupation & Choice & & & & & & \\
\hline Teacher & $\begin{array}{l}-0.12^{* * *} \\
(0.02)\end{array}$ & $\begin{array}{l}-0.00 \\
(0.01)\end{array}$ & $\begin{array}{l}-0.11^{* * *} \\
(0.01)\end{array}$ & $\begin{array}{l}0.03^{* * *} \\
(0.01)\end{array}$ & $\begin{array}{l}-0.01 \\
(0.01)\end{array}$ & $\begin{array}{l}-0.04^{* * *} \\
(0.01)\end{array}$ & $\begin{array}{l}-0.04^{* * *} \\
(0.01)\end{array}$ \\
\hline Cohort & & & & & & & \\
\hline $1959-68$ & $\begin{array}{l}-0.19^{* * *} \\
(0.01)\end{array}$ & & $\begin{array}{l}-0.12^{* * *} \\
(0.00)\end{array}$ & & $\begin{array}{l}-0.28^{* * *} \\
(0.01)\end{array}$ & $\begin{array}{l}-0.10^{* * *} \\
(0.01)\end{array}$ & $\begin{array}{l}-0.11^{* * *} \\
(0.01)\end{array}$ \\
\hline 1969-78 & $\begin{array}{l}-0.40^{* * *} \\
(0.02)\end{array}$ & & $\begin{array}{l}-0.30^{* * *} \\
(0.01)\end{array}$ & & $\begin{array}{l}-0.74^{* * *} \\
(0.01)\end{array}$ & $\begin{array}{l}-0.03 \\
(0.02)\end{array}$ & $\begin{array}{l}-0.03 \\
(0.02)\end{array}$ \\
\hline 1979-89 & $\begin{array}{l}-0.47^{* * *} \\
(0.02)\end{array}$ & & $\begin{array}{l}-0.57^{* * *} \\
(0.01)\end{array}$ & & $\begin{array}{l}-1.28^{* * *} \\
(0.02)\end{array}$ & $\begin{array}{l}-0.19^{* * *} \\
(0.03)\end{array}$ & $\begin{array}{l}-0.20^{* * *} \\
(0.03)\end{array}$ \\
\hline
\end{tabular}

Continued on next page 


\begin{tabular}{|c|c|c|c|c|c|c|c|}
\hline & \multicolumn{2}{|c|}{ Linear } & \multicolumn{5}{|c|}{ Poisson } \\
\hline & OLS & $\mathrm{FE}$ & Pooled & $\mathrm{FE}$ & $\mathrm{RE}$ & $\mathrm{CRE}$ & CRE-ME \\
\hline \multicolumn{8}{|l|}{ Year } \\
\hline 1997-1999 & $\begin{array}{l}-0.01^{* * *} \\
(0.00)\end{array}$ & $\begin{array}{l}0.10^{* * *} \\
(0.00)\end{array}$ & $\begin{array}{l}-0.03^{* * *} \\
(0.00)\end{array}$ & $\begin{array}{l}0.06^{* * *} \\
(0.00)\end{array}$ & $\begin{array}{l}0.05^{* * *} \\
(0.00)\end{array}$ & $\begin{array}{l}0.06^{* * *} \\
(0.00)\end{array}$ & $\begin{array}{l}0.05^{* * *} \\
(0.00)\end{array}$ \\
\hline 2000-2002 & $\begin{array}{l}0.02^{* * *} \\
(0.00)\end{array}$ & $\begin{array}{l}0.23^{* * *} \\
(0.00)\end{array}$ & $\begin{array}{l}-0.00 \\
(0.00)\end{array}$ & $\begin{array}{l}0.16^{* * *} \\
(0.00)\end{array}$ & $\begin{array}{l}0.14^{* * *} \\
(0.00)\end{array}$ & $\begin{array}{l}0.16^{* * *} \\
(0.00)\end{array}$ & $\begin{array}{l}0.16^{* * *} \\
(0.00)\end{array}$ \\
\hline 2003-2005 & $\begin{array}{l}0.07^{* * *} \\
(0.01)\end{array}$ & $\begin{array}{l}0.37^{* * *} \\
(0.00)\end{array}$ & $\begin{array}{l}0.05^{* * *} \\
(0.00)\end{array}$ & $\begin{array}{l}0.28^{* * *} \\
(0.00)\end{array}$ & $\begin{array}{l}0.25^{* * *} \\
(0.00)\end{array}$ & $\begin{array}{l}0.28^{* * *} \\
(0.00)\end{array}$ & $\begin{array}{l}0.30^{* * *} \\
(0.00)\end{array}$ \\
\hline 2006-2007 & $\begin{array}{l}0.09 * * * \\
(0.01)\end{array}$ & $\begin{array}{l}0.49^{* * *} \\
(0.00)\end{array}$ & $\begin{array}{l}0.07^{* * *} \\
(0.00)\end{array}$ & $\begin{array}{l}0.39^{* * *} \\
(0.00)\end{array}$ & $\begin{array}{l}0.34^{* * *} \\
(0.00)\end{array}$ & $\begin{array}{l}0.38^{* * *} \\
(0.00)\end{array}$ & $\begin{array}{l}0.43^{* * *} \\
(0.00)\end{array}$ \\
\hline \multicolumn{8}{|c|}{ Averages of time-varying covariates } \\
\hline$\overline{A g e_{i}}$ & & & & & & $\begin{array}{l}0.34^{* * *} \\
(0.01)\end{array}$ & \\
\hline$\overline{\operatorname{Wage}_{i}}$ & & & & & & $\begin{array}{l}-0.11^{* * *} \\
(0.00)\end{array}$ & \\
\hline$\overline{E m p l_{i}}$ & & & & & & $\begin{array}{l}-0.42^{* * *} \\
(0.01)\end{array}$ & \\
\hline$\overline{\Delta W a g e_{i}}$ & & & & & & $\begin{array}{l}-0.51^{* * *} \\
(0.02)\end{array}$ & \\
\hline$\overline{\text { Tenure }_{i}}$ & & & & & & $\begin{array}{l}0.13^{* * *} \\
(0.01)\end{array}$ & \\
\hline$\overline{\text { PastEmpl }_{i}}$ & & & & & & $\begin{array}{l}-0.22^{* * *} \\
(0.03)\end{array}$ & \\
\hline $1 / \mathrm{A}$ & & & & & $\begin{array}{l}1.30^{(* * *)} \\
(0.01)\end{array}$ & $\begin{array}{l}1.25^{(* * *)} \\
(0.01)\end{array}$ & \\
\hline Constant & $\begin{array}{l}0.38^{* * *} \\
(0.02)\end{array}$ & $\begin{array}{l}0.37^{* * *} \\
(0.00)\end{array}$ & $\begin{array}{l}-2.19^{* * *} \\
(0.02)\end{array}$ & & $\begin{array}{l}-1.63^{* * *} \\
(0.04)\end{array}$ & $\begin{array}{l}-2.03^{* * *} \\
(0.05)\end{array}$ & \\
\hline Observations & $1,155,439$ & $1,155,439$ & $1,155,439$ & 813,637 & $1,155,439$ & $1,155,439$ & \\
\hline RSS in 1,000 & 985 & 142 & & & & & \\
\hline LL in 1,000 & & & $-1,289$ & -717 & $-1,032$ & $-1,031$ & \\
\hline
\end{tabular}

Notes: ${ }^{*} p<0.05,{ }^{* *} p<0.01,{ }^{* * *} p<0.001$. Standard errors based on 100 bootstrap replications (this value was chosen due to very long computing times). Controlling for twins and multiples. ${ }^{(* * *)}$ LR test of $H_{0}: 1 / A=0$ is rejected at a significance level $<0.001$. 


\section{A.II: Data Preparation and Estimation Samples}

In order to improve the comparability of both data sets and to reduce issues of non-random selection, the same sample-selection criteria are applied to both data sources. While we have complete information about the dates of giving birth in both data sets, information about the labour market state and the related administrative variables are missing for some time periods. The first step is to create a balanced yearly panel structure. However, the data only covers the period up to 2007 such that some women remain right-censored. In the resulting panel, each female has complete records from 18 years old to $\max \left(45, \operatorname{age}_{i, 2007}\right)$. We create variables that capture the time periods without administrative records and define missing periods as non-employment. Time-constant variables and variables that depend on calendar time only are completed from records of other periods. Given that birthdays of children are always observed, the number of children in year $t$ can be created for all periods. Unlike all other variables, $y_{i t}$ refers to the upcoming year, e.g. the number of children which will be born between $t$ and $t+1$. This is reasonable because we study the impact of current or past factors on current or future fertility.

If there are parallel records for the same individual, the employment record with employment subject to social-security is always kept. If two parallel periods of dependent employment are recorded, the record with the higher labour income is kept and the wage of the lower paid income is added to it. Periods of employment subject to social-security are always kept in favour of any other parallel record. Note that for now, periods are recorded on a daily and not on a yearly basis. In order to obtain a panel on a yearly basis, we condition on the $31^{\text {st }}$ of May: we only use the information available on this specific day. The choice of this date is arbitrary but avoids the summer months, the time around the turn of the year and other typical dates for changing the state of employment. Robustness checks are performed using different cut-off dates to acknowledge the possibility of non-random selection. The resulting panel contains 242,987 women in Germany and 156,512 in France (Panel 1 in Table A.5). Finally, individuals with missing information on education are dropped and the German data is restricted to women with at least one period of dependent employment, since only those individuals are contained in the French data. The resulting sample for the estimations therefore contains 173,843 females for Germany and 102,574 females for France (Panel 2). To further harmonise the data structure, some employment information for Ger- 
many is recoded. All periods during which the individual is not dependently employed in Germany are classified as non-observed as it is the case in the French data.

Table A.5: Data dimensions after different data preparation steps

\begin{tabular}{ll|rr}
\hline \hline & & Panel 1 & Panel 2 \\
\hline Germany & $N$ & 242,987 & 173,843 \\
& $\sum_{i=1}^{N} T_{i}$ & $2,572,810$ & $1,895,629$ \\
\hline France & $N$ & 156,512 & 102,574 \\
& $\sum_{i=1}^{N} T_{i}$ & $1,575,165$ & $1,155,439$ \\
\hline \hline
\end{tabular}

Descriptive statistics for the explanatory variables are given in Table A.2. We use the highest life-time educational achievement for each female for our analysis. For years preceding its attainment, this variable can be interpreted as expected educational degree. Following Arntz et al. (2017) and Lauer and Weber (2003), we group education information into three categories: having no educational achievement (no VT), having completed a vocational training (VT) and holding a tertiary education diploma (TE). The education information is corrected using the imputation procedure number 1 of Fitzenberger et al. (2006) but allowing only for three instead of six possible outcomes. Due to the different education systems in both countries, in particular with respect to professional education, the estimated education parameters need to be interpreted cautiously. To control at least partly for job choice, an indicator is created for professions with a high child-amenity value. As a simplified proxy, we use primary and nursery school teachers. These professions are unambiguously identifiable in both data sets and empirical evidence by Hoem et al. (2006) indicates that teachers indeed have low levels of childlessness and high ultimate fertility rates. Tenure is defined as continuous employment at the same company, regardless of changes in working hours, work contract, salary or position. Interruptions in the form of non-employment or employment at another firm for up to 180 days are allowed. A woman is said to have experienced non-employment during the past 365 days if she has remained unobserved for more than 28 days. For the supplementary country-specific regression for Germany, periods of non-employment are broken up into periods of registered unemployment, of official inactivity and non-observation. Registered inactivity refers to periods of sickness, incapacity to work, maternity, child-rearing, household, non-profit care giving and voluntary pension insurance. Persons insure themselves voluntarily for two main reasons: either because they are self-employed and judge the insurance to be beneficial or because 
they seek an entitlement to a statutory old-age pension by contributing during periods of inactivity. To be categorized as inactive, the second option is used by additionally requiring the salary to be zero during the period of voluntary insurance.

\section{A.III Poisson Panel Models}

In this Appendix we describe different panel estimators for Poisson regression. The starting point are equations (1) and (2) as given in Section 5. A first approach is to use a pooled maximum likelihood estimator that applies the usual cross sectional model to all person and year observations (pooled sample). Pooled estimation is consistent if

$$
E\left[y_{i t} \mid \boldsymbol{x}_{i t}\right]=a \lambda_{i t}=a \exp \left(\boldsymbol{x}_{i t} \boldsymbol{\beta}\right)
$$

with $a=E\left[a_{i}\right]$ and $a_{i}$ statistically independent of $\boldsymbol{x}_{i t}, t=1, \ldots, T_{i}$. The Poisson distribution and condition (5) imply equidispersion: $\operatorname{Var}\left[y_{i t} \mid \boldsymbol{x}_{i t}, a_{i}\right]=E\left[y_{i t} \mid \boldsymbol{x}_{i t}, a_{i}\right]$, which tends not to fit the data. Overdispersion in the data will not harm consistency of the estimates but ML estimation will produce incorrect standard errors. Robust standard errors should be adopted to account for the possibility of overdispersion. A line of research especially focuses on models that account for over- and underdispersion (Wang and Famoye, 1997; Melkersson and Rooth, 2000). Another problem is a misspecification of the conditional distribution due to serial dependence, e.g. the possibility of $y_{i t}$ and $y_{i r}, t \neq r$ not being independent conditional on $\boldsymbol{x}_{i}$ and $a_{i}$. We address this issue by using clustered standard errors, where clustering takes place on the individual level.

The availability of panel data permits the modelling of unobserved individual features in addition to the usual error term. We consider random and fixed effects models which are assumed to satisfy

$$
\begin{array}{r}
E\left[y_{i t} \mid \boldsymbol{x}_{i 1}, \ldots, \boldsymbol{x}_{i T_{i}}, a_{i}\right]=E\left[y_{i t} \mid \boldsymbol{x}_{i t}, a_{i}\right], \quad t=1, \ldots, T_{i} \\
\operatorname{Pr}\left(y_{i 1}, \ldots y_{i T_{i}} \mid \boldsymbol{x}_{i}, a_{i}\right)=\prod_{t=1}^{T_{i}} \operatorname{Pr}\left(y_{i t} \mid \boldsymbol{x}_{i}, a_{i}\right) .
\end{array}
$$

with $\boldsymbol{x}_{i}=\left(x_{i 1}, \ldots, x_{i T_{i}}\right)$. Equation (6) defines strict exogeneity of $\boldsymbol{x}_{i t}$ conditional on $a_{i}$, while Equation (7) defines independence of the dependent variable over time conditional on 
$\boldsymbol{x}_{i}$ and $a_{i}$. The strict exogeneity assumption rules out lagged values of $y_{i t}$ as explanatory variables, which is plausible according to our theoretical model. Moreover, it does not permit for feedback effects from the idiosyncratic error term on future regressors. The conditional joint density for individual $i$ is obtained by integrating out the unobserved individual-specific effect:

$$
\operatorname{Pr}\left(y_{i 1}, \ldots, y_{i T_{i}} \mid \boldsymbol{x}_{i}\right)=\int_{0}^{\infty} \operatorname{Pr}\left(y_{i 1}, \ldots, y_{i T} \mid \boldsymbol{x}_{i}, a_{i}\right) f\left(a_{i} \mid \boldsymbol{x}_{i}\right) d a_{i}
$$

Assuming $a_{i}$ to be iid distributed and hence uncorrelated with the regressors defines the random effects model, which strongly simplifies the estimation via ML but whose estimation results are sensitive to violations of this assumption. In the Poisson model with Gammadistributed random effects, $a_{i}$ is assumed to be iid and to follow a $\operatorname{Gamma}(A, A)$ distribution with $E\left[a_{i}\right]=1$ and $\operatorname{Var}\left[a_{i}\right]=1 / A$. The parameter $A$ is estimated along with the $\beta$. As derived in Cameron and Trivedi (2013, p.361), the joint density (8) becomes:

$\operatorname{Pr}\left(y_{i 1}, \ldots, y_{i T} \mid \boldsymbol{x}_{i}\right)=\prod_{t=1}^{T_{i}} \frac{\lambda_{i t}^{y_{i t}}}{y_{i t} !} \times\left(\frac{A}{\sum_{t=1}^{T_{i}} \lambda_{i t}+A}\right)^{A} \times\left(\sum_{t=1}^{T_{i}} \lambda_{i t}+A\right)^{-\sum_{t=1}^{T_{i}} y_{i t}} \frac{\Gamma\left(\sum_{t=1}^{T_{i}} y_{i t}+A\right)}{\Gamma(A)}$.

This extension now allows for overdispersion, since $E\left[y_{i t} \mid \boldsymbol{x}_{i t}\right]=\lambda_{i t}$ and $\operatorname{Var}\left[y_{i t} \mid \boldsymbol{x}_{i t}\right]=\lambda_{i t}+$ $\lambda_{i t}^{2} / A$.

If $E\left[a_{i} \mid x_{i 1}, \ldots, x_{i T}\right] \neq E\left[a_{i}\right]$ or if condition (5) is not met, pooled ML estimation and the random effects model will be inconsistent. In this case, the fixed effects approach may be more appropriate as it allows for arbitrary dependence between $\boldsymbol{x}_{i}$ and $a_{i}$.

For the Poisson model with multiplicative fixed effects, there are three different approaches for estimation (Cameron and Trivedi, 2013, chapter 9.4): (i) moment-based estimation eliminating the fixed effect by mean differencing similar to the linear model. (ii) Joint estimation of $\beta$ and $a_{i}$ via ML. Here no incidental parameter bias occurs since $a_{i}$ drops out of the concentrated likelihood function and (iii) conditional ML estimation of $\beta$ conditional on a sufficient statistic for the individual effects. We use the third approach by applying the method of Andersen (1970). Palmgren (1981) and Hausman, Hall and Griliches (HHG, 1984) have shown that the log-likelihood of the fixed effects Poisson model conditional on the individual sum of counts $k_{i}=\sum_{t=1}^{T_{i}} y_{i t}$ does not depend on $a_{i}$. Given (1) 
and (2), the conditional joint density for individual $i$ becomes

$$
\operatorname{Pr}\left(y_{i 1}, \ldots, y_{i T_{i}} \mid \boldsymbol{x}_{i}, \sum_{t=1}^{T_{i}} y_{i t}\right)=\frac{\left(\sum_{t}^{T_{i}} y_{i t}\right) !}{\prod_{t}^{T_{i}} y_{i t} !} \times \prod_{t=1}^{T_{i}}\left(\frac{a_{i} \lambda_{i t}}{\sum_{s} a_{i} \lambda_{i s}}\right)^{y_{i t}}
$$

which results in the conditional population log-likelihood function

$$
\mathcal{L}_{c}(\boldsymbol{\beta})=\sum_{i=1}^{N}\left[\ln \left(\sum_{t=1}^{T_{i}} y_{i t}\right) !-\sum_{t=1}^{T_{i}} \ln \left(y_{i t} !\right)+\sum_{t=1}^{T_{i}} y_{i t} \ln \left(\frac{\lambda_{i t}}{\sum_{s=1}^{T_{i}} \lambda_{i s}}\right)\right]
$$

The conditional ML estimator $\hat{\boldsymbol{\beta}}^{F E}$ maximises this function.

The fixed effects Poisson estimator is consistent for $\beta$ as long as assumption (1) is satisfied (Wooldridge, 1999). This leaves both the marginal distribution of $a_{i}$ and the conditional distribution of $y_{i}$ given $\boldsymbol{x}_{i}$ completely unrestricted and hereby allows for any mean-variance relationship of $y_{i t}$ and for dependence between $y_{i t}$ and $y_{i r}, t \neq r$. Both the fixed and the random effects model require cluster-robust standard errors to account for within cluster correlation, which are implemented using cluster bootstraps (for more details see Cameron and Trivedi, 2010).

The fixed effects Poisson estimation has two main drawbacks: on the one hand, coefficients of time-invariant variables are not identified. ${ }^{2}$ On the other hand, marginal effects wrt $\boldsymbol{x}_{i t}$ cannot be computed because they depend on the $a_{i}$ which are also left unidentified. In the random effects model, average marginal effects are well defined since the individual effect is multiplicative, uncorrelated with the exogenous variables and satisfies $E\left[a_{i}\right]=1$. However, the random effects approach produces inconsistent results if the individual effect is correlated with the explanatory variables. As intermediate between both models, $a_{i}$ can be seen as conditionally correlated with $\boldsymbol{x}_{i t}$. This idea was originally formulated by Mundlak (1978) and Chamberlain $(1980,1982)$ for the linear case. In the correlated random effects (CRE) model (Cameron and Trivedi, 2013, chapter 9.5.4), the individual effect is specified as

$$
a_{i}=\exp \left(\overline{\boldsymbol{x}}_{i} \boldsymbol{\xi}+\epsilon_{i}\right)
$$

\footnotetext{
${ }^{2}$ Actually, the HHG framework yields estimates for the parameters of the time-invariant covariates, a feature that is not common for fixed effects models. For further explanations see Allison and Waterman (2002).
} 
where $\overline{\boldsymbol{x}}_{i}$ denotes the vector of time averages of the time-varying covariates and $\epsilon_{i}$ is an iid error term. The first summand in the exponential captures the correlation between $a_{i}$ and the regressors, while $\epsilon_{i}$ is required to be independent of the regressors. In this specification, the effect of time-constant variables cannot be distinguished from $a_{i}$ unless time-constant variables are uncorrelated with the individual effect. If this is the case, time-constant variables are not included in $\overline{\boldsymbol{x}}_{i}$ and their partial effect can be estimated. Plugging (12) into (1) yields

$$
E\left[y_{i t} \mid \boldsymbol{x}_{i t}, a_{i}\right]=\exp \left(\boldsymbol{x}_{i t} \boldsymbol{\beta}+\overline{\boldsymbol{x}}_{i} \boldsymbol{\xi}+\epsilon_{i}\right) \quad .
$$

If $\boldsymbol{\xi} \neq 0$, there is correlation between $a_{i}$ and $\boldsymbol{x}_{i t}$ and the application of a CRE model instead of a simple RE model is appropriate. Assuming $\exp \left(\epsilon_{i}\right) \stackrel{i i d}{\sim} \operatorname{Gamma}(A, A)$, the expected count simplifies to

$$
E\left[y_{i t} \mid \boldsymbol{x}_{i t}, a_{i}\right]=\exp \left(\boldsymbol{x}_{i t} \boldsymbol{\beta}+\overline{\boldsymbol{x}}_{i} \boldsymbol{\xi}\right)
$$

with $\boldsymbol{x}_{i t}$ including an intercept. This is a Poisson-Gamma RE model with $\overline{\boldsymbol{x}}_{i}$ as additional regressors. The equivalent of the marginal effects in (4) are

$$
M E_{j}=\frac{\partial E\left[y_{i t} \mid \boldsymbol{x}_{i t}, a_{i}\right]}{\partial x_{i t j}}=\beta_{j} E\left[y_{i t} \mid \boldsymbol{x}_{i t}, a_{i}\right]+\frac{1}{T_{i}} \xi_{j} E\left[y_{i t} \mid \boldsymbol{x}_{i t}, a_{i}\right]
$$

In our empirical analysis we compute average marginal effects, which are sample averages of differences in estimated conditional expectations when one of the regressors increases by one unit. This is more adequate for discrete regressors and more convenient in the presence of interaction terms. For more details, and related references for the Poisson count models for panel data, see the textbooks by Cameron and Trivedi (2013) and Wooldridge (2010).

In the remainder of this section, we discuss the appropriateness of applying the above model to the fertility context. As outlined in Section 4, the data is count data and includes personal information on the individual, her current job, her employment history and control variables but does not exhaustively include all variables that play a role in fertility. For example, our economic framework presented in the supplementary material S.I comprises the unobserved personal preference for children, and family policy variables. These are likely to simultaneously affect fertility behaviour and female employment characteristics but are 
unavailable in the data. Therefore, disregarding them may induce an estimation bias. In order to mitigate this issue we exploit the panel structure of the data by allowing individual effects $a_{i}$ that capture any time-constant information of the omitted variables. The individual-specific effect can also include time-constant attributes of the partner. His income is also likely to be correlated with female education and income. The inclusion of correlated $a_{i}$ terms also addresses simultaneity issues that are due to interrelated employment and fertility decisions. Suppose the fertility equation can be reduced to $y_{i t}=\boldsymbol{x}_{i t} \boldsymbol{\beta}_{\mathbf{1}}+\boldsymbol{z}_{1, i t} \boldsymbol{\beta}_{\mathbf{2}}+u_{1, i t}$, with $\boldsymbol{x}_{i t}$ denoting a vector of employment characteristics, $\boldsymbol{z}_{1, i t}$ a vector of control variables and $u_{1, i t}$ the error term comprising the individual-specific effect $a_{i}$ and an idiosyncratic error term $\epsilon_{1, i t}$. Employment characteristics depend on past fertility outcomes. For instance for the $j$ 'th variable $x_{j i t}=y_{i, t-1} \alpha_{1}+\boldsymbol{z}_{2, i t} \boldsymbol{\alpha}_{\mathbf{2}}+u_{2, i t}$, with $\boldsymbol{z}_{2, i t}$ a vector of relevant control variables and $u_{2, i t}$ an error term including the same individual-specific effect $a_{i}$ and an idiosyncratic error term $\epsilon_{2, i t}$. This relationship introduces some correlation between $u_{1, i t}$ and $x_{j i t}$, so that in order to consistently estimate the parameters of the fertility equation for $y_{i t}$, we need to control for the relationship between $\boldsymbol{x}_{i t}$ and $u_{1, i t}$. By applying a CRE or FE model, we can condition on $a_{i}$ and allow hereby for possible unconditional correlations between fertility and employment decisions (simultaneity). Only the remaining variation due to the idiosyncratic error terms $\epsilon_{1, i t}$ and $\epsilon_{2, i t}$ are required to be uncorrelated, otherwise the CRE and FE models are inconsistently estimated.

The validity of the RE, FE and CRE models is sensitive to violations of the strict exogeneity assumption. First, in order to satisfy this assumption, the past number of children cannot be included in the regression. If past fertility outcomes affect both current employment characteristics and the current number of children, the omission of $y_{i, t-1}$ will induce a bias. As discussed above, past fertility is acknowledged to have an impact on employment characteristics, resulting in a correlation between $u_{1, i t}$ and at least one regressor. However, we claim the dependent variable to be entirely determined by $\boldsymbol{x}_{i t}, \boldsymbol{z}_{i t}, a_{i}$ and $\epsilon_{1, i t}$ and therefore conditionally uncorrelated with its lagged value. If this assumption holds, an omission of the lagged dependent variable is justified and does not induce a bias. Second, the strict exogeneity assumption implies the absence of a so-called feedback effect of the error term on future dependent variables. The inclusion of the individual-specific effects, which are allowed to be correlated with explanatory variables, are helpful to absorb most of this correlation. Time-variant shocks directly affecting the current dependent variable and future 
explanatory variables (and not via the dependent variable) should be rare, although this cannot be tested for. Since allowing for a correlation between $a_{i}$ and $\boldsymbol{x}_{i t}$ is indispensable, we focus on the FE and CRE model.

\section{Additional References}

[1] Allison, P. D., Waterman, R. P. (2002). Fixed-effects negative binomial regression models. Sociological Methodology, 32(1), 247-265.

[2] Andersen, E. B. (1970). Asymptotic properties of conditional maximum-likelihood estimators. Journal of the Royal Statistical Society: Series B (Methodological), 32(2), 283-301.

[3] Arntz, M., Dlugosz, S., Wilke, R. A. (2017). The sorting of female careers after first birth: a competing risks analysis of maternity leave duration. Oxford Bulletin of Economics and Statistics, 79(5), 689-716.

[4] Bundesministerium für Familie, Senioren, Frauen und Jugend (2004). Erziehungsgeld, Elternzeit. Das Bundeserziehungsgeldgesetz. Bonn.

[5] Cameron, A. C., Trivedi, P. K. (2010). Microeconometrics using stata (Vol. 2). College Station, TX: Stata press.

[6] Cameron, A. C., Trivedi, P. K. (2013). Regression analysis of count data (Vol. 53). Cambridge university press.

[7] Chamberlain, G. (1980). Analysis of covariance with qualitative data. Review of Economic Studies, 225-238.

[8] Chamberlain, G. (1982). Multivariate regression models for panel data. Journal of Econometrics, 18(1), 5-46.

[9] Fagnani, J. (1994). L'allocation parentale d'éducation en France et en Allemagne. Une prestation, deux logiques. Revue des Politiques Sociales et Familiales, 36(1), 49-52.

[10] Fitzenberger, B., Osikominu, A., Völter, R. (2006). Imputation rules to improve the education variable in the IAB employment subsample. ZEW Discussion Paper, 05-10. 
[11] Hausman, J. A., Hall, B. H., Griliches, Z. (1984). Econometric models for count data with an application to the patents-R\&D relationship. Econometrica, 52, 909-938.

[12] Hoem, J. M., Neyer, G., Andersson, G. (2006). Educational attainment and ultimate fertility among Swedish women born in 1955-59. Demographic Research, 14, 381-404.

[13] Lauer, C., Weber, A. M. (2003). Employment of mothers after childbirth: A FrenchGerman comparison. ZEW Discussion Paper, 03-50.

[14] Melkersson, M., Rooth, D. O. (2000). Modeling female fertility using inflated count data models. Journal of Population Economics, 13(2), 189-203.

[15] Mundlak, Y. (1978). On the pooling of time series and cross section data. Econometrica, $69-85$.

[16] Palmgren, J. (1981). The Fisher information matrix for log linear models arguing conditionally on observed explanatory variable. Biometrika, 68(2), 563-566.

[17] Plantenga, J., Remery, C., Helming, P., Meulders, D., Kanjuo-Mrčela, A. (2005). Reconciliation of work and private life: A comparative review of thirty European countries. Luxembourg: office for official publications of the European Communities.

[18] Wang,W., Famoye, F. (1997). Modeling household fertility decisions with generalized Poisson regression. Journal of Population Economics, 10(3), 273-283.

[19] Wooldridge, J. M. (1999). Distribution-free estimation of some nonlinear panel data models. Journal of Econometrics, 90(1), 77-97.

[20] Wooldridge, J. M. (2010). Econometric analysis of cross section and panel data. MIT press. 


\section{S.I: A Model for the Optimal Number of Children}

The utility $U_{i}$ of female $i$ is characterised by her preferences over consumption, hours of work, schooling and the number of children which are denoted by $(c, h, s, y)$, respectively. Following Becker and Lewis (1973), the optimal number of children maximises the woman's utility function $U_{i}(c, h, s, y)$ subject to the household's budget constraint. To remain focused on relevant channels, we assume a unitary approach of the household, and consider only the utility function of the mother. In contrast to Becker and Lewis (1973), the utility derived from children depends only on their quantity and not on their quality, because expenditure per child ("quality") is assumed to be exogenously determined by social expectations (Duesenberry, 1960; Willis, 1973).

We assume neither a specific functional form for $U_{i}$, nor that $U_{i}$ is monotonically increasing in $y$. This is helpful to explain why some women prefer to stay childless, or have a small number of children. However, in order to reduce the dimension of heterogeneity, we assume that for any $i$ the individual-specific utility function is related to an average utility function $U(c, h, s, y)$ by

$$
U_{i}(c, h, s, y)=U(c, h, s, y)+a_{c i} c+a_{h i} h+a_{s i} s+a_{y i} y+a_{i},
$$

where the heterogeneity components $\left(a_{c i}, a_{h i}, a_{s i}, a_{y i}, a_{i}\right)$ follow some joint distribution. These parameters denote individual preferences for consumption, labour, schooling and children. They are known by the woman but unobserved by the econometrician. Regarding a woman's choice of her optimal number of children, we only have to focus on $a_{y i}$ explicitly. We assume that $U$ is increasing in $y$ and concave.

In order to be consistent with our empirical model, we consider the total number of children instead of conception. However, given the conditionally exogenous level of $y_{i, t-1}$, it is equivalent for the woman to choose either the number of children $y_{i t}$ or conception.

The budget constraint is given by

$$
p_{c} c+p_{y} y=\left[1-t_{1}(y)\right] m_{1}(h, s, y)+m_{2}+t_{2}(y)
$$

with $c, h, s, y \geq 0, p_{c}$ the price of consumption and $p_{y}$ the cost induced by children. Expenditures on consumption and on children appear on the LHS of (17). The income of the 
household on the RHS of (17) consists of non-negative labour market income of the mother $m_{1}$, and of the partner $m_{2}$. The number of children can affect the household income in three possible ways: first, children impose opportunity costs in terms of lost wages, skill depreciation or career impediment. This channel is captured by the function $m_{1}(h, s, y)$. The woman is aware that her labour income is nonincreasing in the number of children and nondecreasing in hours and schooling. Since child-rearing is still mainly a female task, as the take-up rates of the child-rearing benefits in both countries suggest, the opportunity costs are assumed to be entirely borne by the woman while the partner's income $m_{2}$ is exogenous. A mother can opt between withdrawing from the labour market to take care of her children or continuing to work. Empirically, we consider the cases of non-participation, $h=0$, part-time and full-time work. Second, children affect the household income via the income taxation scheme $t_{1}(y)$. This subsidised tax rate $0 \leq t_{1} \leq 1$ is nonincreasing in $y$ and captures the French family tax splitting, the German child tax allowance and earnings-related child-rearing benefits. Third, the government may distribute a lump-sum cash benefit $t_{2}(y)$ which is nondecreasing in $y$ and independent of the income and employment decision of the parents. This corresponds to child cash benefits in both countries and the French basic allowance of the early childhood benefit. All three of these channels can be influenced by the national family policies and may be different in France and Germany.

We assume that the choice of schooling is made earlier in life and is exogenous when deciding about children. For simplification, we treat the discrete variable $y$ as if it was continuous. Then, maximizing the utility function subject to the budget constraint (17) yields the necessary condition for a maximum:

$$
\frac{\partial U}{\partial y}(c, h, s, y)+a_{y i} \leq \lambda\left(p_{y}+t_{1}^{\prime}(y) m_{1}(h, s, y)-\left[1-t_{1}(y)\right] \frac{\partial m_{1}}{\partial y}(h, s, y)-t_{2}^{\prime}(y)\right)
$$

with equality if $y>0$. The term $\lambda \geq 0$ corresponds to the Lagrange multiplier associated to the budget constraint. While the LHS represents the marginal utility of an additional child, the RHS corresponds to the marginal cost. Note that the woman's decision depends upon her marginal utility, and that most unobserved individual heterogeneity enters her decision rule additively. Sufficient conditions ensuring the existence of a nonempty set of solutions to this inequality are not very restrictive. The unobserved individual preference for children $a_{y i}$ allows women with the same level for all explanatory variables to have different numbers 
of children. The first order condition (18) for the optimal number of children illustrates the three channels for a family policy to reduce the marginal price of children. Ceteris paribus, the number of children of woman $i$ tends to be high when the marginal opportunity costs $\partial m_{1} / \partial y$ are low, when both the tax reduction $t_{1}(y)$ and the marginal tax reduction $t_{1}^{\prime}(y) \leq 0$ are high (due to $\partial m_{1} / \partial y \leq 0$ ), and when the marginal lump sum benefit $t_{2}^{\prime}(y)$ is high. In the following, we will further highlight the impact of relevant variables in the first order condition (18).

If French mothers adjust their working behaviour following childbirth less than German mothers due to better coordinated childcare facilities, $\partial m_{1} / \partial y$ is smaller in absolute value in France than in Germany and total fertility is likely to be higher in France compared to Germany. In addition, opportunity costs are likely to have an impact on the timing of births: due to difficulties in reconciling family and working life, German women with family and career aspirations can either have children early and start a career when their children are old enough to attend kindergarten (three years), or postpone their first childbirth to a point in time at which career goals have already been achieved. Francesconi (2002) proxies career advancement by a wage increase and finds empirical evidence for the US that an upward wage slope affects fertility negatively. Additionally, German women often exploit time out of work for conceiving several children sequentially in order to reduce the opportunity costs (Arntz et al., 2017).

The optimality condition (18) also highlights the ambiguous impact of a woman's income on her fertility decision: on the one hand, the decrease in the marginal cost of children through lower income taxes (due to $t_{1}^{\prime}(y) \leq 0$ ) is more pronounced the higher the income. On the other hand the opportunity cost term $\partial m_{1} / \partial y \leq 0$ may well compensate the first effect. The total increase in the cost of a child with female wages therefore depends on the functional form of $t_{1}(y)$ and may be less important in France than in Germany, due to a more pronounced wage decrease in Germany and higher family tax benefits in France. A reduction in the cost of children or even a positive income effect may especially be the case for high income French households, which benefit from relatively generous aggregated child benefits as described in Section 2. However, neither the wage of the partner, nor the nonlabour family income is recorded in our data base, ruling out the differentiation between opportunity cost and income effect, as well as the differentiation between the different taxation parameters. 
Regarding schooling, two opposite effects occur in equation (18): on the one hand, longer schooling increases $m_{1}$ and hence absolute opportunity costs of children. On the other hand, while deciding over the length of schooling, children and schooling may act as substitutes: women with a strong preference for children (positive $a_{y i}$ ) may self-select themselves in reducing the length of schooling (Adda et al., 2017). However, here we consider this choice as predetermined.

One main source for the randomness of $y$ is the individual-specific unobserved heterogeneity term $a_{y i}$ which justifies the inclusion of fixed or correlated random effects $a_{i}$ in our empirical specification. We also see that macroeconomic variables which are similar for all women in one country and vary over time do play an important role. We therefore introduce time dummies to control for $p_{y}, t_{1}, t_{1}^{\prime}, t_{2}^{\prime}$. We include a comprehensive set of explanatory variables $\boldsymbol{x}_{i t}$ which capture schooling, income and hours of work. Under some mild regularity conditions, expression (18) can be used to express the number of children as a function of $m_{1}, s$, unobserved heterogeneity and other explanatory variables and yields our specification for the conditional probability $\operatorname{Pr}\left[y=y_{i t} \mid \boldsymbol{x}_{i t}, a_{i}\right]$ to have $y_{i t}$ children.

\section{S.II Additional Empirical Results}

Additional empirical results are presented. We extend the above specifications which considered only explanatory variables available both for France and Germany, by including country-specific regressors (available only for France or only for Germany). For Germany, additional observations are now included which had to be dropped because of the tight selection criteria in the French data. This permits to assess the robustness of the results in Section 6 and to obtain estimates for the marginal effects for additional variables. The results are presented in Tables S.1 and S.2. 
Table S.1: Country-specific Results for Germany

\begin{tabular}{|c|c|c|c|c|c|c|c|}
\hline & \multicolumn{2}{|c|}{ Linear } & \multicolumn{5}{|c|}{ Poisson } \\
\hline & OLS & $\mathrm{FE}$ & Pooled & $\mathrm{FE}$ & $\mathrm{RE}$ & $\mathrm{CRE}$ & CRE-ME \\
\hline \multicolumn{8}{|l|}{ Age } \\
\hline \multirow[t]{2}{*}{$23-27$} & $0.16^{* * *}$ & $0.07^{* * *}$ & $1.02 * * *$ & $0.83^{* * *}$ & $0.89^{* * *}$ & $0.84^{* * *}$ & $0.43^{* * *}$ \\
\hline & $(0.00)$ & $(0.00)$ & $(0.01)$ & $(0.01)$ & $(0.01)$ & $(0.01)$ & $(0.01)$ \\
\hline \multirow{2}{*}{$28-32$} & $0.39^{* * *}$ & $0.19^{* * *}$ & $1.40 * * *$ & $1.12^{* * *}$ & $1.19^{* * *}$ & $1.12^{* * *}$ & $0.81^{* * *}$ \\
\hline & $(0.01)$ & $(0.00)$ & $(0.01)$ & $(0.02)$ & $(0.01)$ & $(0.01)$ & $(0.01)$ \\
\hline \multirow[t]{2}{*}{$33-37$} & $0.60^{* * *}$ & $0.26^{* * *}$ & $1.64^{* * *}$ & $1.20^{* * *}$ & $1.29^{* * *}$ & $1.20^{* * *}$ & $1.00^{* * *}$ \\
\hline & $(0.01)$ & $(0.00)$ & $(0.01)$ & $(0.02)$ & $(0.01)$ & $(0.01)$ & $(0.01)$ \\
\hline \multirow[t]{2}{*}{$38-45$} & $0.78^{* * *}$ & $0.23^{* * *}$ & $1.81^{* * *}$ & $1.15^{* * *}$ & $1.26^{* * *}$ & $1.15^{* * *}$ & $1.02^{* * *}$ \\
\hline & $(0.01)$ & $(0.01)$ & $(0.01)$ & $(0.02)$ & $(0.01)$ & $(0.01)$ & $(0.01)$ \\
\hline \multicolumn{8}{|l|}{ Education } \\
\hline \multirow[t]{2}{*}{$\mathrm{VT}$} & $-0.11^{* * *}$ & & $-0.96^{* * *}$ & & $-0.72^{* * *}$ & $-0.84^{* * *}$ & $-0.25^{* * *}$ \\
\hline & $(0.00)$ & & $(0.02)$ & & $(0.02)$ & $(0.02)$ & $(0.01)$ \\
\hline \multirow[t]{2}{*}{$\mathrm{TE}$} & $-0.10 * * *$ & & $-2.83^{* * *}$ & & $-2.54^{* * *}$ & $-2.36^{* * *}$ & $-0.47 * * *$ \\
\hline & $(0.00)$ & & $(0.07)$ & & $(0.12)$ & $(0.11)$ & $(0.01)$ \\
\hline \multicolumn{8}{|c|}{ Education $\times$ Age } \\
\hline \multirow[t]{2}{*}{$\mathrm{VT} \times 23-27$} & $-0.06^{* * *}$ & $-0.02^{* * *}$ & $0.45^{* * *}$ & $0.36^{* * *}$ & $0.37^{* * *}$ & $0.38^{* * *}$ & \\
\hline & $(0.00)$ & $(0.00)$ & $(0.02)$ & $(0.02)$ & $(0.02)$ & $(0.02)$ & \\
\hline \multirow{2}{*}{$\mathrm{TE} \times 23-27$} & $-0.14^{* * *}$ & $-0.12^{* * *}$ & $1.03^{* * *}$ & $0.84^{* * *}$ & $0.90^{* * *}$ & $0.86^{* * *}$ & \\
\hline & $(0.00)$ & $(0.00)$ & $(0.07)$ & $(0.10)$ & $(0.11)$ & $(0.11)$ & \\
\hline \multirow[t]{2}{*}{$\mathrm{VT} \times 28-32$} & $-0.06^{* * *}$ & 0.01 & $0.68^{* * *}$ & $0.54^{* * *}$ & $0.56^{* * *}$ & $0.57^{* * *}$ & \\
\hline & $(0.01)$ & $(0.01)$ & $(0.02)$ & $(0.02)$ & $(0.02)$ & $(0.02)$ & \\
\hline \multirow[t]{2}{*}{$\mathrm{TE} \times 28-32$} & $-0.22^{* * *}$ & $-0.16^{* * *}$ & $2.00^{* * *}$ & $1.53^{* * *}$ & $1.65^{* * *}$ & $1.59^{* * *}$ & \\
\hline & $(0.01)$ & $(0.01)$ & $(0.07)$ & $(0.11)$ & $(0.11)$ & $(0.11)$ & \\
\hline \multirow[t]{2}{*}{$\mathrm{VT} \times 33-37$} & $0.02^{* *}$ & $0.06^{* * *}$ & $0.80^{* * *}$ & $0.58^{* * *}$ & $0.61^{* * *}$ & $0.62^{* * *}$ & \\
\hline & $(0.01)$ & $(0.01)$ & $(0.02)$ & $(0.02)$ & $(0.02)$ & $(0.02)$ & \\
\hline \multirow[t]{2}{*}{$\mathrm{TE} \times 33-37$} & $-0.20 * * *$ & $-0.09 * * *$ & $2.43^{* * *}$ & $1.80^{* * *}$ & $1.97^{* * *}$ & $1.89^{* * *}$ & \\
\hline & $(0.01)$ & $(0.01)$ & $(0.07)$ & $(0.11)$ & $(0.11)$ & $(0.11)$ & \\
\hline \multirow[t]{2}{*}{$\mathrm{VT} \times 38-45$} & $0.09^{* * *}$ & $0.08^{* * *}$ & $0.88^{* * *}$ & $0.59^{* * *}$ & $0.63^{* * *}$ & $0.64^{* * *}$ & \\
\hline & $(0.01)$ & $(0.01)$ & $(0.02)$ & $(0.02)$ & $(0.02)$ & $(0.02)$ & \\
\hline \multirow[t]{2}{*}{$\mathrm{TE} \times 38-45$} & $-0.11^{* * *}$ & $-0.03^{* *}$ & $2.64^{* * *}$ & $1.86^{* * *}$ & $2.05^{* * *}$ & $1.97^{* * *}$ & \\
\hline & $(0.01)$ & $(0.01)$ & $(0.07)$ & $(0.11)$ & $(0.12)$ & $(0.11)$ & \\
\hline \multicolumn{8}{|l|}{ Employment } \\
\hline \multirow[t]{2}{*}{ Part-time } & $0.31^{* * *}$ & $0.04^{* * *}$ & $0.70^{* * *}$ & $0.06^{* * *}$ & $0.13^{* * *}$ & $0.11^{* * *}$ & $0.10^{* * *}$ \\
\hline & $(0.00)$ & $(0.00)$ & $(0.00)$ & $(0.00)$ & $(0.00)$ & $(0.00)$ & $(0.00)$ \\
\hline \multirow[t]{2}{*}{ Full-time } & $0.07^{* * *}$ & $-0.03^{* * *}$ & $0.39^{* * *}$ & $-0.03^{* * *}$ & $0.01^{*}$ & -0.01 & $-0.02^{* * *}$ \\
\hline & $(0.00)$ & $(0.00)$ & $(0.00)$ & $(0.00)$ & $(0.00)$ & $(0.00)$ & $(0.00)$ \\
\hline Wage & & & & & & & \\
\hline
\end{tabular}

Continued on next page 


\begin{tabular}{|c|c|c|c|c|c|c|c|}
\hline & \multicolumn{2}{|c|}{ Linear } & \multicolumn{5}{|c|}{ Poisson } \\
\hline & OLS & $\mathrm{FE}$ & Pooled & $\mathrm{FE}$ & $\mathrm{RE}$ & $\mathrm{CRE}$ & CRE-ME \\
\hline $25-49 \%$ & $\begin{array}{l}-0.03^{* * *} \\
(0.00)\end{array}$ & $\begin{array}{l}-0.05^{* * *} \\
(0.00)\end{array}$ & $\begin{array}{l}-0.10^{* * *} \\
(0.00)\end{array}$ & $\begin{array}{l}-0.04^{* * *} \\
(0.00)\end{array}$ & $\begin{array}{l}-0.04^{* * *} \\
(0.00)\end{array}$ & $\begin{array}{l}-0.04^{* * *} \\
(0.00)\end{array}$ & $\begin{array}{l}-0.05^{* * *} \\
(0.00)\end{array}$ \\
\hline $50-74 \%$ & $\begin{array}{l}-0.13^{* * *} \\
(0.00)\end{array}$ & $\begin{array}{l}-0.09^{* * *} \\
(0.00)\end{array}$ & $\begin{array}{l}-0.27^{* * *} \\
(0.00)\end{array}$ & $\begin{array}{l}-0.12^{* * *} \\
(0.00)\end{array}$ & $\begin{array}{l}-0.13^{* * *} \\
(0.00)\end{array}$ & $\begin{array}{l}-0.12^{* * *} \\
(0.00)\end{array}$ & $\begin{array}{l}-0.13^{* * *} \\
(0.00)\end{array}$ \\
\hline $75-89 \%$ & $\begin{array}{l}-0.22^{* * *} \\
(0.01)\end{array}$ & $\begin{array}{l}-0.14^{* * *} \\
(0.00)\end{array}$ & $\begin{array}{l}-0.42^{* * *} \\
(0.00)\end{array}$ & $\begin{array}{l}-0.18^{* * *} \\
(0.00)\end{array}$ & $\begin{array}{l}-0.21^{* * *} \\
(0.00)\end{array}$ & $\begin{array}{l}-0.19^{* * *} \\
(0.00)\end{array}$ & $\begin{array}{l}-0.19^{* * *} \\
(0.00)\end{array}$ \\
\hline $90-94 \%$ & $\begin{array}{l}-0.30 * * * \\
(0.01)\end{array}$ & $\begin{array}{l}-0.17^{* * *} \\
(0.00)\end{array}$ & $\begin{array}{l}-0.55^{* * *} \\
(0.01)\end{array}$ & $\begin{array}{l}-0.20^{* * *} \\
(0.00)\end{array}$ & $\begin{array}{l}-0.26^{* * *} \\
(0.01)\end{array}$ & $\begin{array}{l}-0.21^{* * *} \\
(0.01)\end{array}$ & $\begin{array}{l}-0.22^{* * *} \\
(0.00)\end{array}$ \\
\hline $95-98 \%$ & $\begin{array}{l}-0.38^{* * *} \\
(0.01)\end{array}$ & $\begin{array}{l}-0.19^{* * *} \\
(0.00)\end{array}$ & $\begin{array}{l}-0.81^{* * *} \\
(0.01)\end{array}$ & $\begin{array}{l}-0.22^{* * *} \\
(0.01)\end{array}$ & $\begin{array}{l}-0.31^{* * *} \\
(0.01)\end{array}$ & $\begin{array}{l}-0.26^{* * *} \\
(0.01)\end{array}$ & $\begin{array}{l}-0.26^{* * *} \\
(0.01)\end{array}$ \\
\hline $99-100 \%$ & $\begin{array}{l}-0.44^{* * *} \\
(0.01)\end{array}$ & $\begin{array}{l}-0.22^{* * *} \\
(0.01)\end{array}$ & $\begin{array}{l}-1.13^{* * *} \\
(0.02)\end{array}$ & $\begin{array}{l}-0.07^{* * *} \\
(0.02)\end{array}$ & $\begin{array}{l}-0.23^{* * *} \\
(0.02)\end{array}$ & $\begin{array}{l}-0.16^{* * *} \\
(0.02)\end{array}$ & $\begin{array}{l}-0.19^{* * *} \\
(0.01)\end{array}$ \\
\hline \multicolumn{8}{|c|}{ Wage Increase } \\
\hline$>0$ & $\begin{array}{l}0.06^{* * *} \\
(0.00)\end{array}$ & $\begin{array}{l}0.01^{* * *} \\
(0.00)\end{array}$ & $\begin{array}{l}0.03^{* * *} \\
(0.00)\end{array}$ & $\begin{array}{l}-0.01^{* * *} \\
(0.00)\end{array}$ & $\begin{array}{l}-0.01^{* * *} \\
(0.00)\end{array}$ & $\begin{array}{l}-0.01^{* * *} \\
(0.00)\end{array}$ & $\begin{array}{l}-0.04^{* * *} \\
(0.00)\end{array}$ \\
\hline$>$ median & $\begin{array}{l}0.10^{* * *} \\
(0.00)\end{array}$ & $\begin{array}{l}0.04^{* * *} \\
(0.00)\end{array}$ & $\begin{array}{l}0.09^{* * * *} \\
(0.00)\end{array}$ & $\begin{array}{l}0.04^{* * *} \\
(0.00\end{array}$ & $\begin{array}{l}0.03^{* * *} \\
(0.00)\end{array}$ & $\begin{array}{l}0.04^{* * *} \\
(0.00)\end{array}$ & $\begin{array}{l}-0.03^{* * *} \\
(0.00)\end{array}$ \\
\hline \multicolumn{8}{|c|}{ Tenure in months } \\
\hline $6-11$ & $\begin{array}{l}0.02^{* * *} \\
(0.00)\end{array}$ & $\begin{array}{l}0.01^{* * *} \\
(0.00)\end{array}$ & $\begin{array}{l}0.01^{* * * *} \\
(0.00)\end{array}$ & $\begin{array}{l}-0.01^{* * *} \\
(0.00)\end{array}$ & $\begin{array}{l}-0.01^{* * *} \\
(0.00)\end{array}$ & $\begin{array}{l}-0.01^{* * *} \\
(0.00)\end{array}$ & $\begin{array}{l}-0.01^{* * *} \\
(0.00)\end{array}$ \\
\hline $12-23$ & $\begin{array}{l}0.09^{* * *} \\
(0.00)\end{array}$ & $\begin{array}{l}0.02^{* * *} \\
(0.00)\end{array}$ & $\begin{array}{l}0.15^{* * *} \\
(0.00)\end{array}$ & $\begin{array}{l}0.04^{* * *} \\
(0.00)\end{array}$ & $\begin{array}{l}0.05^{* * *} \\
(0.00)\end{array}$ & $\begin{array}{l}0.04^{* * *} \\
(0.00)\end{array}$ & $\begin{array}{l}0.04^{* * *} \\
(0.00)\end{array}$ \\
\hline $24-35$ & $\begin{array}{l}0.09 * * * \\
(0.00)\end{array}$ & $\begin{array}{l}0.02^{* * *} \\
(0.00)\end{array}$ & $\begin{array}{l}0.17^{* * *} \\
(0.00)\end{array}$ & $\begin{array}{l}0.04^{* * *} \\
(0.00)\end{array}$ & $\begin{array}{l}0.05^{* * *} \\
(0.00)\end{array}$ & $\begin{array}{l}0.05^{* * *} \\
(0.00)\end{array}$ & $\begin{array}{l}0.04^{* * *} \\
(0.00)\end{array}$ \\
\hline$\geq 36$ & $\begin{array}{l}0.01^{* *} \\
(0.00)\end{array}$ & $\begin{array}{l}0.00^{* * *} \\
(0.00)\end{array}$ & $\begin{array}{l}0.05^{* * *} \\
(0.00)\end{array}$ & $\begin{array}{l}0.03^{* * *} \\
(0.00)\end{array}$ & $\begin{array}{l}0.03^{* * *} \\
(0.00)\end{array}$ & $\begin{array}{l}0.04^{* * *} \\
(0.00)\end{array}$ & $\begin{array}{l}0.03^{* * *} \\
(0.00)\end{array}$ \\
\hline \multicolumn{8}{|c|}{ Occupational Choice } \\
\hline Teacher & $\begin{array}{l}0.08^{* * *} \\
(0.01)\end{array}$ & $\begin{array}{l}0.00 \\
(0.00)\end{array}$ & $\begin{array}{l}0.18^{* * *} \\
(0.01)\end{array}$ & $\begin{array}{l}0.03^{* * *} \\
(0.01)\end{array}$ & $\begin{array}{l}0.04^{* * *} \\
(0.01)\end{array}$ & $\begin{array}{l}0.05^{* * *} \\
(0.01)\end{array}$ & $\begin{array}{l}0.05^{* * *} \\
(0.01)\end{array}$ \\
\hline Cohort & & & & & & & \\
\hline $1959-68$ & $\begin{array}{l}-0.16^{* * *} \\
(0.01)\end{array}$ & & $\begin{array}{l}-0.16^{* * *} \\
(0.00)\end{array}$ & & $\begin{array}{l}-0.46^{* * *} \\
(0.01)\end{array}$ & $\begin{array}{l}-0.55^{* * *} \\
(0.01)\end{array}$ & $\begin{array}{l}-0.54^{* * *} \\
(0.02)\end{array}$ \\
\hline 1969-78 & $\begin{array}{l}-0.21^{* * *} \\
(0.01)\end{array}$ & & $\begin{array}{l}-0.31^{* * *} \\
(0.01)\end{array}$ & & $\begin{array}{l}-1.04^{* * *} \\
(0.01)\end{array}$ & $\begin{array}{l}-0.31^{* * *} \\
(0.02)\end{array}$ & $\begin{array}{l}-0.42^{* * *} \\
(0.03)\end{array}$ \\
\hline 1979-89 & $\begin{array}{l}-0.26^{* * *} \\
(0.01)\end{array}$ & & $\begin{array}{l}-1.24^{* * *} \\
(0.01)\end{array}$ & & $\begin{array}{l}-2.36^{* * *} \\
(0.02)\end{array}$ & $\begin{array}{l}-0.58^{* * *} \\
(0.04)\end{array}$ & $\begin{array}{l}-0.62^{* * *} \\
(0.04)\end{array}$ \\
\hline Year & & & & & & & \\
\hline $1997-1999$ & $\begin{array}{l}-0.00 \\
(0.00)\end{array}$ & $\begin{array}{l}0.07^{* * *} \\
(0.00)\end{array}$ & $\begin{array}{l}-0.01^{*} \\
(0.00)\end{array}$ & $\begin{array}{l}0.06^{* * *} \\
(0.00)\end{array}$ & $\begin{array}{l}0.05^{* * *} \\
(0.00)\end{array}$ & $\begin{array}{l}0.06^{* * *} \\
(0.00)\end{array}$ & $\begin{array}{l}0.05^{* * *} \\
(0.00)\end{array}$ \\
\hline
\end{tabular}

Continued on next page 


\begin{tabular}{|c|c|c|c|c|c|c|c|}
\hline & \multicolumn{2}{|c|}{ Linear } & \multicolumn{5}{|c|}{ Poisson } \\
\hline & OLS & $\mathrm{FE}$ & Pooled & $\mathrm{FE}$ & $\mathrm{RE}$ & $\mathrm{CRE}$ & CRE-ME \\
\hline \multirow[t]{2}{*}{$2000-2002$} & $0.01^{* * *}$ & $0.14^{* * *}$ & $0.03^{* * *}$ & $0.18^{* * *}$ & $0.16^{* * *}$ & $0.17^{* * *}$ & $0.16^{* * *}$ \\
\hline & $(0.00)$ & $(0.00)$ & $(0.00)$ & $(0.00)$ & $(0.00)$ & $(0.00)$ & $(0.00)$ \\
\hline \multirow[t]{2}{*}{$2003-2005$} & 0.01 & $0.19^{* * *}$ & $0.05^{* * *}$ & $0.28^{* * *}$ & $0.26^{* * *}$ & $0.27^{* * *}$ & $0.27^{* * *}$ \\
\hline & $(0.00)$ & $(0.00)$ & $(0.00)$ & $(0.00)$ & $(0.00)$ & $(0.00)$ & $(0.00)$ \\
\hline \multirow[t]{2}{*}{$2006-2007$} & $-0.01^{*}$ & $0.24^{* * *}$ & $0.07^{* * *}$ & $0.39^{* * *}$ & $0.36^{* * *}$ & $0.38^{* * *}$ & $0.40^{* * *}$ \\
\hline & $(0.00)$ & $(0.00)$ & $(0.00)$ & $(0.00)$ & $(0.00)$ & $(0.00)$ & $(0.00)$ \\
\hline \multicolumn{8}{|c|}{ Regressors specific for Germany } \\
\hline \multicolumn{8}{|c|}{ Past Employment } \\
\hline \multirow[t]{2}{*}{ Unemployed } & $0.04^{* * *}$ & $-0.01^{* * *}$ & $0.11^{* * *}$ & $-0.00^{*}$ & $0.02^{* * *}$ & $0.01^{* * *}$ & $0.02^{* * *}$ \\
\hline & $(0.00)$ & $(0.00)$ & $(0.00)$ & $(0.00)$ & $(0.00)$ & $(0.00)$ & $(0.00)$ \\
\hline \multirow[t]{2}{*}{ Inactive } & $0.94^{* * *}$ & $0.23^{* * *}$ & $0.74^{* * *}$ & $0.21^{* * *}$ & $0.25^{* * *}$ & $0.21^{* * *}$ & $0.52^{* * *}$ \\
\hline & $(0.00)$ & $(0.00)$ & $(0.00)$ & $(0.00)$ & $(0.00)$ & $(0.00)$ & $(0.01)$ \\
\hline \multirow[t]{2}{*}{ Unobserved } & $-0.24^{* * *}$ & $-0.03^{* * *}$ & $-0.43^{* * *}$ & -0.00 & $-0.05^{* * *}$ & $0.00^{* * *}$ & $-0.02^{* * *}$ \\
\hline & $(0.00)$ & $(0.00)$ & $(0.00)$ & $(0.00)$ & $(0.00)$ & $(0.00)$ & $(0.00)$ \\
\hline \multicolumn{8}{|l|}{ Nationality } \\
\hline \multirow[t]{2}{*}{ Foreigner } & $-0.10^{* * *}$ & & $-0.18^{* * *}$ & & $-0.27^{* * *}$ & $-0.17^{* * *}$ & $-0.16^{* * *}$ \\
\hline & $(0.00)$ & & $(0.00)$ & & $(0.01)$ & $(0.01)$ & $(0.01)$ \\
\hline \multicolumn{8}{|l|}{ Former GDR } \\
\hline \multirow[t]{2}{*}{ GDR } & $0.45^{* * *}$ & & $0.21^{* * *}$ & & $0.34^{* * *}$ & $0.34^{* * *}$ & $0.46^{* * *}$ \\
\hline & $(0.01)$ & & $(0.00)$ & & $(0.01)$ & $(0.01)$ & $(0.01)$ \\
\hline \multicolumn{8}{|c|}{ Former GDR $\times$ Cohort } \\
\hline \multirow[t]{2}{*}{ GDR $\times 1959-68$} & -0.02 & & $0.09^{* * *}$ & & $0.17^{* * *}$ & $0.22^{* * *}$ & \\
\hline & $(0.02)$ & & $(0.00)$ & & $(0.01)$ & $(0.02)$ & \\
\hline \multirow[t]{2}{*}{ GDR $\times 1969-78$} & $-0.37^{* * *}$ & & $0.03^{* * *}$ & & $0.11^{* * *}$ & $-0.24^{* * *}$ & \\
\hline & $(0.02)$ & & $(0.01)$ & & $(0.02)$ & $(0.02)$ & \\
\hline \multirow[t]{2}{*}{ GDR $\times 1979-89$} & $-0.51^{* * *}$ & & -0.01 & & -0.02 & -0.07 & \\
\hline & $(0.01)$ & & $(0.02)$ & & $(0.04)$ & $(0.04)$ & \\
\hline \multicolumn{8}{|l|}{ Federal States } \\
\hline \multirow[t]{2}{*}{ SH \& MV } & $-0.24^{* * *}$ & 0.01 & $-0.54^{* * *}$ & $-0.06^{* * *}$ & $-0.13^{* * *}$ & $-0.10^{* * *}$ & $-0.10^{* * *}$ \\
\hline & $(0.01)$ & $(0.00)$ & $(0.01)$ & $(0.01)$ & $(0.01)$ & $(0.01)$ & $(0.00)$ \\
\hline \multirow[t]{2}{*}{ LS \& B } & $-0.25^{* * *}$ & -0.00 & $-0.60^{* * *}$ & $-0.07 * * *$ & $-0.13^{* * *}$ & $-0.10^{* * *}$ & $-0.10^{* * *}$ \\
\hline & $(0.01)$ & $(0.00)$ & $(0.00)$ & $(0.00)$ & $(0.00)$ & $(0.00)$ & $(0.00)$ \\
\hline \multirow[t]{2}{*}{ NRW } & $-0.29 * * *$ & $-0.01^{* * *}$ & $-0.68^{* * *}$ & $-0.08 * * *$ & $-0.16^{* * *}$ & $-0.13^{* * *}$ & $-0.12^{* * *}$ \\
\hline & $(0.00)$ & $(0.00)$ & $(0.00)$ & $(0.00)$ & $(0.00)$ & $(0.00)$ & $(0.00)$ \\
\hline \multirow[t]{2}{*}{ Hesse } & $-0.31^{* * *}$ & -0.00 & $-0.73^{* * *}$ & $-0.08^{* * *}$ & $-0.18^{* * *}$ & $-0.15^{* * *}$ & $-0.14^{* * *}$ \\
\hline & $(0.01)$ & $(0.00)$ & $(0.01)$ & $(0.00)$ & $(0.01)$ & $(0.01)$ & $(0.00)$ \\
\hline \multirow[t]{2}{*}{$\mathrm{RP} \& \mathrm{~S}$} & $-0.34^{* * *}$ & 0.00 & $-0.73^{* * *}$ & $-0.08^{* * *}$ & $-0.17 * * *$ & $-0.13^{* * *}$ & $-0.13^{* * *}$ \\
\hline & $(0.01)$ & $(0.00)$ & $(0.01)$ & $(0.00)$ & $(0.01)$ & $(0.01)$ & $(0.01)$ \\
\hline BW & $-0.26^{* * *}$ & 0.00 & $-0.64^{* * *}$ & $-0.08^{* * *}$ & $-0.15^{* * *}$ & $-0.12^{* * *}$ & $-0.11^{* * *}$ \\
\hline
\end{tabular}

Continued on next page 


\begin{tabular}{|c|c|c|c|c|c|c|c|}
\hline & \multicolumn{2}{|c|}{ Linear } & \multicolumn{5}{|c|}{ Poisson } \\
\hline & OLS & $\mathrm{FE}$ & Pooled & $\mathrm{FE}$ & $\mathrm{RE}$ & $\mathrm{CRE}$ & CRE-ME \\
\hline & $(0.01)$ & $(0.00)$ & $(0.00)$ & $(0.00)$ & $(0.00)$ & $(0.00)$ & $(0.00)$ \\
\hline Bavaria & $\begin{array}{l}-0.26^{* * *} \\
(0.00)\end{array}$ & $\begin{array}{l}-0.01^{* *} \\
(0.00)\end{array}$ & $\begin{array}{l}-0.62^{* * *} \\
(0.00)\end{array}$ & $\begin{array}{l}-0.09^{* * *} \\
(0.00)\end{array}$ & $\begin{array}{l}-0.15^{* * *} \\
(0.00)\end{array}$ & $\begin{array}{l}-0.12^{* * *} \\
(0.00)\end{array}$ & $\begin{array}{l}-0.12^{* * *} \\
(0.00)\end{array}$ \\
\hline B \& H & $\begin{array}{l}-0.33^{* * *} \\
(0.01)\end{array}$ & $\begin{array}{l}-0.02^{* * *} \\
(0.00)\end{array}$ & $\begin{array}{l}-0.74^{* * *} \\
(0.01)\end{array}$ & $\begin{array}{l}-0.06^{* * *} \\
(0.01)\end{array}$ & $\begin{array}{l}-0.16^{* * *} \\
(0.00)\end{array}$ & $\begin{array}{l}-0.13^{* * *} \\
(0.01)\end{array}$ & $\begin{array}{l}-0.13^{\text {*** }} \\
(0.01)\end{array}$ \\
\hline S \& B & $\begin{array}{l}-0.21^{* * *} \\
(0.01)\end{array}$ & $\begin{array}{l}0.00 \\
(0.00)\end{array}$ & $\begin{array}{l}-0.46^{* * *} \\
(0.00)\end{array}$ & $\begin{array}{l}-0.06^{* * *} \\
(0.00)\end{array}$ & $\begin{array}{l}-0.10^{* * *} \\
(0.00)\end{array}$ & $\begin{array}{l}-0.07^{* * *} \\
(0.00)\end{array}$ & $\begin{array}{l}-0.08^{* * *} \\
(0.00)\end{array}$ \\
\hline SA \& T & $\begin{array}{l}-0.21^{* * *} \\
(0.01)\end{array}$ & $\begin{array}{l}0.00 \\
(0.00) \\
\end{array}$ & $\begin{array}{l}-0.46^{* * *} \\
(0.00) \\
\end{array}$ & $\begin{array}{l}-0.07^{* * *} \\
(0.00)\end{array}$ & $\begin{array}{l}-0.10^{* * *} \\
(0.00)\end{array}$ & $\begin{array}{l}-0.08^{* * *} \\
(0.00)\end{array}$ & $\begin{array}{l}-0.08^{* * *} \\
(0.00)\end{array}$ \\
\hline \multicolumn{8}{|c|}{ Averages of time-varying covariates } \\
\hline$\overline{A g e_{i}}$ & & & & & & $\begin{array}{l}0.54^{* * *} \\
(0.01)\end{array}$ & \\
\hline$\overline{\text { Wage }_{i}}$ & & & & & & $\begin{array}{l}-0.12^{* * *} \\
(0.01)\end{array}$ & \\
\hline$\overline{E m p l_{i}}$ & & & & & & $\begin{array}{l}-0.11^{* * *} \\
(0.01)\end{array}$ & \\
\hline$\overline{\Delta W a g e_{i}}$ & & & & & & $\begin{array}{l}-0.53^{* * *} \\
(0.02)\end{array}$ & \\
\hline$\overline{\text { Tenure }_{i}}$ & & & & & & $\begin{array}{l}-0.02^{* * *} \\
(0.01)\end{array}$ & \\
\hline$\overline{\text { PastUnempl }_{i}}$ & & & & & & $\begin{array}{l}0.12^{* * *} \\
(0.02)\end{array}$ & \\
\hline$\overline{\text { PastInact }_{i}}$ & & & & & & $\begin{array}{l}3.03^{* * *} \\
(0.02)\end{array}$ & \\
\hline$\overline{\text { PastUnobs }}$ & & & & & & $\begin{array}{l}-0.34^{* * *} \\
(0.02)\end{array}$ & \\
\hline $1 / \mathrm{A}$ & & & & & $\begin{array}{l}3.22^{(* * *)} \\
(0.02)\end{array}$ & $\begin{array}{l}2.41^{(* * *)} \\
(0.01)\end{array}$ & \\
\hline Constant & $\begin{array}{l}0.57^{* * *} \\
(0.01)\end{array}$ & $\begin{array}{l}0.31^{* * *} \\
(0.03)\end{array}$ & $\begin{array}{l}-1.38^{* * *} \\
(0.01)\end{array}$ & & $\begin{array}{l}-0.88^{* * *} \\
(0.02)\end{array}$ & $\begin{array}{l}-2.16^{* * *} \\
(0.04)\end{array}$ & \\
\hline Observations & $2,212,027$ & $2,2120,27$ & $2,212,027$ & $1,0101,77$ & $2,212,027$ & $2,212,027$ & \\
\hline $\begin{array}{l}\mathrm{RSS} \text { in } 1,000 \\
\mathrm{LL} \text { in } 1,000\end{array}$ & 1205 & 132 & $-1,832$ & -877 & $-1,359$ & $-1,343$ & \\
\hline
\end{tabular}

Notes: ${ }^{*} p<0.05,{ }^{* *} p<0.01,{ }^{* * *} p<0.001$. Standard errors based on 100 bootstrap replications (this value was chosen due to very long computing times). Controlling for twins and multiples. SH \& MV = Schleswig-Holstein \& Mecklenburg-Western Pomerania, LS \& B = Lower Saxony \& Bremen, NRW = North Rhine-Westphalia, RP \& S = Rhineland-Palatinate \& Saarland, BW = Baden-Wuerttemberg, B \& H = Berlin \& Hamburg, S \& B = Saxony \& Brandenburg, T \& SA = Thuringia \& Saxony-Anhalt. ${ }^{(* *)}$ LR test of $\mathrm{H}_{0}: 1 / \mathrm{A}=0$ is rejected at a significance level $<0.001$. 
Table S.2: Country-specific Results for France

\begin{tabular}{|c|c|c|c|c|c|c|c|}
\hline & \multicolumn{2}{|c|}{ Linear } & \multicolumn{5}{|c|}{ Poisson } \\
\hline & OLS & $\mathrm{FE}$ & Pooled & $\mathrm{FE}$ & $\mathrm{RE}$ & $\mathrm{CRE}$ & CRE-ME \\
\hline \multicolumn{8}{|l|}{ Age } \\
\hline $23-27$ & $\begin{array}{l}0.31^{* * * *} \\
(0.01)\end{array}$ & $\begin{array}{l}0.20^{* * * *} \\
(0.01)\end{array}$ & $\begin{array}{l}1.63^{* * *} \\
(0.03)\end{array}$ & $\begin{array}{l}1.49^{* * *} \\
(0.03)\end{array}$ & $\begin{array}{l}1.52^{* * *} \\
(0.04)\end{array}$ & $\begin{array}{l}1.47^{* * *} \\
(0.04)\end{array}$ & $\begin{array}{l}0.47^{* * *} \\
(0.01)\end{array}$ \\
\hline $28-32$ & $\begin{array}{l}0.81^{* * *} \\
(0.01)\end{array}$ & $\begin{array}{l}0.60^{* * *} \\
(0.01)\end{array}$ & $\begin{array}{l}2.30^{* * *} \\
(0.02)\end{array}$ & $\begin{array}{l}2.09^{* * *} \\
(0.04)\end{array}$ & $\begin{array}{l}2.12^{* * *} \\
(0.04)\end{array}$ & $\begin{array}{l}2.05^{* * *} \\
(0.04)\end{array}$ & $\begin{array}{l}1.05^{* * *} \\
(0.01)\end{array}$ \\
\hline $33-37$ & $\begin{array}{l}1.17^{* * *} \\
(0.02)\end{array}$ & $\begin{array}{l}0.82^{* * *} \\
(0.01)\end{array}$ & $\begin{array}{l}2.54^{* * *} \\
(0.02)\end{array}$ & $\begin{array}{l}2.23^{* * *} \\
(0.04)\end{array}$ & $\begin{array}{l}2.27^{* * *} \\
(0.04)\end{array}$ & $\begin{array}{l}2.18^{* * *} \\
(0.04)\end{array}$ & $\begin{array}{l}1.28^{* * *} \\
(0.01)\end{array}$ \\
\hline $38-45$ & $\begin{array}{l}1.33^{* * *} \\
(0.02)\end{array}$ & $\begin{array}{l}0.75^{* * *} \\
(0.01)\end{array}$ & $\begin{array}{l}2.59^{* * *} \\
(0.02)\end{array}$ & $\begin{array}{l}2.13^{* * *} \\
(0.04)\end{array}$ & $\begin{array}{l}2.19^{* * *} \\
(0.04)\end{array}$ & $\begin{array}{l}2.08^{* * *} \\
(0.04)\end{array}$ & $\begin{array}{l}1.19^{* * *} \\
(0.01)\end{array}$ \\
\hline \multicolumn{8}{|l|}{ Education } \\
\hline VT & $\begin{array}{l}0.01^{* *} \\
(0.00)\end{array}$ & & $\begin{array}{l}-0.06^{* *} \\
(0.03)\end{array}$ & $\begin{array}{l}0.00 \\
(0.00)\end{array}$ & $\begin{array}{l}0.04 \\
(0.05)\end{array}$ & $\begin{array}{l}0.06 \\
(0.05)\end{array}$ & $\begin{array}{l}-0.08^{* * *} \\
(0.01)\end{array}$ \\
\hline $\mathrm{TE}$ & $\begin{array}{l}-0.06^{* * *} \\
(0.00)\end{array}$ & & $\begin{array}{l}-2.09^{* * *} \\
(0.05)\end{array}$ & $\begin{array}{l}-0.00 \\
(0.00)\end{array}$ & $\begin{array}{l}-2.05^{* * *} \\
(0.09)\end{array}$ & $\begin{array}{l}-1.98^{* * *} \\
(0.09)\end{array}$ & $\begin{array}{l}-0.19^{* * *} \\
(0.01)\end{array}$ \\
\hline \multicolumn{8}{|c|}{ Education $\times$ Age } \\
\hline $\mathrm{VT} \times 23-27$ & $\begin{array}{l}-0.01 \\
(0.01)\end{array}$ & $\begin{array}{l}-0.08^{* * *} \\
(0.01)\end{array}$ & $\begin{array}{l}0.03 \\
(0.03)\end{array}$ & $\begin{array}{l}-0.14^{* * *} \\
(0.04)\end{array}$ & $\begin{array}{l}-0.07^{*} \\
(0.04)\end{array}$ & $\begin{array}{c}-0.07^{*} \\
(0.04)\end{array}$ & \\
\hline $\mathrm{TE} \times 23-27$ & $\begin{array}{l}-0.19^{* * *} \\
(0.01)\end{array}$ & $\begin{array}{l}-0.21^{* * *} \\
(0.01)\end{array}$ & $\begin{array}{l}1.11^{* * *} \\
(0.05)\end{array}$ & $\begin{array}{l}1.03^{* * *} \\
(0.07)\end{array}$ & $\begin{array}{l}1.05^{* * *} \\
(0.09)\end{array}$ & $\begin{array}{l}1.06^{* * *} \\
(0.09)\end{array}$ & \\
\hline $\mathrm{VT} \times 28-32$ & $\begin{array}{l}-0.02^{*} \\
(0.01)\end{array}$ & $\begin{array}{l}-0.16^{* * *} \\
(0.01)\end{array}$ & $\begin{array}{l}0.05^{*} \\
(0.03)\end{array}$ & $\begin{array}{l}-0.24^{* * *} \\
(0.04)\end{array}$ & $\begin{array}{l}-0.13^{* * *} \\
(0.04)\end{array}$ & $\begin{array}{l}-0.12^{* * *} \\
(0.04)\end{array}$ & \\
\hline $\mathrm{TE} \times 28-32$ & $\begin{array}{l}-0.23^{* * *} \\
(0.01)\end{array}$ & $\begin{array}{l}-0.25^{* * *} \\
(0.01)\end{array}$ & $\begin{array}{l}1.77^{* * *} \\
(0.05)\end{array}$ & $\begin{array}{l}1.62^{* * *} \\
(0.08)\end{array}$ & $\begin{array}{l}1.65^{* * *} \\
(0.09)\end{array}$ & $\begin{array}{l}1.66^{* * *} \\
(0.09)\end{array}$ & \\
\hline $\mathrm{VT} \times 33-38$ & $\begin{array}{l}-0.03^{* *} \\
(0.01)\end{array}$ & $\begin{array}{l}-0.21^{* * *} \\
(0.02)\end{array}$ & $\begin{array}{l}0.05^{* *} \\
(0.03)\end{array}$ & $\begin{array}{l}-0.28^{* * *} \\
(0.04)\end{array}$ & $\begin{array}{l}-0.16^{* * *} \\
(0.04)\end{array}$ & $\begin{array}{l}-0.15^{* * *} \\
(0.04)\end{array}$ & \\
\hline $\mathrm{TE} \times 33-38$ & $\begin{array}{l}-0.12^{* * *} \\
(0.02)\end{array}$ & $\begin{array}{l}-0.14^{* * *} \\
(0.02)\end{array}$ & $\begin{array}{l}1.99 * * * \\
(0.05)\end{array}$ & $\begin{array}{l}1.81^{* * *} \\
(0.08)\end{array}$ & $\begin{array}{l}1.85^{* * *} \\
(0.09)\end{array}$ & $\begin{array}{l}1.86^{* * *} \\
(0.09)\end{array}$ & \\
\hline $\mathrm{VT} \times 38-45$ & $\begin{array}{l}-0.09^{* * *} \\
(0.02)\end{array}$ & $\begin{array}{l}-0.21^{* * *} \\
(0.02)\end{array}$ & $\begin{array}{l}0.03 \\
(0.03)\end{array}$ & $\begin{array}{l}-0.28^{* * *} \\
(0.04)\end{array}$ & $\begin{array}{l}-0.15^{* * *} \\
(0.04)\end{array}$ & $\begin{array}{l}-0.14^{* * *} \\
(0.04)\end{array}$ & \\
\hline $\mathrm{TE} \times 38-45$ & $\begin{array}{l}-0.09^{* * *} \\
(0.02)\end{array}$ & $\begin{array}{l}-0.05^{* * *} \\
(0.02)\end{array}$ & $\begin{array}{l}2.04^{* * *} \\
(0.05)\end{array}$ & $\begin{array}{l}1.87^{* * *} \\
(0.08)\end{array}$ & $\begin{array}{l}1.92^{* * *} \\
(0.09)\end{array}$ & $\begin{array}{l}1.92^{* * *} \\
(0.09)\end{array}$ & \\
\hline Employment & & & & & & & \\
\hline Part-time & $\begin{array}{l}0.17^{* * *} \\
(0.01)\end{array}$ & $\begin{array}{l}0.05^{* * *} \\
(0.00)\end{array}$ & $\begin{array}{l}0.16^{* * *} \\
(0.00)\end{array}$ & $\begin{array}{l}0.07^{* * *} \\
(0.00)\end{array}$ & $\begin{array}{l}0.08^{* * *} \\
(0.00)\end{array}$ & $\begin{array}{l}0.07^{* * *} \\
(0.00)\end{array}$ & $\begin{array}{l}0.05^{* * *} \\
(0.00)\end{array}$ \\
\hline Full-time & $\begin{array}{l}-0.10^{* * *} \\
(0.01)\end{array}$ & $\begin{array}{l}-0.05^{* * *} \\
(0.00)\end{array}$ & $\begin{array}{l}-0.06^{* * *} \\
(0.00)\end{array}$ & $\begin{array}{l}0.03^{* * *} \\
(0.00)\end{array}$ & $\begin{array}{l}0.03^{* * *} \\
(0.00)\end{array}$ & $\begin{array}{l}0.03^{* * *} \\
(0.00)\end{array}$ & $\begin{array}{l}-0.02^{* * *} \\
(0.00)\end{array}$ \\
\hline Past Employ & & & & & & & \\
\hline
\end{tabular}

Continued on next page 


\begin{tabular}{|c|c|c|c|c|c|c|c|}
\hline & \multicolumn{2}{|c|}{ Linear } & \multicolumn{5}{|c|}{ Poisson } \\
\hline & OLS & $\mathrm{FE}$ & Pooled & $\mathrm{FE}$ & $\mathrm{RE}$ & $\mathrm{CRE}$ & CRE-ME \\
\hline Not empl. & $\begin{array}{l}0.01^{* * *} \\
(0.00)\end{array}$ & $\begin{array}{l}0.01^{* * *} \\
(0.00)\end{array}$ & $\begin{array}{l}-0.00 \\
(0.00)\end{array}$ & $\begin{array}{l}-0.02^{* * *} \\
(0.00)\end{array}$ & $\begin{array}{l}-0.02^{* * *} \\
(0.00)\end{array}$ & $\begin{array}{l}-0.02^{* * *} \\
(0.00)\end{array}$ & $\begin{array}{l}-0.03^{* * *} \\
(0.00)\end{array}$ \\
\hline \multicolumn{8}{|l|}{ Wage } \\
\hline $25-49 \%$ & $\begin{array}{l}-0.01^{*} \\
(0.01)\end{array}$ & $\begin{array}{l}-0.02^{* * *} \\
(0.00)\end{array}$ & $\begin{array}{l}-0.03^{* * *} \\
(0.00)\end{array}$ & $\begin{array}{l}-0.04^{* * *} \\
(0.00)\end{array}$ & $\begin{array}{l}-0.04^{* * *} \\
(0.00)\end{array}$ & $\begin{array}{l}-0.04^{* * *} \\
(0.00)\end{array}$ & $\begin{array}{l}-0.05^{* * *} \\
(0.00)\end{array}$ \\
\hline $50-74 \%$ & $\begin{array}{l}-0.08^{* * *} \\
(0.01)\end{array}$ & $\begin{array}{l}-0.04^{* * *} \\
(0.00)\end{array}$ & $\begin{array}{l}-0.08^{* * *} \\
(0.00)\end{array}$ & $\begin{array}{l}-0.05^{* * *} \\
(0.00)\end{array}$ & $\begin{array}{l}-0.06^{* * *} \\
(0.00)\end{array}$ & $\begin{array}{l}-0.05^{* * *} \\
(0.00)\end{array}$ & $\begin{array}{l}-0.07^{* * *} \\
(0.00)\end{array}$ \\
\hline $75-89 \%$ & $\begin{array}{l}-0.13^{* * *} \\
(0.01)\end{array}$ & $\begin{array}{l}-0.06^{* * *} \\
(0.00)\end{array}$ & $\begin{array}{l}-0.11^{* * *} \\
(0.00)\end{array}$ & $\begin{array}{l}-0.05^{* * *} \\
(0.00)\end{array}$ & $\begin{array}{l}-0.07^{* * *} \\
(0.00)\end{array}$ & $\begin{array}{l}-0.05^{* * *} \\
(0.00)\end{array}$ & $\begin{array}{l}-0.07^{* * *} \\
(0.00)\end{array}$ \\
\hline $90-94 \%$ & $\begin{array}{l}-0.19^{* * *} \\
(0.01)\end{array}$ & $\begin{array}{l}-0.09^{* * *} \\
(0.00)\end{array}$ & $\begin{array}{l}-0.16^{* * *} \\
(0.01)\end{array}$ & $\begin{array}{l}-0.05^{* * *} \\
(0.00)\end{array}$ & $\begin{array}{l}-0.08^{* * *} \\
(0.00)\end{array}$ & $\begin{array}{l}-0.05^{* * *} \\
(0.00)\end{array}$ & $\begin{array}{l}-0.08^{* * *} \\
(0.01)\end{array}$ \\
\hline $95-98 \%$ & $\begin{array}{l}-0.21^{* * *} \\
(0.01)\end{array}$ & $\begin{array}{l}-0.08^{* * *} \\
(0.01)\end{array}$ & $\begin{array}{l}-0.16^{* * *} \\
(0.01)\end{array}$ & $\begin{array}{l}-0.02^{* * *} \\
(0.00)\end{array}$ & $\begin{array}{l}-0.05^{* * *} \\
(0.00)\end{array}$ & $\begin{array}{l}-0.02^{* * *} \\
(0.01)\end{array}$ & $\begin{array}{l}-0.05^{* * *} \\
(0.01)\end{array}$ \\
\hline $99-100 \%$ & $\begin{array}{l}-0.18^{* * *} \\
(0.03)\end{array}$ & $\begin{array}{l}-0.04^{* * *} \\
(0.01)\end{array}$ & $\begin{array}{l}-0.12^{* * *} \\
(0.01)\end{array}$ & $\begin{array}{l}0.01 \\
(0.01)\end{array}$ & $\begin{array}{c}-0.02^{*} \\
(0.01)\end{array}$ & $\begin{array}{l}0.02^{* *} \\
(0.01)\end{array}$ & $\begin{array}{l}-0.01 \\
(0.01)\end{array}$ \\
\hline \multicolumn{8}{|c|}{ Wage Increase } \\
\hline$>0$ & $\begin{array}{l}-0.03^{* * *} \\
(0.00)\end{array}$ & $\begin{array}{l}-0.03^{* * *} \\
(0.00)\end{array}$ & $\begin{array}{l}-0.04^{* * *} \\
(0.00)\end{array}$ & $\begin{array}{l}-0.05^{* * *} \\
(0.00)\end{array}$ & $\begin{array}{l}-0.05^{* * *} \\
(0.00)\end{array}$ & $\begin{array}{l}-0.05^{* * *} \\
(0.00)\end{array}$ & $\begin{array}{l}-0.09^{* * *} \\
(0.00)\end{array}$ \\
\hline median & $\begin{array}{l}0.02^{* * *} \\
(0.00)\end{array}$ & $\begin{array}{l}0.01^{* * * *} \\
(0.00)\end{array}$ & $\begin{array}{l}0.04^{* * *} \\
(0.00)\end{array}$ & $\begin{array}{l}0.01^{* * *} \\
(0.00)\end{array}$ & $\begin{array}{l}0.02^{* * *} \\
(0.00)\end{array}$ & $\begin{array}{l}0.02^{* * *} \\
(0.00)\end{array}$ & $\begin{array}{l}-0.05^{* * *} \\
(0.00)\end{array}$ \\
\hline \multicolumn{8}{|c|}{ Tenure in months } \\
\hline $6-11$ & $\begin{array}{l}0.00 \\
(0.00)\end{array}$ & $\begin{array}{l}-0.02^{* * *} \\
(0.00)\end{array}$ & $\begin{array}{l}-0.01^{* * *} \\
(0.01)\end{array}$ & $\begin{array}{l}-0.02^{* * *} \\
(0.00)\end{array}$ & $\begin{array}{l}-0.02^{* * *} \\
(0.00)\end{array}$ & $\begin{array}{l}-0.02^{* * *} \\
(0.00)\end{array}$ & $\begin{array}{l}-0.02^{* * *} \\
(0.00)\end{array}$ \\
\hline $12-23$ & $\begin{array}{l}0.06^{* * *} \\
(0.00)\end{array}$ & $\begin{array}{l}0.04^{* * *} \\
(0.00)\end{array}$ & $\begin{array}{l}0.05^{* * *} \\
(0.00)\end{array}$ & $\begin{array}{l}0.01^{* * * *} \\
(0.00)\end{array}$ & $\begin{array}{l}0.01^{* * *} \\
(0.00)\end{array}$ & $\begin{array}{l}0.01^{* * * *} \\
(0.00)\end{array}$ & $\begin{array}{l}0.03^{* * *} \\
(0.00)\end{array}$ \\
\hline $24-35$ & $\begin{array}{l}0.06^{* * *} \\
(0.00)\end{array}$ & $\begin{array}{l}0.03^{* * *} \\
(0.00)\end{array}$ & $\begin{array}{l}0.07^{* * *} \\
(0.00)\end{array}$ & $\begin{array}{l}0.03^{* * *} \\
(0.00)\end{array}$ & $\begin{array}{l}0.04^{* * *} \\
(0.00)\end{array}$ & $\begin{array}{l}0.03^{* * *} \\
(0.00)\end{array}$ & $\begin{array}{l}0.06^{* * *} \\
(0.00)\end{array}$ \\
\hline$\geq 36$ & $\begin{array}{l}0.07^{* * *} \\
(0.01)\end{array}$ & $\begin{array}{l}0.03^{* * *} \\
(0.00)\end{array}$ & $\begin{array}{l}0.10^{* * *} \\
(0.00)\end{array}$ & $\begin{array}{l}0.06^{* * *} \\
(0.00)\end{array}$ & $\begin{array}{l}0.07^{* * *} \\
(0.00)\end{array}$ & $\begin{array}{l}0.07^{* * *} \\
(0.00)\end{array}$ & $\begin{array}{l}0.10^{* * *} \\
(0.00)\end{array}$ \\
\hline \multicolumn{8}{|c|}{ Occupational Choice } \\
\hline Teacher & $\begin{array}{l}-0.09^{* * *} \\
(0.02)\end{array}$ & $\begin{array}{l}-0.01 \\
(0.01)\end{array}$ & $\begin{array}{l}-0.08^{* * *} \\
(0.01)\end{array}$ & $\begin{array}{l}0.03^{* * *} \\
(0.01)\end{array}$ & $\begin{array}{l}0.00 \\
(0.01)\end{array}$ & $\begin{array}{l}-0.03^{* * *} \\
(0.01)\end{array}$ & $\begin{array}{l}-0.03^{* * *} \\
(0.01)\end{array}$ \\
\hline Cohort & & & & & & & \\
\hline $1959-68$ & $\begin{array}{l}-0.08^{* * *} \\
(0.01)\end{array}$ & & $\begin{array}{l}-0.05^{* * *} \\
(0.00)\end{array}$ & $\begin{array}{l}0.00 \\
(0.00)\end{array}$ & $\begin{array}{l}-0.13^{* * *} \\
(0.01)\end{array}$ & $\begin{array}{l}0.02^{* * *} \\
(0.01)\end{array}$ & $\begin{array}{l}0.03^{* *} \\
(0.01)\end{array}$ \\
\hline 1969-78 & $\begin{array}{l}-0.27^{* * *} \\
(0.02)\end{array}$ & & $\begin{array}{l}-0.22^{* * *} \\
(0.01)\end{array}$ & $\begin{array}{l}0.00 \\
(0.00)\end{array}$ & $\begin{array}{l}-0.53^{* * *} \\
(0.01)\end{array}$ & $\begin{array}{l}0.07^{* * *} \\
(0.02)\end{array}$ & $\begin{array}{l}0.08^{* * *} \\
(0.02)\end{array}$ \\
\hline 1979-89 & $\begin{array}{l}-0.34^{* * *} \\
(0.02)\end{array}$ & & $\begin{array}{l}-0.48^{* * *} \\
(0.01)\end{array}$ & $\begin{array}{l}-0.00^{* *} \\
(0.00)\end{array}$ & $\begin{array}{l}-1.01^{* * *} \\
(0.02)\end{array}$ & $\begin{array}{l}-0.07^{* *} \\
(0.03)\end{array}$ & $\begin{array}{l}-0.07^{*} \\
(0.03)\end{array}$ \\
\hline
\end{tabular}

Continued on next page 


\begin{tabular}{|c|c|c|c|c|c|c|c|}
\hline & \multicolumn{2}{|c|}{ Linear } & \multicolumn{5}{|c|}{ Poisson } \\
\hline & OLS & $\mathrm{FE}$ & Pooled & $\mathrm{FE}$ & $\mathrm{RE}$ & $\mathrm{CRE}$ & CRE-ME \\
\hline \multicolumn{8}{|l|}{ Year } \\
\hline 1997-1999 & $\begin{array}{l}0.02^{* * *} \\
(0.00)\end{array}$ & $\begin{array}{l}0.10^{* * *} \\
(0.00)\end{array}$ & $\begin{array}{l}0.00 \\
(0.00)\end{array}$ & $\begin{array}{l}0.06^{* * *} \\
(0.00)\end{array}$ & $\begin{array}{l}0.05^{* * *} \\
(0.00)\end{array}$ & $\begin{array}{l}0.06^{* * *} \\
(0.00)\end{array}$ & $\begin{array}{l}0.06^{* * *} \\
(0.00)\end{array}$ \\
\hline 2000-2002 & $\begin{array}{l}0.07^{* * *} \\
(0.00)\end{array}$ & $\begin{array}{l}0.22^{* * *} \\
(0.00)\end{array}$ & $\begin{array}{l}0.04^{* * *} \\
(0.00)\end{array}$ & $\begin{array}{l}0.16^{* * *} \\
(0.00)\end{array}$ & $\begin{array}{l}0.14^{* * *} \\
(0.00)\end{array}$ & $\begin{array}{l}0.16^{* * *} \\
(0.00)\end{array}$ & $\begin{array}{l}0.16^{* * *} \\
(0.00)\end{array}$ \\
\hline 2003-2005 & $\begin{array}{l}0.12^{* * *} \\
(0.01)\end{array}$ & $\begin{array}{l}0.35^{* * *} \\
(0.00)\end{array}$ & $\begin{array}{l}0.11^{* * *} \\
(0.00)\end{array}$ & $\begin{array}{l}0.27^{* * *} \\
(0.00)\end{array}$ & $\begin{array}{l}0.24^{* * *} \\
(0.00)\end{array}$ & $\begin{array}{l}0.27^{* * *} \\
(0.00)\end{array}$ & $\begin{array}{l}0.29^{* * *} \\
(0.00)\end{array}$ \\
\hline 2006-2007 & $\begin{array}{l}0.14^{* * *} \\
(0.01)\end{array}$ & $\begin{array}{l}0.45^{* * *} \\
(0.00)\end{array}$ & $\begin{array}{l}0.13^{* * *} \\
(0.00)\end{array}$ & $\begin{array}{l}0.36^{* * *} \\
(0.00)\end{array}$ & $\begin{array}{l}0.32^{* * *} \\
(0.00)\end{array}$ & $\begin{array}{l}0.36^{* * *} \\
(0.00)\end{array}$ & $\begin{array}{l}0.40^{* * *} \\
(0.00)\end{array}$ \\
\hline \multicolumn{8}{|c|}{ Regressors specific for France } \\
\hline Married & $\begin{array}{l}0.58^{* * *} \\
(0.01)\end{array}$ & $\begin{array}{l}0.42^{* * *} \\
(0.01)\end{array}$ & $\begin{array}{l}0.45^{* * *} \\
(0.00)\end{array}$ & $\begin{array}{l}0.46^{* * *} \\
(0.01)\end{array}$ & $\begin{array}{l}0.51^{* * *} \\
(0.01)\end{array}$ & $\begin{array}{l}0.48^{* * *} \\
(0.01)\end{array}$ & $\begin{array}{l}0.52^{* * *} \\
(0.01)\end{array}$ \\
\hline Île-de-France & $\begin{array}{l}-0.06^{* * *} \\
(0.01)\end{array}$ & $\begin{array}{l}-0.05^{* * *} \\
(0.01)\end{array}$ & $\begin{array}{l}-0.06^{* * *} \\
(0.00)\end{array}$ & $\begin{array}{l}-0.03^{* * *} \\
(0.01)\end{array}$ & $\begin{array}{l}-0.07^{* * *} \\
(0.01)\end{array}$ & $\begin{array}{l}-0.05^{* * *} \\
(0.01)\end{array}$ & $\begin{array}{l}-0.05^{* * *} \\
(0.01)\end{array}$ \\
\hline Overseas & $\begin{array}{l}-0.35^{* * *} \\
(0.02)\end{array}$ & & $\begin{array}{l}-0.43^{* * *} \\
(0.01)\end{array}$ & $\begin{array}{l}0.00 \\
(0.00)\end{array}$ & $\begin{array}{l}-0.39^{* * *} \\
(0.03)\end{array}$ & $\begin{array}{l}-0.40^{* * *} \\
(0.03)\end{array}$ & $\begin{array}{l}-0.36^{* * *} \\
(0.02)\end{array}$ \\
\hline \multicolumn{8}{|c|}{ Averages of time-varying covariates } \\
\hline$\overline{\mathrm{Age}_{i}}$ & & & & & & $\begin{array}{l}0.29^{* * *} \\
(0.01)\end{array}$ & \\
\hline$\overline{\text { Wage }_{i}}$ & & & & & & $\begin{array}{l}-0.09^{* * *} \\
(0.00)\end{array}$ & \\
\hline$\overline{E m p l_{i}}$ & & & & & & $\begin{array}{l}-0.45^{* * *} \\
(0.02)\end{array}$ & \\
\hline$\overline{\Delta W a g e_{i}}$ & & & & & & $\begin{array}{l}-0.53^{* * *} \\
(0.02)\end{array}$ & \\
\hline$\overline{\text { Tenure }_{i}}$ & & & & & & $\begin{array}{l}0.13^{* * *} \\
(0.01)\end{array}$ & \\
\hline$\overline{\text { PastEmpl }_{i}}$ & & & & & & $\begin{array}{l}-0.17^{* * *} \\
(0.03)\end{array}$ & \\
\hline$\overline{\text { Married }_{i}}$ & & & & & & $\begin{array}{l}0.06^{* * *} \\
(0.01)\end{array}$ & \\
\hline $1 / \mathrm{A}$ & & & & & $\begin{array}{l}1.20^{(* * *)} \\
(0.01)\end{array}$ & $\begin{array}{l}1.16^{(* * *)} \\
(0.01)\end{array}$ & \\
\hline Constant & $\begin{array}{l}0.23^{* * *} \\
(0.02)\end{array}$ & $\begin{array}{l}0.29^{* * *} \\
(0.00)\end{array}$ & $\begin{array}{l}-2.31^{* * *} \\
(0.02)\end{array}$ & & $\begin{array}{l}-1.92^{\text {*** }} \\
(0.04)\end{array}$ & $\begin{array}{l}-2.14^{* * *} \\
(0.05)\end{array}$ & \\
\hline Observations & $1,135,772$ & $1,135,772$ & $1,135,772$ & 796,164 & $1,135,772$ & $1,135,772$ & \\
\hline RSS in 1,000 & 880 & 134 & & & & & \\
\hline LL in 1,000 & & & $-1,228$ & -694 & $-1,005$ & $-1,004$ & \\
\hline
\end{tabular}

Continued on next page 


\begin{tabular}{cc|ccccc}
\hline \hline & \multicolumn{3}{c}{ Linear } & \multicolumn{2}{c}{ Poisson } \\
OLS & FE & Pooled & FE & RE & CRE & CRE-ME \\
\hline \hline
\end{tabular}

Notes: ${ }^{*} p<0.05,{ }^{* *} p<0.01,{ }^{* * *} p<0.001$. Standard errors based on 100 bootstrap replications (this value was chosen due to very long computing times). Controlling for twins and multiples. ${ }^{(* * *)}$ LR test of $\mathrm{H}_{0}: 1 / \mathrm{A}=0$ is rejected at a significance level $<0.001$.

Coefficients specific to Germany reveal important differences between females who lived in the former GDR and females raised in former West Germany, with these differences varying over cohorts. The estimates of federal state dummies are significant but do not differ largely in their size. The coefficients of interest discussed in Section 6 are found to be robust to the inclusion of further country-specific variables. The wage effect and the education effect even increase in size, such that the difference in opportunity costs between France and Germany become even more pronounced.

The French baseline parameter estimates of interest are completely robust to additional control variables. This merits attention because for France a binary variable indicating the marital status is included. As expected, being married increases the number of children considerably by 0.52 children. Even though this variable does not capture employment or income of the partner, nor if the partner is living in the same household, the unchanged coefficients suggest that the omission of marriage in the baseline regression does not induce a bias. Living in proximity to Paris reduces the number of children compared to all other departments significantly by 0.05 children. Interestingly, there is a large negative impact of being born overseas (-0.36 children), suggesting that French mainland attitudes and French mainland socio-cultural conventions do affect fertility.

\section{Additional References}

[1] Adda, J., Dustmann, C., Stevens, K. (2017). The career costs of children. Journal of Political Economy, 125(2), 293-337.

[2] Arntz, M., Dlugosz, S., Wilke, R. A. (2017). The sorting of female careers after first birth: a competing risks analysis of maternity leave duration. Oxford Bulletin of Economics and Statistics, 79(5), 689-716. 
[3] Becker, G. S., Lewis, H. G. (1973). On the Interaction between the Quantity and Quality of Children. Journal of Political Economy, 81(2), S279-S288.

[4] Duesenberry, J. S. (1960). Comment on Becker, G. S. (1960). An economic analysis of fertility. In: Demographic and Economic Change in Developed Countries, 231-234. Columbia University Press.

[5] Francesconi, M. (2002). A joint dynamic model of fertility and work of married women. Journal of Labor Economics, 20(2), 336-380.

[6] Sobotka, T., Beaujouan, E. (2014). Two Is best? The persistence of a two-child family ideal in Europe. Population and Development Review, 40(3), 391-419.

[7] Willis, R. J. (1973). A new approach to the economic theory of fertility behavior. Journal of Political Economy, 81(2), S14-S64. 